Prepared in cooperation with the New York State Department of Environmental Conservation

\title{
Statewide Assessment of Karst Aquifers in New York With an Inventory of Closed-Depression and Focused-Recharge Features
}

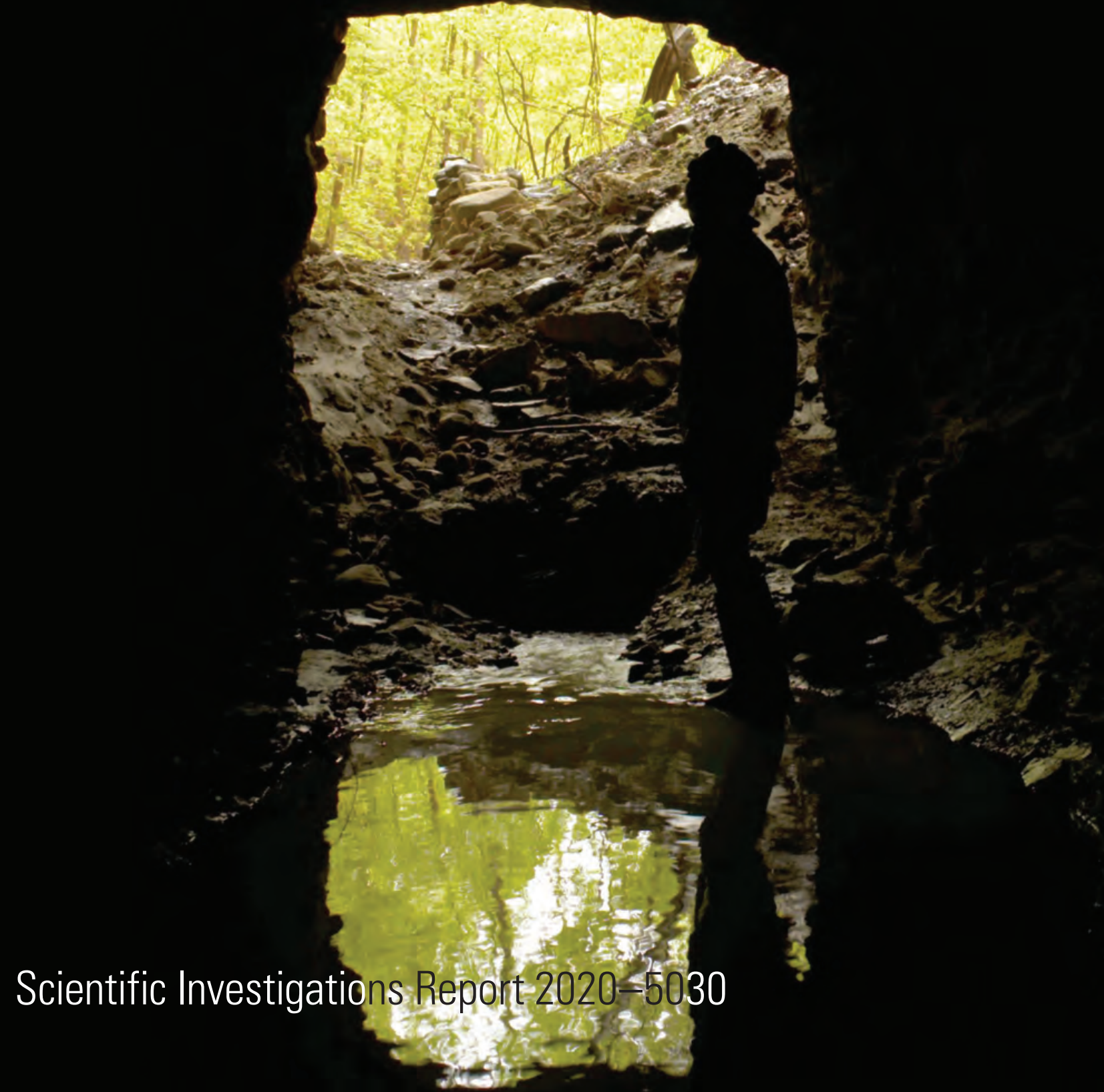

U.S. Department of the Interior

U.S. Geological Survey 
Cover. Front. Entrance to Schoharie Caverns in Schoharie County, New York. Entrance is in the Manlius Limestone near the top of a steep slope. The spring at the cave opening is perched high above nearby creek.

Back. Photograph of a cave passage from McFail's Cave. Photograph by Art Palmer, professor emeritus, State University of New York at Oneonta, New York. 


\section{Statewide Assessment of Karst Aquifers in New York With an Inventory of Closed-Depression and Focused-Recharge Features}

By William M. Kappel, James E. Reddy, and Jonathan C. Root

Prepared in cooperation with the New York State Department of Environmental

Conservation

Scientific Investigations Report 2020-5030 


\title{
U.S. Department of the Interior \\ DAVID BERNHARDT, Secretary
}

\author{
U.S. Geological Survey \\ James F. Reilly II, Director
}

U.S. Geological Survey, Reston, Virginia: 2020

For more information on the USGS - the Federal source for science about the Earth, its natural and living resources, natural hazards, and the environment—visit https://www.usgs.gov or call 1-888-ASK-USGS.

For an overview of USGS information products, including maps, imagery, and publications, visit https://store.usgs.gov/.

Any use of trade, firm, or product names is for descriptive purposes only and does not imply endorsement by the U.S. Government.

Although this information product, for the most part, is in the public domain, it also may contain copyrighted materials as noted in the text. Permission to reproduce copyrighted items must be secured from the copyright owner.

Suggested citation:

Kappel, W.M., Reddy, J.E., and Root, J.C., 2020, Statewide assessment of karst aquifers in New York with an inventory of closed-depression and focused-recharge features: U.S. Geological Survey Scientific Investigations Report 2020-5030, 74 p., https://doi.org/10.3133/sir20205030.

Data associated with this publication:

Reddy, J.E., Kappel, W.M., and Root, J.C., 2020, Data for statewide assessment of New York's karst aquifers with an inventory of closed-depression and focused-recharge features: U.S. Geological Survey data release, https://doi.org/10.5066/P9HGN5IJ.

ISSN 2328-0328 (online) 


\section{Acknowledgments}

The New York State Department of Health and individual county health departments provided information on numerous contamination events that were in karst areas. In a similar fashion, the New York State soil and water conservation districts provided data to assist in identifying where contamination issues in karst has occurred across the State.

The authors acknowledge Art Palmer, professor emeritus at State University of New York at Oneonta, who has shared his extensive knowledge of karst both in eastern New York and internationally. Thom Engel, trustee of the Northeastern Cave Conservancy and board member of the National Speleological Society, also shared his extensive knowledge of New York caves and karst. Albert Ash of the New York State Department of Environmental Conservation provided geographic information system (GIS) coverages of closed depressions from several counties in eastern New York. Paul Rubin of HydroQuest shared his knowledge of cave research in eastern and southeastern New York.

The authors also thank numerous local government agencies, public institutions, and individuals who shared their knowledge of specific karst features or information about such features from their office or personal files. Without these sources, illustrating the effects of karst on local and regional environmental scales throughout New York State would have been difficult. 



\section{Contents}

Acknowledgments ……...................................................................................................................

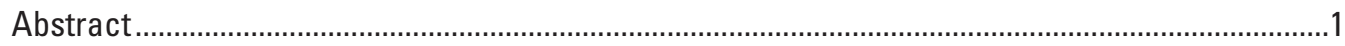

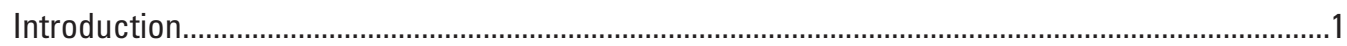

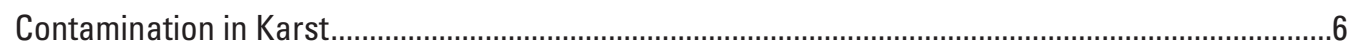

New York Bedrock as Affected by Karst and Glacial Processes in New York State .........................8

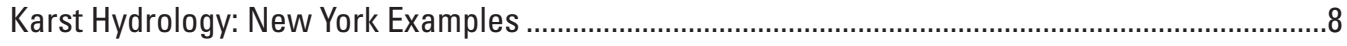

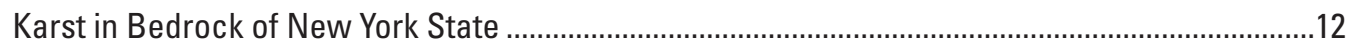

Western and Central New York ........................................................................................15

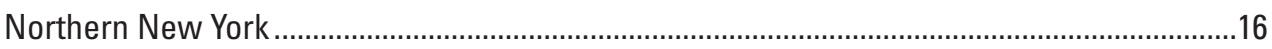

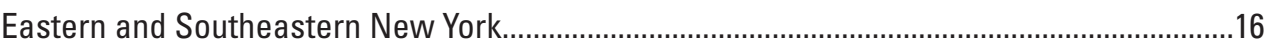

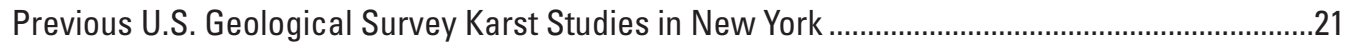

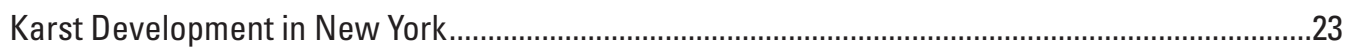

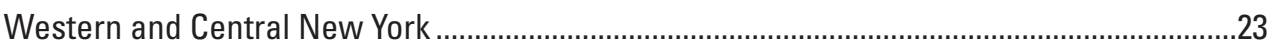

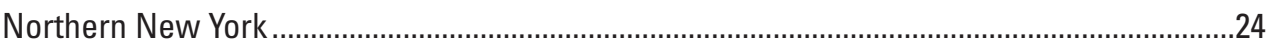

Eastern and Southeastern New York.............................................................................26

Closed-Depression and Focused-Recharge Inventory ............................................................29

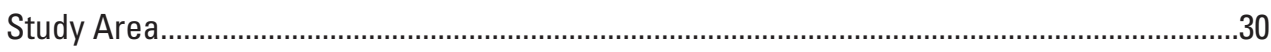

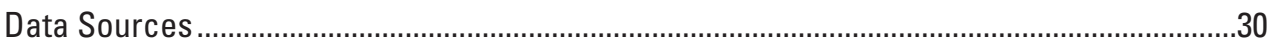

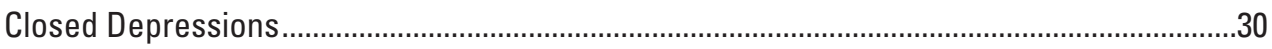

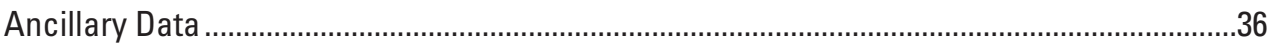

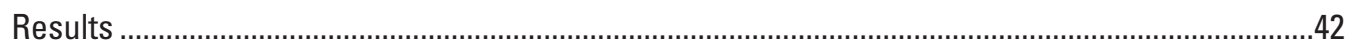

Summary

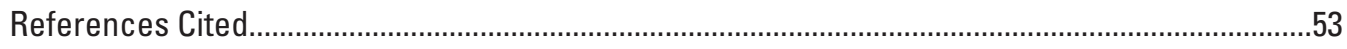

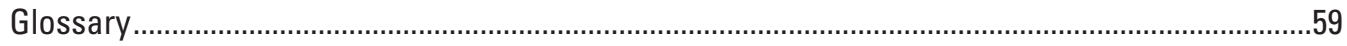

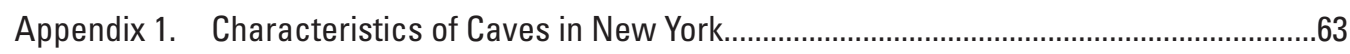

\section{Figures}

1. Map showing location of major geologic units where karst may develop in New

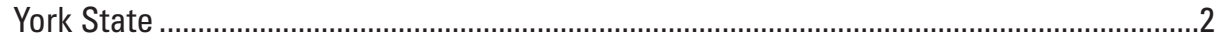

2. Photographs showing a small sinkhole-swallet in Genesee County, New York................3

3. Map and images showing a closed depression near Batavia, Genesee County,

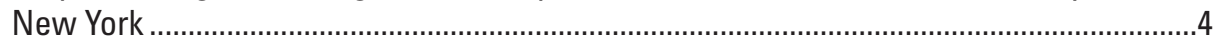

4. Images showing karst bedrock features in Madison County, New York ...........................5

5. Photographs showing swallet entrance to McFails Cave in Schoharie County,

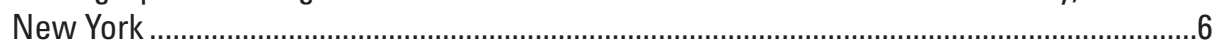

6. Map showing contamination issues in karst areas in New York........................................7

7. Graphs showing rainfall and a comparison of water levels for two wells between mid-September and mid-December 2016 in western New York ........................9

8. Aerial images showing a closed depression in Onondaga Limestone at the LeRoy Country Club in LeRoy, Genesee County, New York.

9. Photographs showing Disappearing Lake near Marcellus, Onondaga County, New York. 
10. Photographs showing a surface-water holding pond which has drained in Watertown, New York

11. Photographs showing karst features in the Rondout Valley, Ulster County, New York..14

12. Photographs showing glacial-related features common in Schoharie Creek Valley caves

13. Photographs showing dye trace in Black River Limestone, near Watertown, Jefferson County, New York.

14. Photographs showing cave passage features in Knox Cave in Albany County, New York

15. Photographs showing features in Knox Cave in Albany County, New York .....................19

16. Photographs of cave passages from Cobleskill Creek Valley in Schoharie County........20

17. Photographs showing the west side of the Hudson River Valley, New York...................21

18. Map and graphs showing water levels at Ellicott Creek, western New York ..................22

19. Photographs and cross section showing sinkhole development in evaporite karst bedrock in Syracuse, Onondaga County, New York ................................................25

20. Map showing locations of selected named cave systems in eastern New York ............27

21. Cross sections and photographs showing hydrogeologic conditions at Wawarsing, Ulster County, New York

22. Map showing closed depressions near Wheatland, New York......................................29

23. Map showing index of U.S. Geological Survey 7.5-minute quadrangle maps in New York

24. Maps showing closed depressions near Brantingham, Lewis County, New York ..........33

25. Maps showing examples of closed depressions not represented in digitization process of topographic maps for New York maps.

26. Map showing extent of lidar-derived digital elevation models within the karst aquifer study area in New York

27. Photographs showing identification of a closed depression near Argyle, Washington County, New York, with lidar-derived digital elevation models .36

28. Photographs showing identification of a closed depression near Ludlow Corners, Oneida County, New York, with lidar-derived digital elevation models .37

29. Map showing shale bedrock in New York that may contribute allogenic recharge to the adjacent carbonate-rock aquifer

30. Map showing distribution of closed depressions in the digital contour database .........43

31. Map showing distribution of closed depressions in New York in the digital raster graphic database

32. Map showing distribution of closed depressions in New York in the lidar database.....45

33. Map showing distribution of all closed depressions in New York ...................................46

34. Map showing concentration of closed depressions in New York by county ...................47

35. Map showing concentration of closed depressions in New York per square kilometer of study area for each county

36. Map showing bedrock geology of New York and distribution of closed depressions in New York

37. Map showing distribution of soils and closed depressions in New York

38. Map showing distribution of soil infiltration rate and closed depressions in New York

39. Map showing distribution of land cover and closed depressions in New York. 


\section{Tables}

1. Stratigraphic column of New York State bedrock indicating units in which karst features might be present...

2. Reclassified bedrock geologic units for karst aquifers in New York ...............................30

3. Sources for data acquired to conduct geographic information system analyses for karst aquifers in New York.

4. Classification scheme for light detection and ranging (lidar)-derived closed depressions in New York

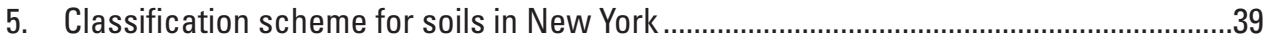

6. Classification scheme for soil infiltration rate in New York..............................................4

7. Land cover classifications for New York ......................................................................4

8. Closed depressions in New York, by data source ...........................................................42

\section{Conversion Factors}

U.S. customary units to International System of Units

\begin{tabular}{lll}
\hline \multicolumn{1}{c}{ Multiply } & \multicolumn{1}{c}{ By } & \multicolumn{1}{c}{ To obtain } \\
\hline inch (in.) & 2.54 & centimeter $(\mathrm{cm})$ \\
foot (ft) & 0.3048 & meter $(\mathrm{m})$ \\
mile (mi) & 1.609 & kilometer $(\mathrm{km})$ \\
yard (yd) & 0.9144 & meter (m) \\
acre & 0.4047 & hectare (ha) \\
square mile $\left(\mathrm{mi}^{2}\right)$ & 2.590 & square kilometer $\left(\mathrm{km}^{2}\right)$ \\
gallon (gal) & 3.785 & liter (L) \\
\hline
\end{tabular}

International System of Units to U.S. customary units

\begin{tabular}{lll}
\multicolumn{1}{c}{ Multiply } & By & \multicolumn{1}{c}{ To obtain } \\
\hline centimeter $(\mathrm{cm})$ & 0.3937 & inch (in.) \\
meter $(\mathrm{m})$ & 3.281 & foot (ft) \\
\hline
\end{tabular}

Temperature in degrees Celsius $\left({ }^{\circ} \mathrm{C}\right)$ may be converted to degrees Fahrenheit $\left({ }^{\circ} \mathrm{F}\right)$ as follows:

$$
{ }^{\circ} \mathrm{F}=\left(1.8 \times{ }^{\circ} \mathrm{C}\right)+32 \text {. }
$$

\section{Datum}

Vertical coordinate information is referenced to the North American Vertical Datum of 1988 (NAVD 88).

Horizontal coordinate information is referenced to the North American Datum of 1983 (NAD 83). Elevation, as used in this report, refers to distance above the vertical datum. 


\title{
Abbreviations
}

\author{
DEM digital elevation model \\ DRG digital raster graphic \\ E. coli Escherichia coli \\ GIS geographic information system \\ gSSURGO gridded Soil Survey Geographic database \\ lidar light detection and ranging \\ NHD National Hydrography Dataset \\ NLCD National Land Cover Database \\ NYSDEC New York State Department of Environmental Conservation \\ NYSDOH New York State Department of Health \\ SSURGO Soil Survey Geographic database \\ TCE trichloroethene \\ USGS U.S. Geological Survey
}




\title{
Statewide Assessment of Karst Aquifers in New York With an Inventory of Closed-Depression and Focused-Recharge Features
}

\author{
By William M. Kappel, James E. Reddy, and Jonathan C. Root
}

\section{Abstract}

Karst is a landscape formed from the dissolution of soluble rock or rock containing minerals that are easily dissolved from within the rock. The landscape is characterized by sinkholes, caves, losing streams, springs, and underground drainage systems, which rapidly move water through the karst. The two forms of karst in New York State include carbonate karst, which forms in carbonate rock (limestone, marble, and dolostone), and evaporite karst, which forms in rock that contains the evaporite minerals gypsum and halite.

Past and recent studies of karst across the State have shown that areas of focused recharge in karstic carbonate rock allow contaminants to enter aquifer systems with little attenuation. Focused areas of recharge need to be identified to help prevent such contamination from sources on or adjacent to the karst. The New York State Departments of Environmental Conservation and Health are collaborating with the agricultural community to make farmers and farmplanning advisors more aware of karst and how to manage daily farming activities to reduce their impact on surface water and groundwater resources, especially in karst areas. There is also a need to make regulators, planners, and the general public aware of New York's karst resources and to properly protect and manage these resources to protect the quality of groundwater and surface water that can flow into, through, and from karst bedrock.

Using publicly available geospatial data, karst bedrock and closed depressions over or near karst rock were identified across New York. Carbonate, evaporite, and marble geologic units were selected from a statewide 1:250,000-scale bedrock geology dataset. The selected geologic units were intersected with 7.5-minute quadrangle maps to define the study area.

The U.S. Geological Survey has compiled an inventory of closed depressions from statewide digital contour data, scanned 7.5-minute topographic maps known as a digital raster graphics, and light detection and ranging (lidar) digital elevation models. Analysis of the data resulted in the identification of 5,023 closed depressions statewide. The inventory was conducted to eliminate duplication of results from analysis of the three data sources. A series of overlay analyses was conducted using the closed depressions and thematic data known to be key factors in determining the probability of a closed depression contributing to focused groundwater recharge; the thematic data include bedrock geology, soil type, soil infiltration rate, and land cover.

Though the extent of karst development is important in understanding the interaction between surface water and groundwater in karst terrains, some of the worst cases of groundwater contamination in karst can occur where only minor karst features might be present. The presence of karstbe it a short section of a solutioned fracture or an extensive cave system - requires careful consideration, forward-looking environmental planning, and consistent water-quality protection to preserve New York State's water resources.

\section{Introduction}

The New York State Department of Environmental Conservation (NYSDEC) and Department of Health (NYS$\mathrm{DOH})$ are concerned about groundwater ${ }^{1}$ contamination in the karst aquifers of New York State (fig. 1), especially relating to the unintended introduction of industrial contaminants (such as volatile organic compounds [VOCs]) or agricultural contaminants (such as liquid manure; Reddy and Kappel, 2010). The NYSDEC and NYSDOH have started collaborating with the agricultural community to make farmers and farm-planning advisors more aware of karst and how to manage daily farming activities to reduce their impact on surface water and groundwater resources, especially in karst areas. To this end, the U.S. Geological Survey (USGS) has compiled an inventory of closed depressions from statewide digital contour data, scanned 7.5-minute topographic maps known as a digital raster graphics, and light detection and ranging (lidar) digital elevation models. This report provides information on the location of karst bedrock and associated closed depressions

\footnotetext{
${ }^{1}$ Words that appear in bold typeface are defined in the glossary of this report.
} 


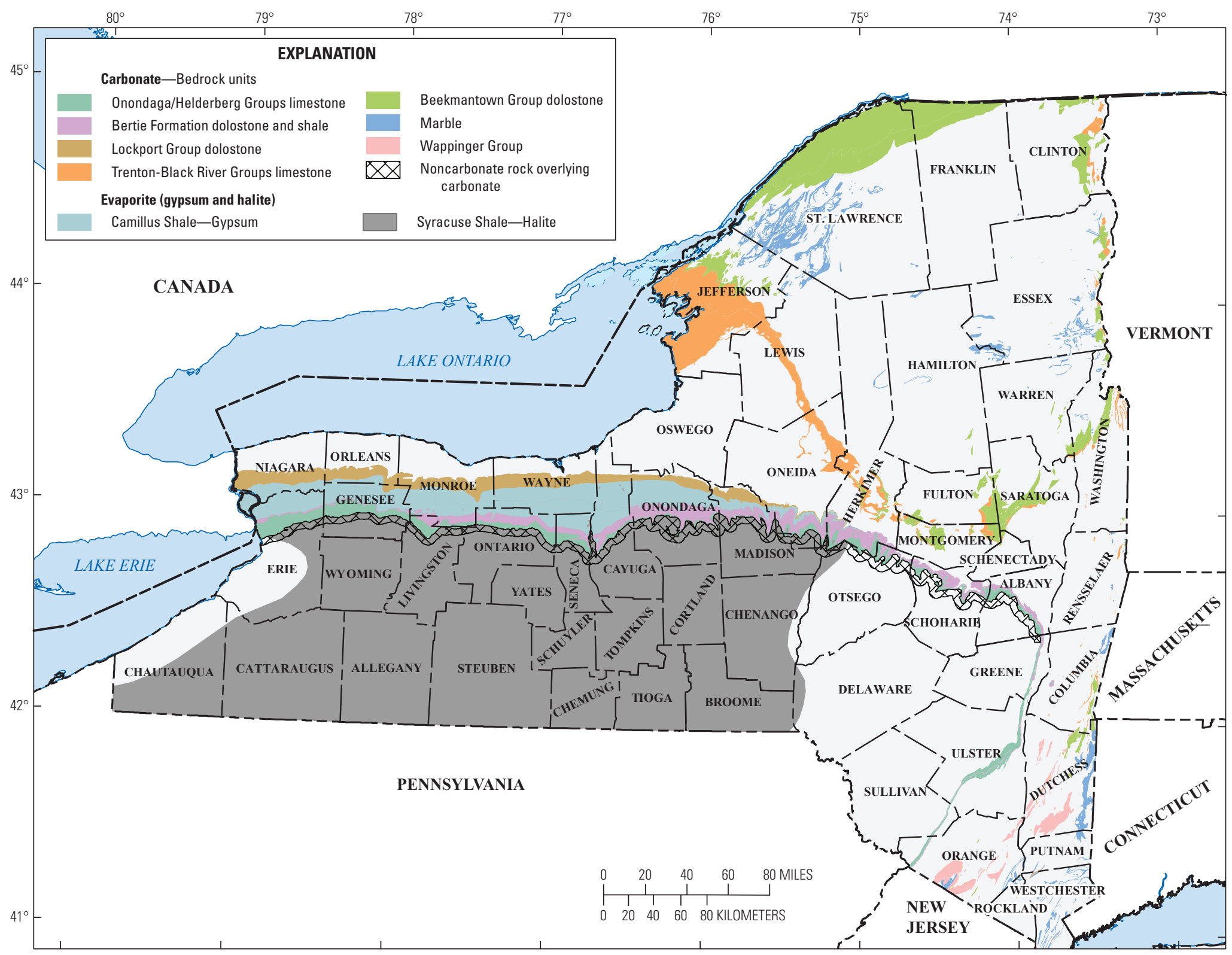

Figure 1. Major geologic units in which karst may be developed in New York State. 
that focus surface water recharge to groundwater in karst areas across New York. The report also provides examples of why it is important to carefully manage and protect this resource.

Karst development (karstification) forms highly permeable bedrock aquifers that transmit and yield water from solution-enlarged fractures, bedding planes, and other openings (Olcott, 1995). Karst is a landscape formed from the dissolution of soluble rock or rocks that contain minerals that are easily dissolved from within the rock. The landscape is characterized by sinkholes, caves, losing streams, springs, and underground drainage systems, which rapidly move water through the karst. The two most common types are karst that forms in carbonate rock, such as limestone, marble, and dolostone (carbonate karst), and karst that forms in rock that contains evaporite minerals, such as gypsum or halite (evaporite karst).

The potential for focused recharge in karst (figs. 2 through 5) is greatest where the rocks crop out at or near land surface and where closed depressions at the land surface can focus infiltration of surface-water runoff into the aquifer. Karst aquifers are recharged by direct infiltration of precipitation that falls on the karst landscape and by infiltration of surface runoff at closed depressions, sinkholes, and swallets. Surface runoff may include runoff from adjacent lowlands underlain by glaciolacustrine deposits or shale-bedrock uplands that are mantled with glacial till.

Evaporite deposits of gypsum and halite associated with some shales are the most soluble of the common rock types with solubilities at standard temperature ( 20 degrees Celsius) and atmospheric pressure ( 1 bar) of 2.5 grams per liter $(\mathrm{g} / \mathrm{L})$ for gypsum and $360 \mathrm{~g} / \mathrm{L}$ for halite. Karst features similar to those present in carbonate rock can develop in these evaporite deposits. The solubility of carbonate bedrock is $0.39 \mathrm{~g} / \mathrm{L}$ for dolostone and $0.0062 \mathrm{~g} / \mathrm{L}$ for limestone, making the rocks relatively insoluble in relation to evaporite deposits. A major difference between carbonate- and evaporite-rock karst is the time it takes for karst features to develop. Karst in carbonate rock develops over years, decades, or centuries, but karst in evaporite rock can develop over days, weeks, or years (Johnson, 2007). Gypsum deposits are more common than halite deposits and represent most evaporite-type karst in the United States (Dean and Johnson, 1989; Johnson, 2003). The solutioning of gypsum, where gypsum crops out at land surface or is within 100 feet (ft) of the land surface, can form karst features, but halite rarely appears at or near the land surface because it usually is dissolved at depths ranging from tens to hundreds of feet below the land surface (Johnson, 2007). Karst development in the carbonate rock of New York State is dependent on the rock type (limestone versus dolostone), rock structure (bedding dip and fracturing), and potential for focused recharge. Karst can develop in carbonate rock at any depth where favorable conditions are present and as long as there is a continuity of flow from where water enters and eventually exits the soluble rock.
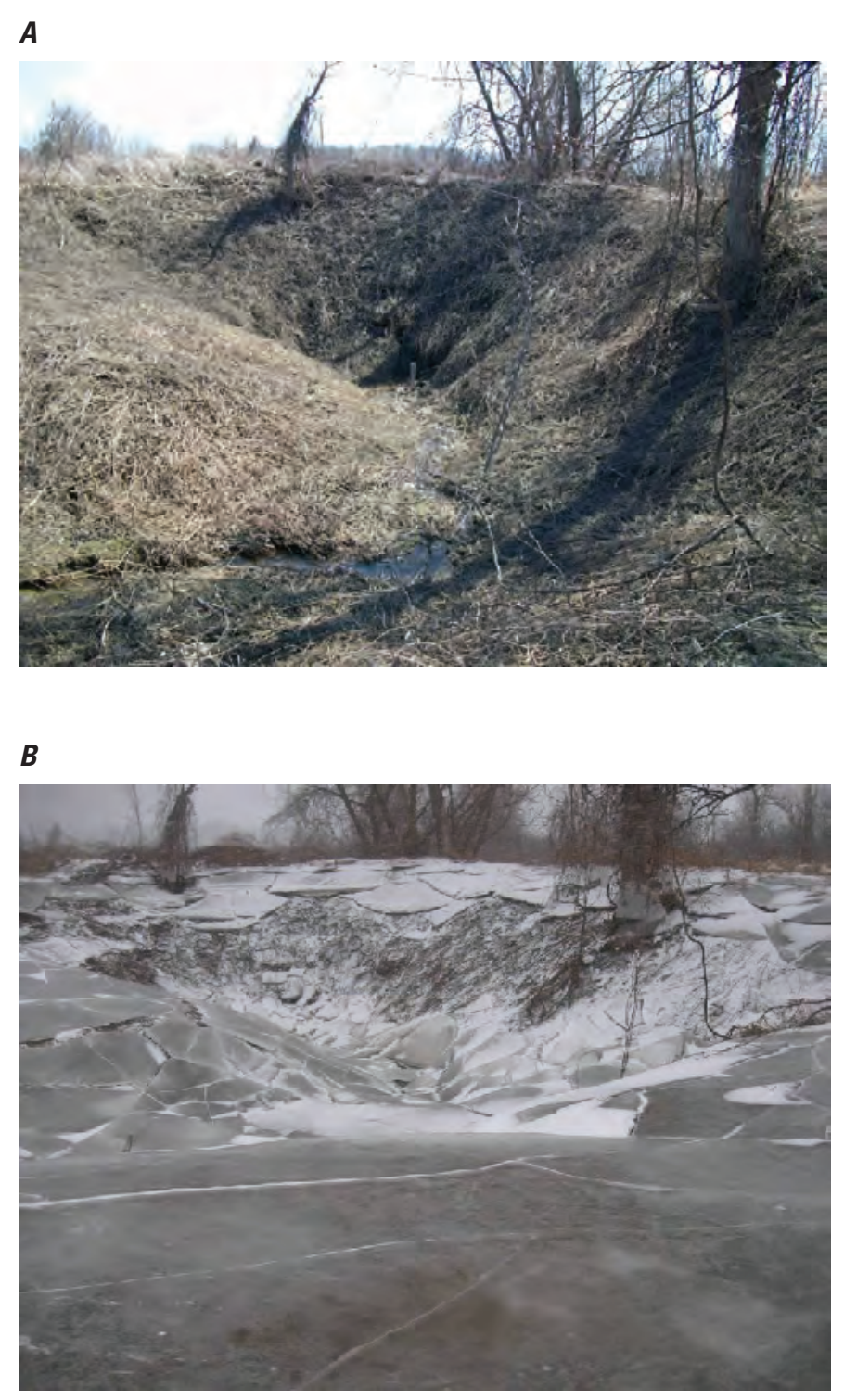

Figure 2. A small sinkhole in Genesee County, New York, $A$, with a small stream disappearing into it (a swallet) and $B$, in early spring. As snowmelt runoff exceeded the swallet capacity, the area flooded, and an ice sheet formed. When runoff ceased and all water drained into the swallet, the unsupported ice cover collapsed into it. Photographs courtesy of Paul Richards, State University of New York at Brockport. 


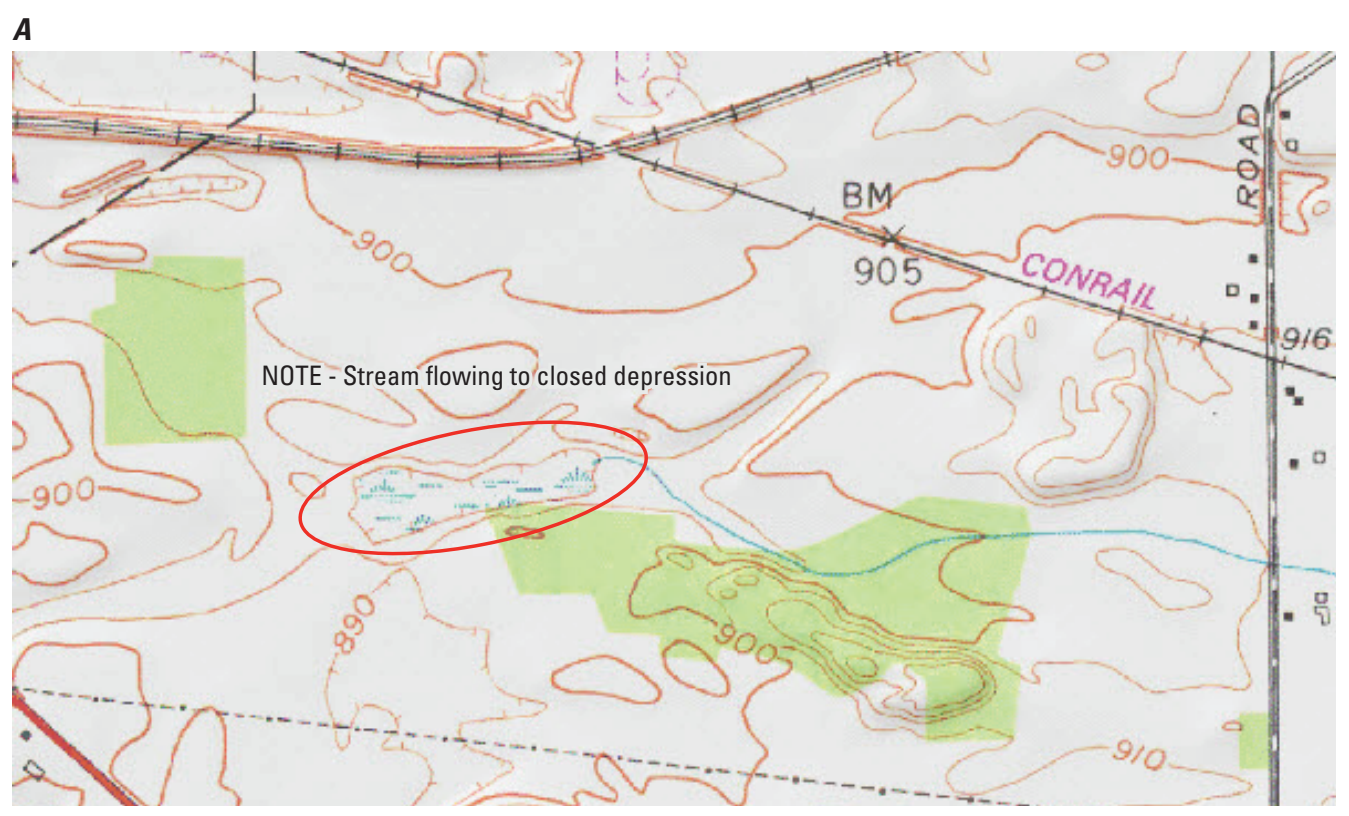

B

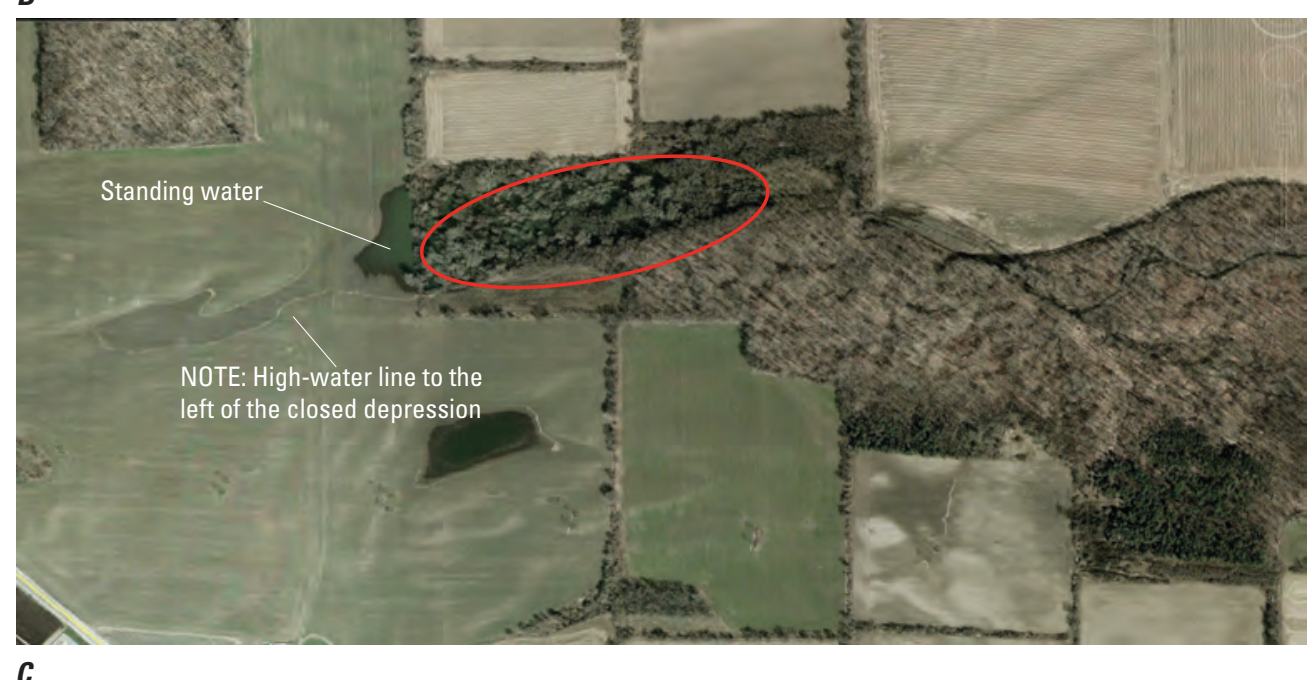

C

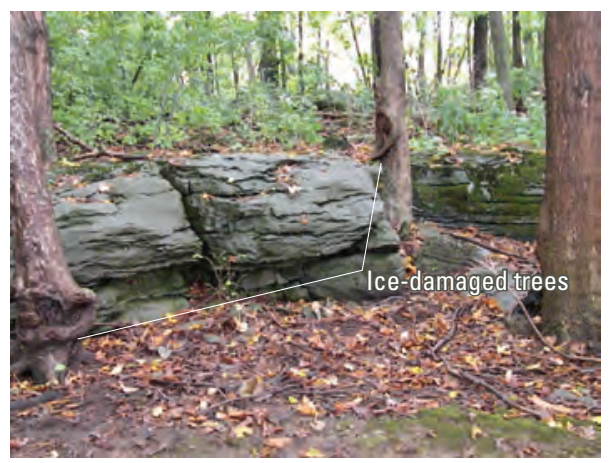

Figure 3. A closed depression near Batavia, Genesee County, New York, from $A$, a part of a 1:24,000-scale topographic map and $B$, a Google Earth image showing a closed depression (red ellipse) and $C$, the interior of the closed depression where surface water infiltrates into the Onondaga Limestone. The high-water line is shown to the left of the wooded area and standing water adjacent to the woods. Tree 'scars' $(C)$ appear where ice formed when the depression was filled with water and the ice damaged the bark layer of several trees. 


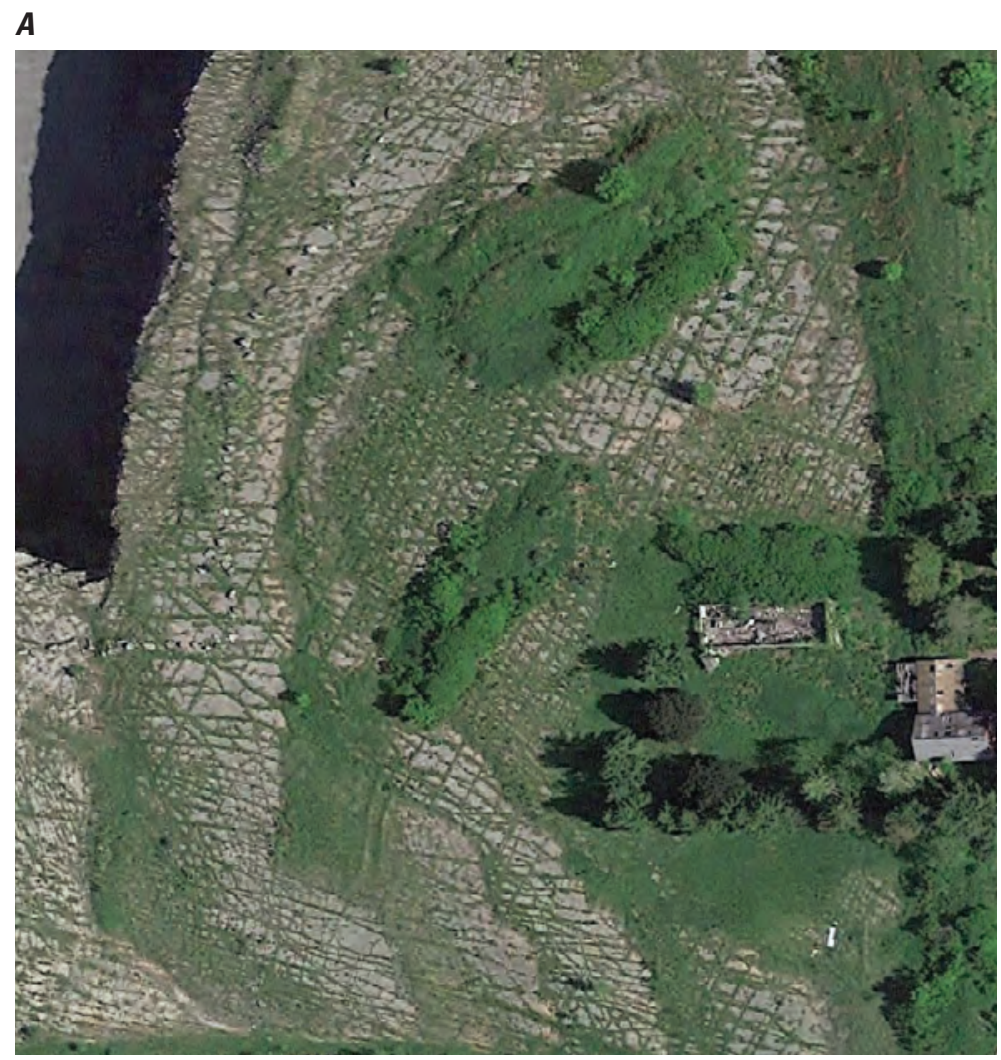

$B$

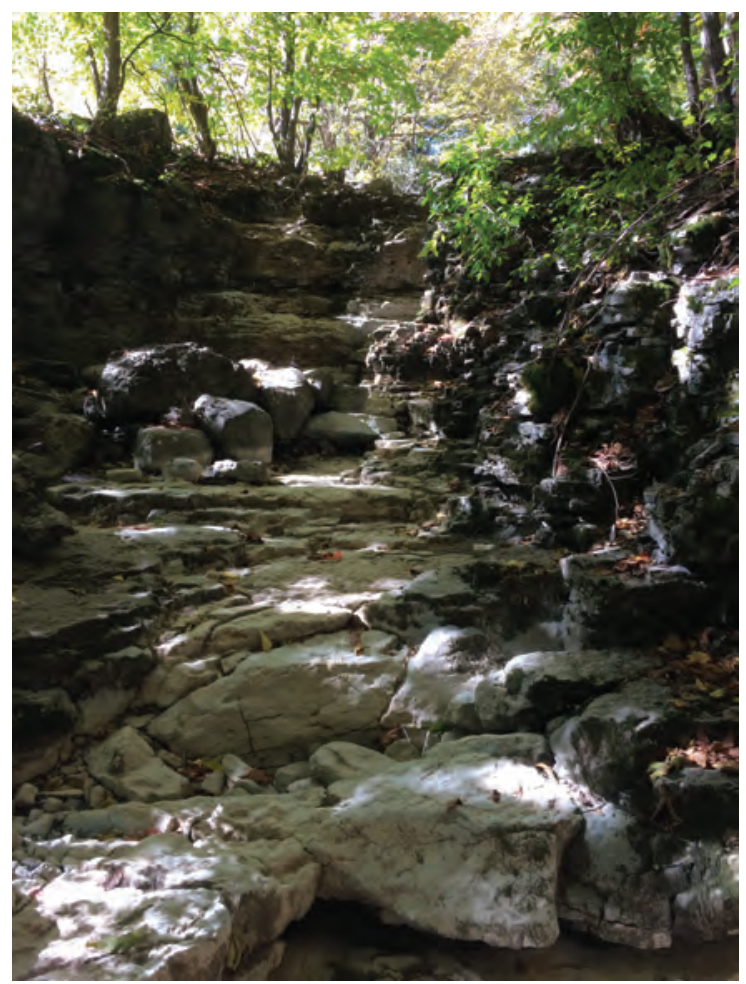

C

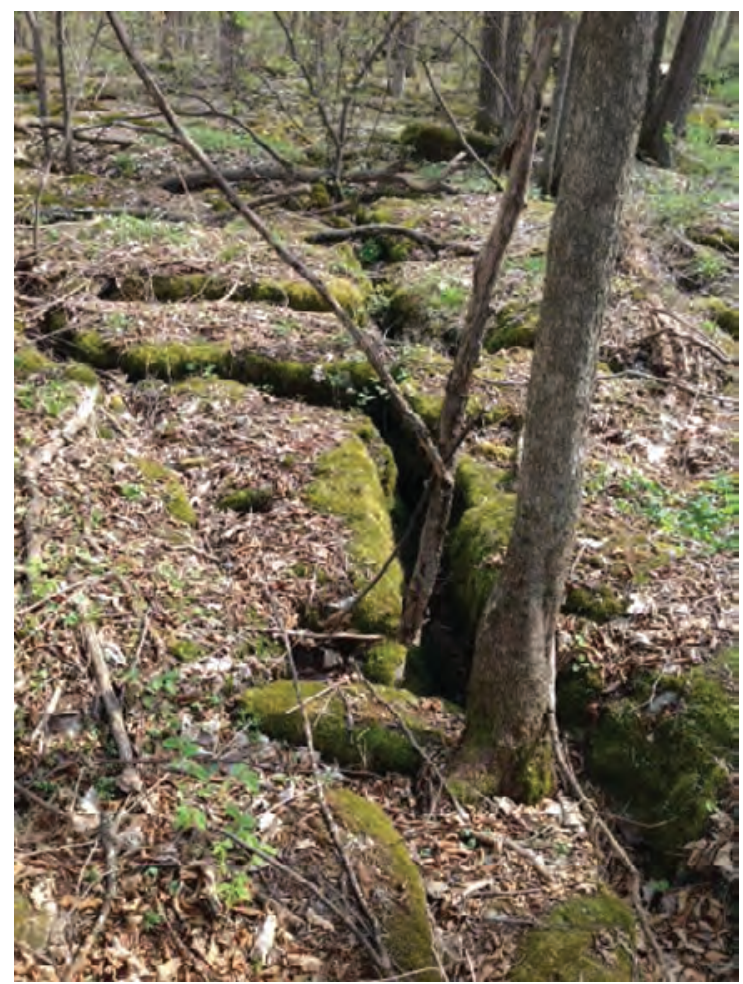

Figure 4. Karst bedrock features in Madison County, New York. $A$, Google Earth image of the fractured bedrock surface at a limestone quarry north of Perryville, New York; quarry floor is in the shadow left of the fractured bedrock surface. $B$, Dry streambed in carbonate bedrock; the streamflow disappears into the bedrock upstream from this location. $C$, Karren pavement with trees growing between fractured and solutioned carbonate bedrock. 
$\boldsymbol{A}$

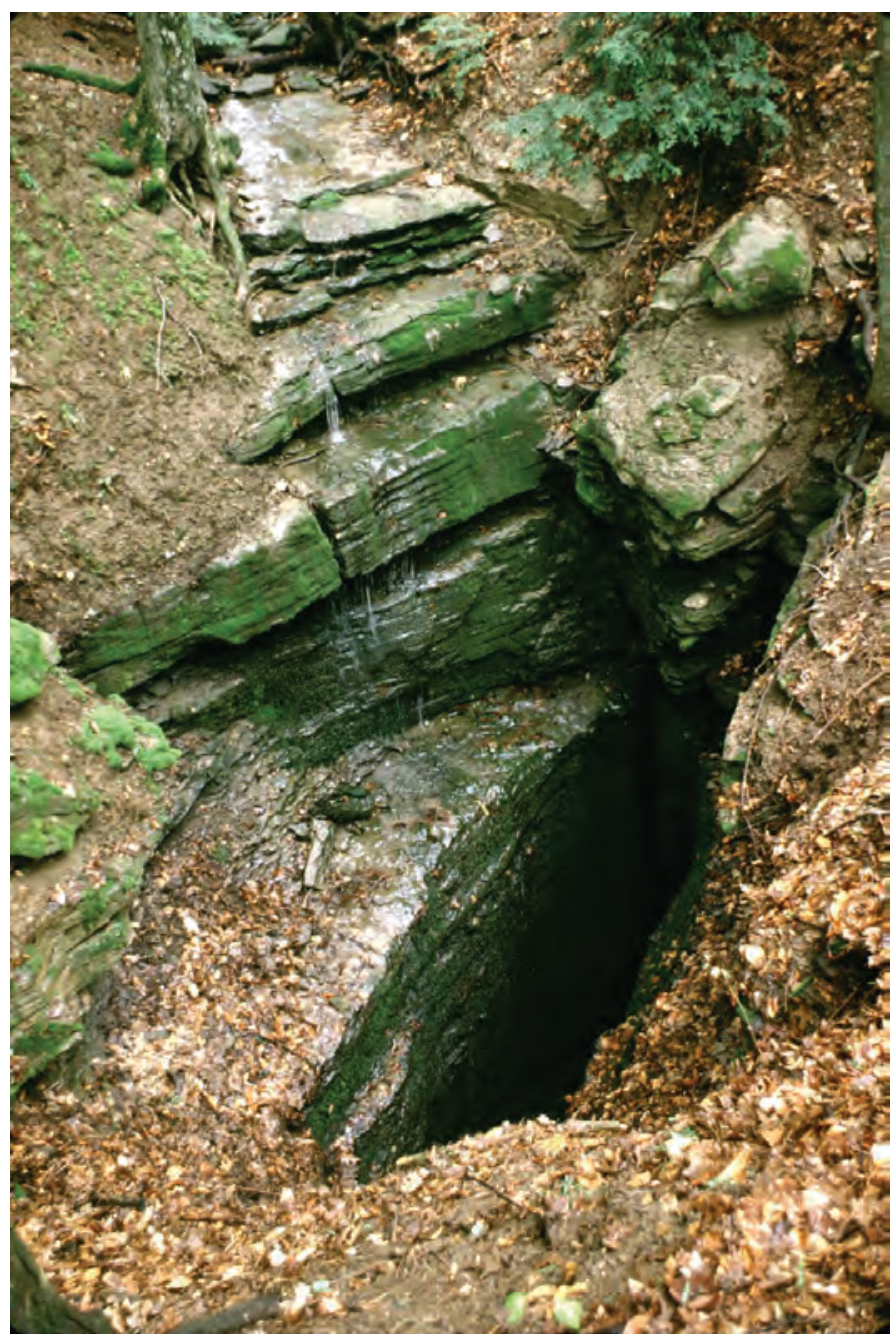

B

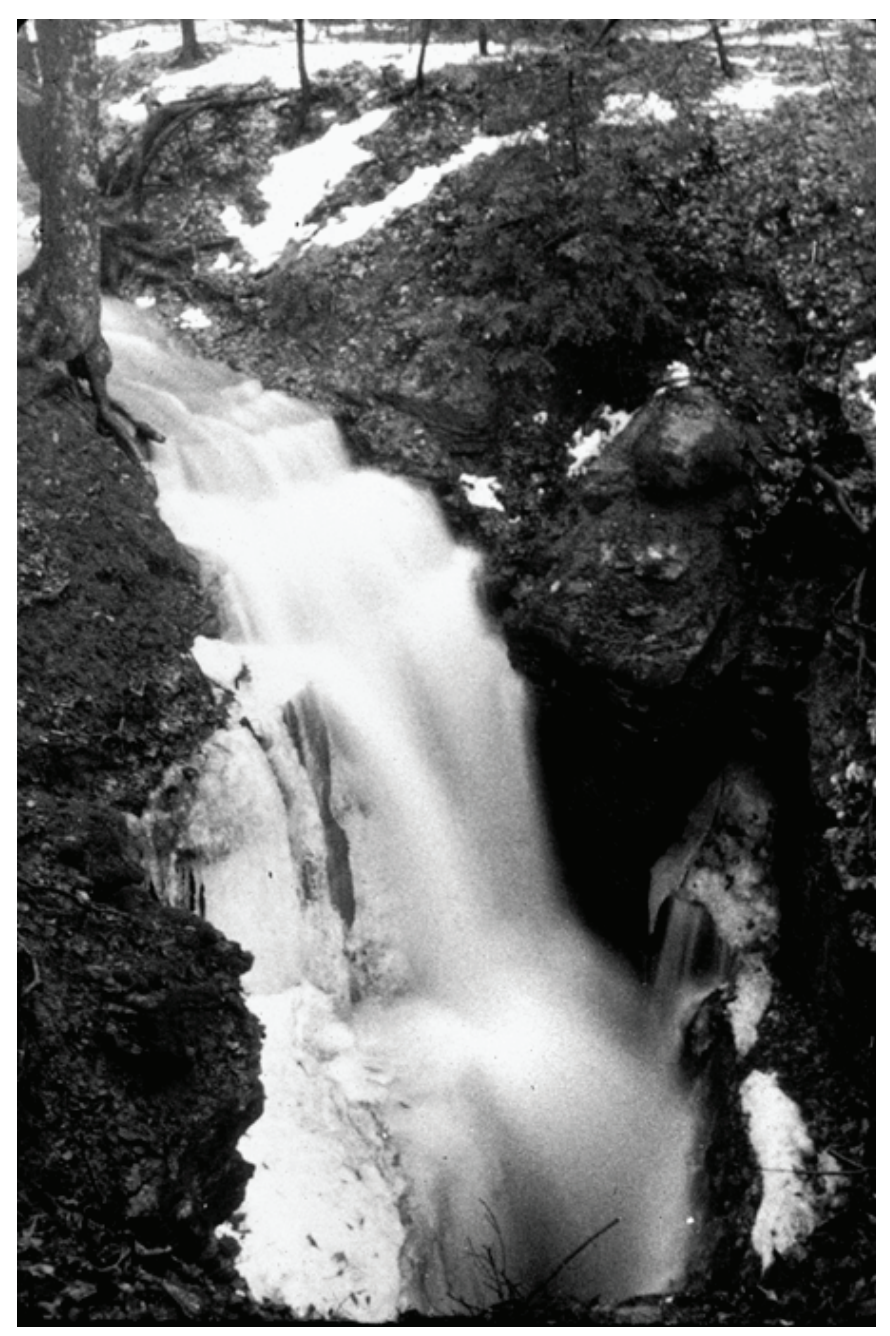

Figure 5. Swallet entrance to McFails Cave in Schoharie County, New York, during $A$, the dry season and $B$, a 50-year flood discharge in January 1996; photographs courtesy of Art Palmer, professor emeritus, State University of New York at Oneonta.

\section{Contamination in Karst}

The karst landscape creates a situation where surface water and any contamination source can rapidly move from the land surface to an underlying aquifer. These contaminants, after entering the aquifer, can move rapidly with groundwater from areas of focused recharge to points of discharge and to any other intermediary location where groundwater is withdrawn, such as a water-supply well.

Karst aquifers are susceptible to contamination beneath urban areas from varied contaminant sources, including septic-tank effluent, runoff containing metals, oil and grease, solid and liquid wastes, and accidental or intentional dumping of chemical wastes by industrial facilities and homeowners (Veni and others, 2001). Karst aquifers in New York have been contaminated by unintended or improper chemical disposal or spills of contaminants such as petroleum products or trichloroethene (TCE) and its breakdown residuals. These contaminants, dependent on their nature, can readily move into karst aquifers to cause short- or long-term water-quality issues in regional aquifer systems (fig. 6). The age and degree of dissolution in karst bedrock can also lead to land-surface subsidence and infrastructure issues (leaking pipelines and storage tanks or damaged septic systems resulting from subsidence) in rural and urban settings which, in turn, might also affect local and regional water quality.

In rural and agricultural areas, karst aquifers are also subject to environmental degradation from a variety of sources, including natural and chemical fertilizers, pesticides, and herbicides, along with their breakdown products (Veni and others, 2001). In New York, groundwater contamination from liquid manure applications and resulting water-quality issues, such as fecal coliform bacteria (Escherichia coli [E. coli]) and nitrate, were increasing in the early 2000s, and contamination incidents were reported to the NYSDEC (Reddy and 


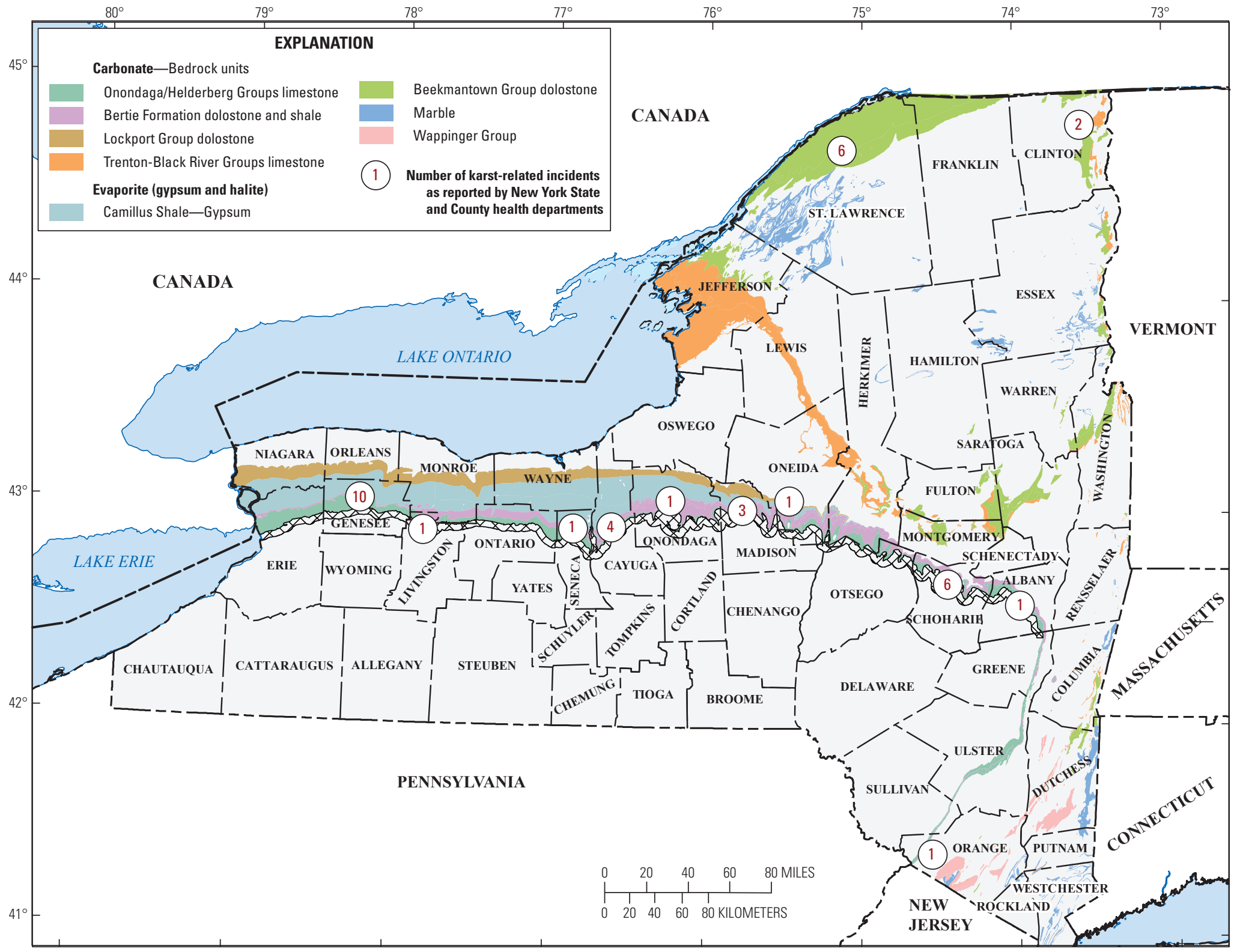

Figure 6. Contamination issues in karst areas in New York, by county, as reported by the New York State Department of Health and county health departments between 2000 and 2016 . 
Kappel, 2010). Nitrate from fertilizer is highly soluble in water and thus can move readily through the soil and enter the groundwater system. E. coli bacteria are not water soluble, but because of their small size, they can move through larger soil pores and into bedrock fractures, especially solutionwidened fractures in the karstic rock. The high water content and organic nature of liquid manure may enhance movement of some contaminants under certain meteorological and soil conditions. As these rural contamination issues were being reported, the use of bacterial source tracking - using DNA "fingerprints" to determine the source(s) of E. coli pollutionidentified or ruled out certain bacterial sources, allowing watershed management decisions that are better informed.

\section{New York Bedrock as Affected by Karst and Glacial Processes in New York State}

Karstification in New York State is highly variable because of the type of bedrock present; how the bedrock has been affected by tectonic, glacial, and other geological forces; the amount of water that moves through the karst aquifer (focused recharge); the topographic position of the rock; and how long the dissolution process has been active. Most of the bedrock in New York has little in the way of primary permeability and porosity - that is, water cannot easily move through or be stored in the bedrock matrix. Secondary permeability in the form of bedrock joints and other fractures was created by continental tectonic forces and stress relief including the loading and unloading of glacial ice. Weathering and dissolution of bedrock fractures in carbonate and evaporite bedrock increase the amount of water moving through the fracture system, which further enhances water movement, widens and lengthens openings, and increases permeability (sometimes termed tertiary permeability) and storage, (Ford and Williams, 2007; Kresic, 2007). In the short term, these processes can create simple, localized recharge to and discharge from a fracture or set of connected fractures over several hundreds or thousands of feet. In the long-term, these processes can create complex regional conduit and cave systems that can extend in three dimensions throughout a carbonate bedrock sequence over many square miles. How these systems develop can mean the difference between diffuse flow systems that may be seasonally unaffected by individual precipitation events and systems that may, under focused-recharge conditions, rapidly transmit surface water to groundwater and then rapidly allow groundwater to reappear as surface water at a downgradient discharge location.

Although the extent of karst development is important for understanding the surface water-groundwater interaction in a karst terrain, "the number of karst features has little to do with the problems of groundwater flow and contamination in karst. In fact, sparse karst can give a false security. Some of the worst cases of groundwater contamination are in carbonates with only minor karst features" (Art Palmer, professor emeritus, State University of New York at Oneonta, written commun., 2016).

\section{Karst Hydrology: New York Examples}

Rapid changes in groundwater levels in karst aquifers highlight the hydraulic effect of focused recharge. For example, in Livingston County in western New York, there are two groundwater wells (LV county designation) about 3 miles (mi) distant from each other, and water-level changes are monitored as part of the statewide groundwater level cooperative monitoring program between the NYSDEC and the USGS. These two wells (U.S. Geological Survey, 2015) are near Caledonia (fig. 7); one well monitors the groundwater level in a surficial sand and gravel aquifer (well LV 330; USGS site number 425833077503901) and the other monitors the groundwater level in the underlying Onondaga Limestone, a karstic bedrock aquifer (well LV 333; USGS site number 425844077532901).

The water levels in the two wells both react to individual precipitation events, but the magnitude of reaction is quite different. The water level in well LV 330 changed only about 0.3 $\mathrm{ft}$ between summer and fall 2016, following a summer-long drought and subsequent average amounts of autumn precipitation and recharge. On the other hand, the water-level change in well LV 333 was about $12 \mathrm{ft}$ during the same period (fig. 7). Following one precipitation event in which about 2 inches (in.) of precipitation fell on October 21, 2016, the water level in well LV 330 rose by about $0.20 \mathrm{ft}$ during the following few days, whereas the water level in well LV 333 rose by more than $11 \mathrm{ft}$ and then declined rapidly by more than $3 \mathrm{ft}$ the following day. Knowing how and where water moves into and out of a karst aquifer system is important, as was demonstrated in this example case: the Onondaga Limestone, like many karst aquifers, has limited storage capacity but can rapidly transmit water through bedrock solution-enhanced fractures.

In this same area, the effects of water moving through karst can be seen by comparing two aerial images of a closed depression at a nearby golf course just east of LeRoy and west of Caledonia (fig. 8). In figure $8 A$, there is a slight trace of a dry streambed and several small sinkholes in the upper photograph, but in figure $8 B$, the same closed depression is filled with water with a high-water outlet at the upper (northern) end of the pond. Water filled this depression from both surface runoff from the upgradient shale bedrock watershed (which is termed allogenic recharge) as well as groundwater flowing in bedrock fractures that filled then overflowed the fractures to create the standing water body. Reportedly from groundskeepers at the golf course, in most cases, this closed depression fills and drains within a few days. 

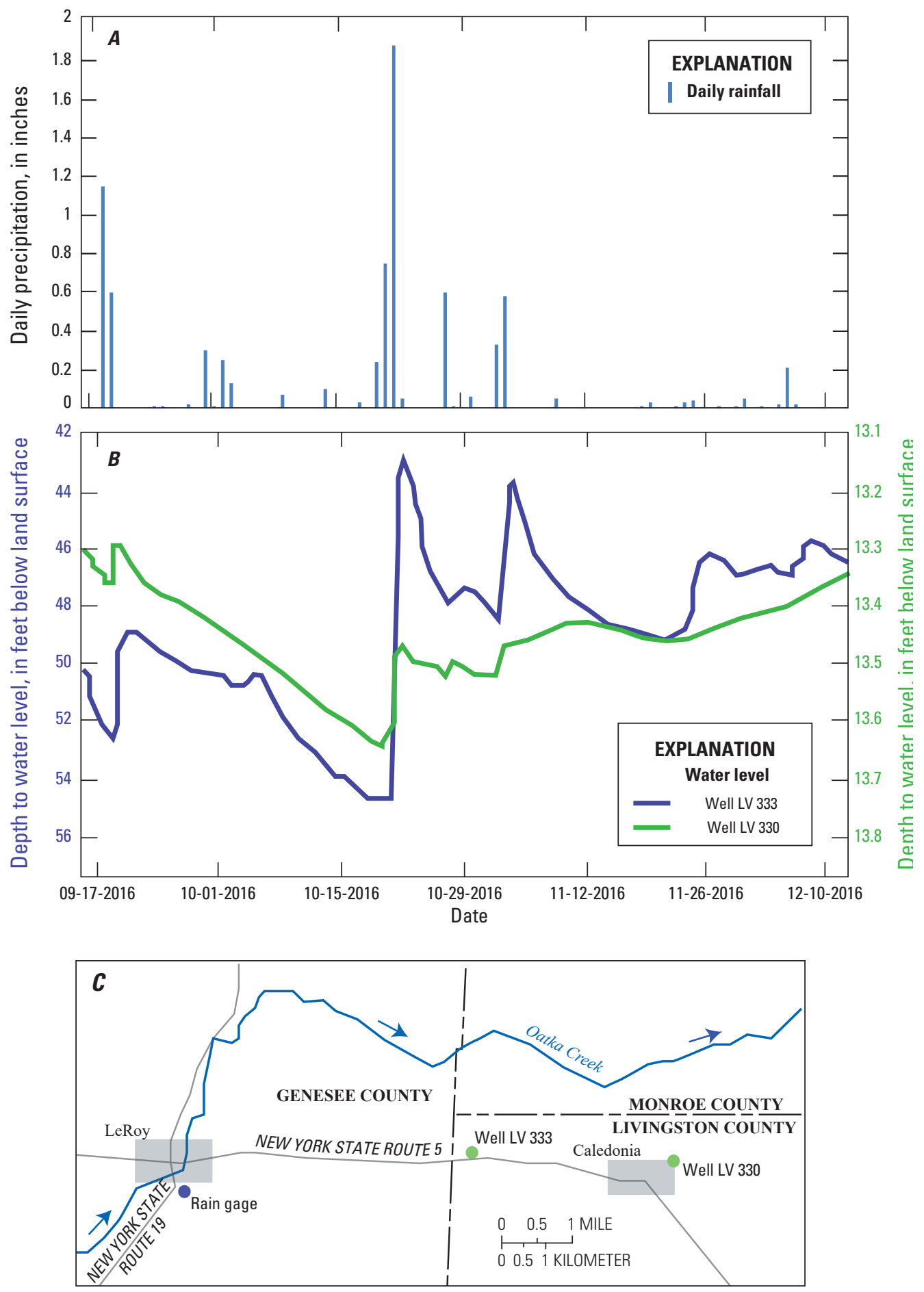

\section{EXPLANATION}

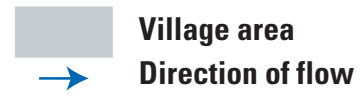

Figure 7. Comparison of two well hydrographs and local rainfall between mid-September and mid-December 2016 in western New York. A, Precipitation in LeRoy; B, water-level fluctuations at well LV 330 in an unconsolidated sand and gravel aquifer (green line) and well LV 333 in the Onondaga Limestone bedrock aquifer (blue line); C, location map for wells LV 330 and LV 333 and LeRoy. Note difference in water-level elevation scales for the two wells. 
A similar karst situation occurs further east, near Marcellus in Onondaga County, at the locally so-called "Disappearing Lake." The closed depression is dry in September (fig. $9 A$ ) but filled with water in June (fig. $9 B$ ) with allogenic recharge from the surrounding steep shale hillsides and the interaction with the underlying karst aquifer (Proett, 1978; van der Hoorne, 2010). There are several small exposures of bedrock on the floor of the depression that can only receive or discharge a certain amount of water to or from the underlying carbonate aquifer. The lake feature may take months to drain but, dependent on local precipitation patterns and water table elevations, this flow can rapidly exceed the ability of the bedrock fractures to accept surface water to the groundwater system or discharge groundwater to the land surface

Near the City of Watertown in Jefferson County in northern New York, a holding pond for surface-water runoff was built over the Black River Limestone (fig. 10). The construction drawings clearly show the pond being constructed between several closed depressions, avoiding what could have been subsidence caused by minor sinkhole development or soil being removed by the fluctuating groundwater levels in the limestone bedrock below the clay. The pond functioned as designed for a number of years but then catastrophically failed, draining part of the volume of the pond. A dike was built to isolate the leak and, upon clearing the clay soil from the floor of the pond, a fracture in the limestone bedrock (fig. 10A) and a small solution-enlarged hole along the bedrock fracture were present where the water had drained into the limestone bedrock (fig. 10B). The hole was sealed, the clay replaced and consolidated, and the pond now functions as designed. Reviewing the location of the closed depressions, the orientation of bedrock fractures in the nearby channel of the Black River (fig. 10C), and the joint in the partly drained pond reveal that the fracture orientation extends through two of the closed depressions on either side of the holding pond.

Although the exact cause of the leak is still undetermined, the continuous saturation of the clay over the bedrock feature may have weakened the clay, while the fluctuating water table may have removed the clay from below, making the surface-water-to-groundwater connection. Additionally, several months before the failure, an earthquake occurred to the east in the Adirondack Mountain region. This earthquake may have affected the bedrock fracture and the overlying clay, causing the leak to slowly increase to the point that the clay seal failed and the pond partly drained.

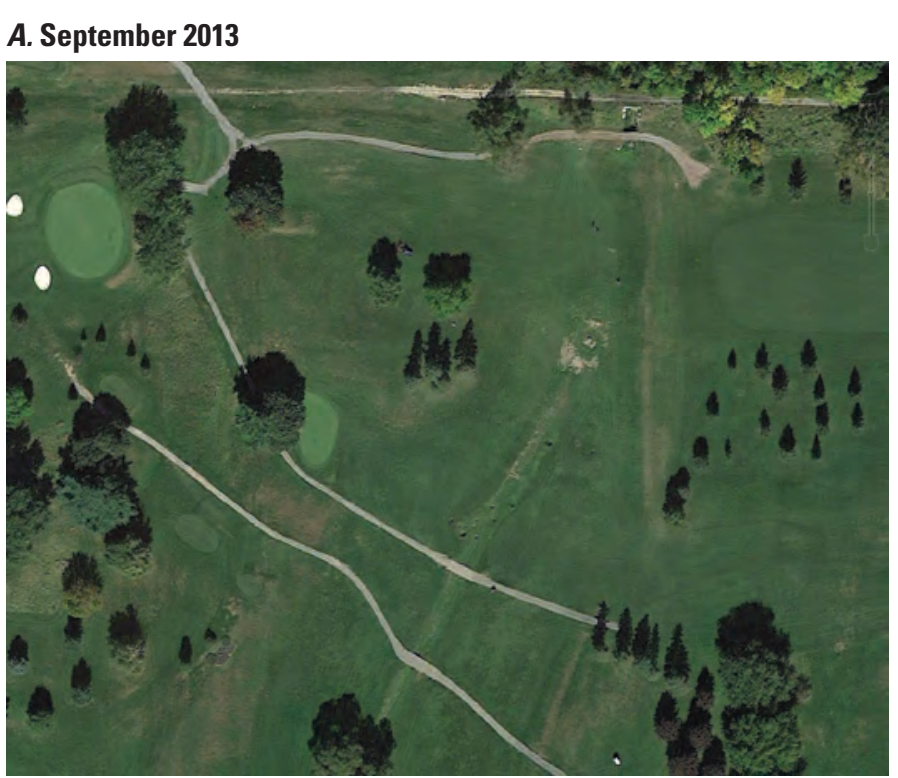

\section{B. March 2010}

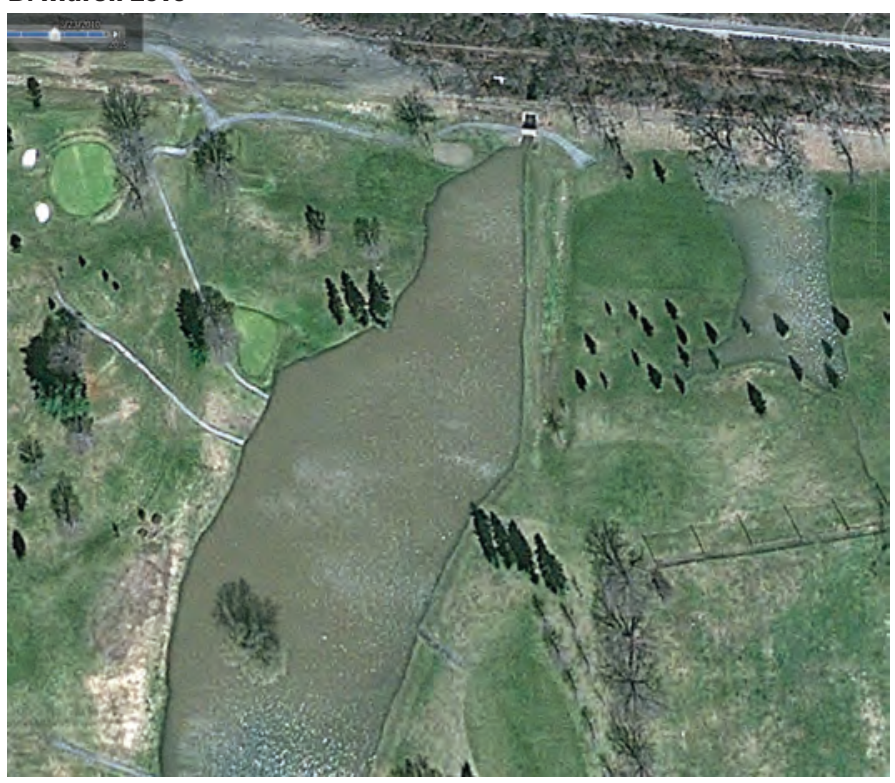

Figure 8. A closed depression (sinkhole-swallet) in Onondaga Limestone at the LeRoy Country Club in LeRoy, Genesee County, New York, in A, March 2010 and B, September 2013. Surface water contributed from a shale bedrock watershed to the south of this view. In March 2010, the depression was filled with surface-water runoff and had a karst water table above land surface, whereas in September 2013, the karst water table was below land surface. 


\section{A. September 2009}

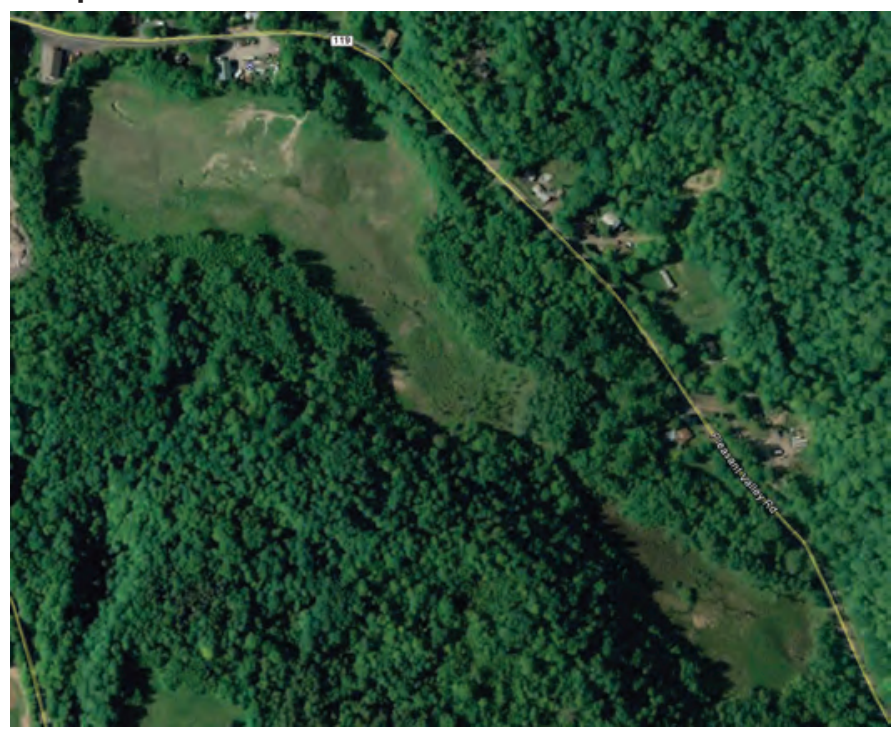

\section{B. June 2011}

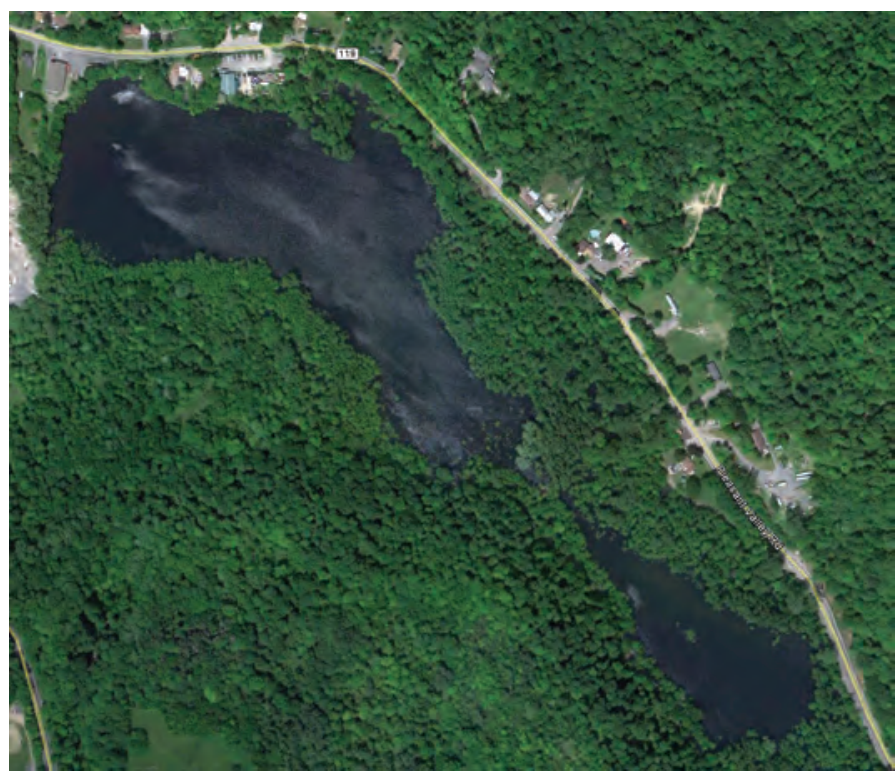

Figure 9. Disappearing Lake near Marcellus, Onondaga County, New York. $A$, Aerial image from September 2009, with no standing water in the closed depression; B, Aerial image from June 2011 following a wet spring season, where runoff from the surrounding shale hillsides has filled the closed depression and water is slowly draining into the underlying Onondaga Limestone.

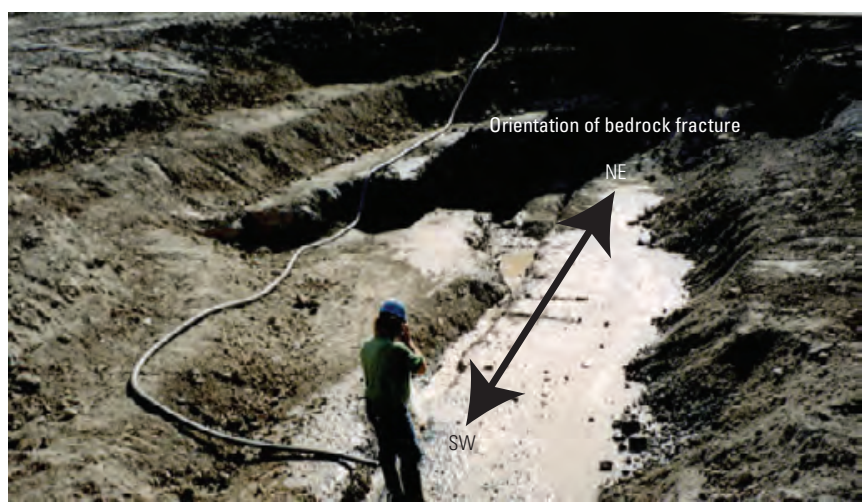

B

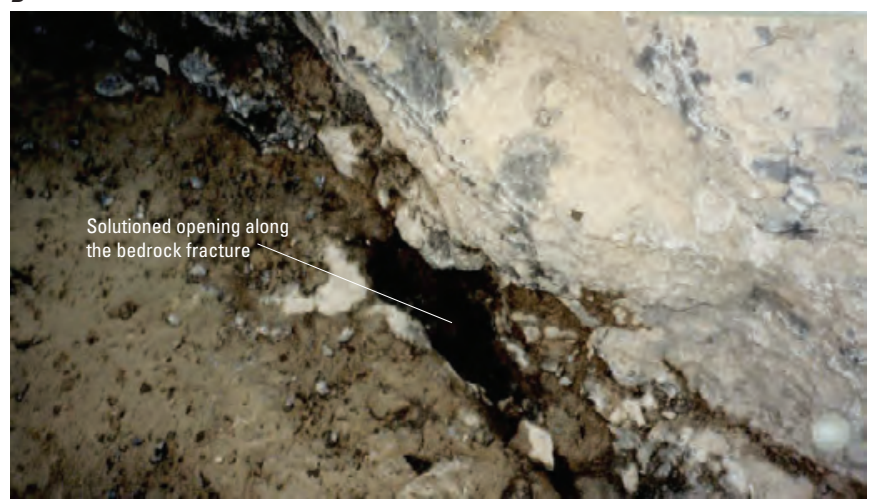

C

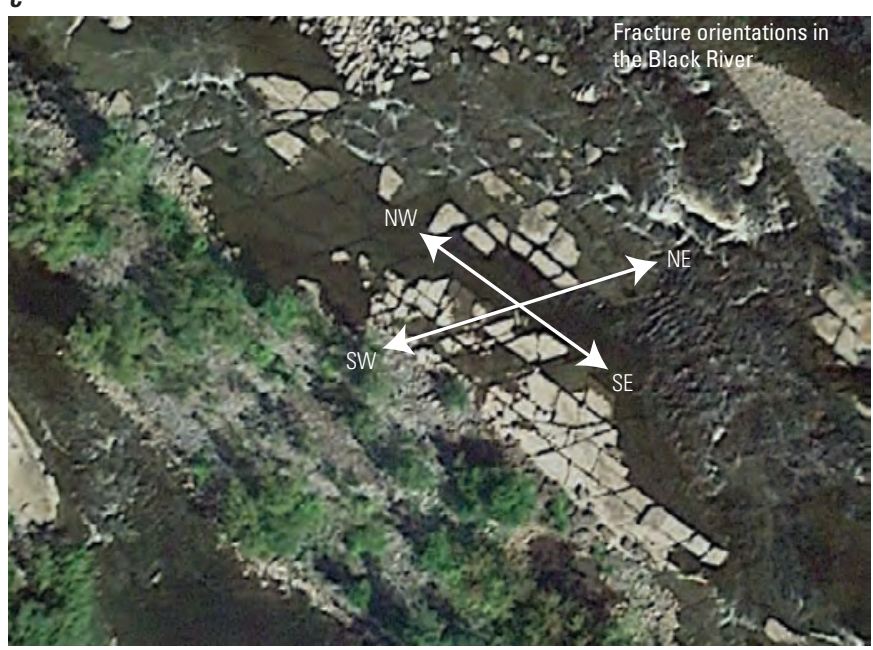

Figure 10. Draining of a surface-water holding pond in Watertown, New York. $A$, Bedrock fracture found below approximately 6 feet of glacial clayey soil in which the holding pond was located; $B$, solutional opening along this fracture where surface water drained to groundwater; $C$, orientations of primary bedrock fractures in the Black River, southwest of the holding pond and east of the New York State Route 12 bridge in Watertown. 


\section{Karst in Bedrock of New York State}

In New York State, karst is present in a number of bedrock lithologies (limestone, marble, dolostone, and shale with evaporite deposits; table 1.1) and is also dependent on the structure of and within the rock (strike and dip of the rock and the presence of joints, fractures, faults, and bedding planes within the rock mass). Karst develops in either gently dipping west-to-east oriented bands in western and central New York or in steeply dipping beds or isolated exposures in southeastern New York. Weary (2008) characterizes New York's carbonate karst into two major groups, each with a subgroup based on glacial-cover thickness.

The first group of bedrock consists of gently folded and flat-lying carbonate rocks that have not been strongly deformed. One subclass of this group is thinly covered with glacial material and the other subclass has thick (more than $50-\mathrm{ft}$ ) unconsolidated glacial materials that tend to obscure karst land-surface features. In this group, where the carbonaterocks are thick and extensive, cave systems may be long and complex. Where the carbonates are thin and interbedded with noncarbonates, caves are small and short (Weary, 2008). Palmer (1991) indicates that the geometry of caves that follow stratigraphic and bedding planes form meandering branchwork (stream-like) caves and passages.

The second group of karst bedrock is composed of folded and faulted carbonate rocks flanking structural deformation zones that may be intensely folded, jointed, and faulted. Caves can be small and simple or long and complex (Weary, 2008). Palmer (1991) indicates that cave patterns in this group show structural control and form networked (angular grid- or roadlike) cave patterns as well as vertical connections to the land surface. Here, too, where the glacial deposits are thick (more than $50 \mathrm{ft}$ ), the karst features typically are not apparent at land surface.

Cooper and Mylroie (2015) described the geologic age and location of karst bedrock in New York (fig. 1; table 1) as

- Precambrian Grenville Complex marble in the Adirondack Mountain region;

- Precambrian, Cambrian, and Ordovician marble in eastern New York (Wappinger and Chazy Groups);

- Cambrian and Ordovician limestone in northern New York lowlands and the Mohawk Valley (Trenton Group, Black River Group, and Beekmantown Group);

- Silurian and Devonian limestone and dolostone in nearly flat-lying beds from western to east-central New York (Onondaga Limestone, Helderberg Group, and Lockport Group), and within gypsum- and halitebearing shale (Salina Group) in western to central New York. Other carbonate beds are present in the Silurian and Devonian sequence and can be karstic locally (such as the Manlius, Coeymans, Rondout, and Tully
Limestones and the Akron-Bertie Dolostone), but they are not highlighted here because they are generally associated with the previously mentioned bedrock units.

- Silurian and Devonian limestone and dolostone in structurally deformed and steeply dipping beds along the western side of the Hudson River Valley in eastern New York (Onondaga Limestone and Helderberg Group).

All bedrock in New York has been affected to various degrees through geologic time by continental movement (plate tectonics) and the associated structural deformation including folding, fracturing, and faulting. In an extreme case in the lower Hudson River Valley, bedrock strata have been deformed from a horizontal to a nearly vertical orientation (fig. 11A). The Adirondack Mountain dome continues to rise to this day, slowly deforming the sedimentary bedrock that surrounds it.

During the past 2.6 million years, bedrock in New York State has been subjected to periods of continental glaciation (Fullerton, 1980) and intervening periods of erosion and deposition by fluvial processes. During and following each glacial period (1) the bedrock surface was reshaped, (2) surface-water and groundwater drainage patterns were modified, locally and regionally, (3) internal drainage through dissolution of carbonate rock or evaporite deposits was enhanced, and (4) internal bedrock flow and storage were increased, developing secondary and tertiary permeability and porosity. Dependent on the age and degree of karst development, surface water and groundwater interaction in karst has been affected by both glacial and interglacial dissolution processes. For example, some caves predate the most recent glacial episode (Wisconsinan) and were partially filled with glacial sediments that were subsequently re-excavated (fig. 12). Continued dissolution of karstic bedrock today further develops karst systems and highlights the need to understand and protect karst-aquifer water resources in New York State.

The carbonate and evaporite bedrock units in New York have undergone various degrees of karst development, from recent dissolution that may only extend several hundred feet within carbonate bedrock to long-term (several tens to hundreds of thousands of years) development of large karstaquifers that evolved into interconnected cave systems that extend over many square miles. In some places, the karst bedrock is overlain by unconsolidated deposits and bedrock that may be in hydraulic contact with the underlying karstic bedrock, termed subjacent karst. Adjacent and topographically higher nonkarst bedrock can also route surface water and groundwater into a nearby karst aquifer (allogenic recharge). These adjacent areas are part of the focused-recharge watershed of karst aquifers, even though they might not be types of bedrock in which karst would normally form in or flow through. Figures 8 and 9 are examples of shale uplands that drain to a karst feature. 
Table 1. Stratigraphic column of New York State bedrock indicating those units in which karst features might be present

[Cells shaded in blue indicate formations prone to carbonate karst development; cells shaded in green indicate formations somewhat prone to carbonate karst development; cells shaded in orange indicate formations somewhat prone to gypsum evaporite karst development; cells shaded in yellow indicate formations somewhat prone to halite or gypsum evaporite karst development; and cells not shaded indicate formations that do not have karst developmen!

\begin{tabular}{|c|c|c|c|c|c|c|c|c|c|c|}
\hline \multirow{2}{*}{ Period } & \multirow{2}{*}{ Epoch } & \multirow{2}{*}{$\begin{array}{l}\text { Group or } \\
\text { formation }\end{array}$} & \multicolumn{6}{|c|}{ Location of group in New York } & \multirow{2}{*}{ Formation or member } & \multirow{2}{*}{ Generalized lithology } \\
\hline & & & West & Central & East & Southeast & Champlain & St. Lawrence & & \\
\hline \multirow[t]{24}{*}{ Devonian } & Upper & Conewango & $\mathrm{X}$ & & & & & & Cattaraugus & Shale and sandstone \\
\hline & & Conneaut & $\mathrm{x}$ & & & & & & Ellicott/Chadakoin/Whitesville & Shale \\
\hline & & Canadaway & $\mathrm{x}$ & $\mathrm{x}$ & & & & & Gowanda/Dunkirk/Caneadea/Wellsville & Shale and sandstone \\
\hline & & West Falls-Java & $\mathrm{x}$ & $\mathrm{x}$ & & & & & Hanover/Wiscoy/Angola/Nunda/Rhinestreet & Shale; shale and sandstone \\
\hline & & & & & $\mathrm{x}$ & & & & Slide Mountain & Shale, sandstone, conglomerate \\
\hline & & Sonyea & $\mathrm{x}$ & $\mathrm{x}$ & & & & & Cashaqua/Middlesex/Rock Stream & Shale; shale and sandstone \\
\hline & & & & $\mathrm{x}$ & $\mathrm{x}$ & & & & Glen Aubrey/Lower Walton & Shale and sandstone \\
\hline & & Genesee & $\mathrm{x}$ & $\mathrm{x}$ & & & & & West River/Penn Yan & Shale \\
\hline & & & $\mathrm{x}$ & $\mathrm{x}$ & $\mathrm{x}$ & & & & Geneseo/Ithaca/Oneonta & Shale and sandstone \\
\hline & Middle & Tully Limestone & & $\mathrm{x}$ & & & & & Tully & Limestone \\
\hline & & Hamilton & & & $\mathrm{x}$ & & & & Ashokan/Manorkill & Shale and sandstone \\
\hline & & & $\mathrm{x}$ & $\mathrm{x}$ & $\mathrm{x}$ & & & & Moscow/Portland Point & Shale; limestone \\
\hline & & & & & $\mathrm{x}$ & & & & Cooperstown & Shale and sandstone \\
\hline & & & $\mathrm{x}$ & $\mathrm{x}$ & $\mathrm{x}$ & & & & $\begin{array}{l}\text { Centerfield/Ludlowville/Skaneateles/Panther } \\
\text { Mountain }\end{array}$ & Shale and limestone \\
\hline & & & $\mathrm{x}$ & $\mathrm{x}$ & $\mathrm{x}$ & & & & $\begin{array}{l}\text { Marcellus (Union Springs-Oatka Creek)/ } \\
\text { Mount Marion }\end{array}$ & Shale; shale and sandstone \\
\hline & & $\begin{array}{l}\text { Onondaga } \\
\text { Limestone }\end{array}$ & $\mathrm{x}$ & $\mathrm{x}$ & $\mathrm{x}$ & $\mathrm{x}$ & & & Onondaga & Limestone \\
\hline & Lower & Tristates & $\mathrm{X}$ & & $\mathrm{X}$ & $\mathrm{X}$ & & & Bois Blanc/Schoharie & Limestone; shale \\
\hline & & & & & $\mathrm{x}$ & $\mathrm{x}$ & & & Esopus & Shale \\
\hline & & & & $\mathrm{x}$ & $\mathrm{x}$ & $\mathrm{x}$ & & & Oriskany/Glenerie & Sandstone; limestone \\
\hline & & Helderberg & & & $\mathrm{x}$ & $\mathrm{x}$ & & & Alsen/Port Ewen & Limestone; shale \\
\hline & & & & & $\mathrm{x}$ & $\mathrm{x}$ & & & Becraft & Limestone \\
\hline & & & & & $\mathrm{x}$ & $\mathrm{x}$ & & & Kalkberg/New Scotland & Limestone; shale \\
\hline & & & & $\mathrm{x}$ & $\mathrm{x}$ & & & & Manlius/Coeymans & Limestone \\
\hline & & & & $\mathrm{x}$ & $\mathrm{x}$ & & & & Chrysler/Rondout & Dolostone \\
\hline \multirow[t]{14}{*}{ Silurian } & Upper & Salina & $\mathrm{X}$ & $\mathrm{x}$ & $\mathrm{x}$ & & & & Akron/Cobleskill & Dolostone; limestone \\
\hline & & & $\mathrm{x}$ & $\mathrm{x}$ & $\mathrm{x}$ & & & & Bertie & Dolostone with gypsum \\
\hline & & & $\mathrm{x}$ & $\mathrm{x}$ & & & & & Camillus & Shale, with gypsum \\
\hline & & & $\mathrm{x}$ & $\mathrm{x}$ & $\mathrm{x}$ & & & & Syracuse/Wawarsing/Poxono Island & $\begin{array}{l}\text { Shale, with halite, limestone; } \\
\text { shale }\end{array}$ \\
\hline & & & $\mathrm{x}$ & $\mathrm{x}$ & $\mathrm{x}$ & & & & Vernon/Bloomsburg & $\begin{array}{l}\text { Shale, with halite and gypsum; } \\
\text { shale and sandstone }\end{array}$ \\
\hline & & Lockport & $\mathrm{x}$ & $\mathrm{x}$ & & & & & Guelph/Eramosa/Sconondoa & $\begin{array}{l}\text { Dolostone; limestone and } \\
\text { dolostone }\end{array}$ \\
\hline & & & & & $\mathrm{x}$ & & & & Ilion/Shawangunk & $\begin{array}{l}\text { Shale and dolostone; conglom- } \\
\text { erate and sandstone }\end{array}$ \\
\hline & & & $\mathrm{x}$ & $\mathrm{x}$ & & & & & Goat Island/Gasport/Penfield/Sconondoa & $\begin{array}{l}\text { Dolostone; limestone and } \\
\text { dolostone }\end{array}$ \\
\hline & & & & & & $\mathrm{X}$ & & & Green Pond & Conglomerate \\
\hline & & Clinton & $\mathrm{x}$ & $\mathrm{x}$ & $\mathrm{x}$ & & & & DeCew/Glenmark & Dolostone; shale \\
\hline & & & $\mathrm{x}$ & $\mathrm{x}$ & $\mathrm{x}$ & & & & Burleigh Hill/Rochester/Gates/Herkimer & $\begin{array}{l}\text { Shale; dolomite and shale; } \\
\text { sandstone }\end{array}$ \\
\hline & Lower & & $\mathrm{X}$ & $\mathrm{x}$ & $\mathrm{X}$ & & & & Irondequoit/Thorold/Rockway/Dawes & $\begin{array}{l}\text { Limestone and shale; sand- } \\
\text { stone; dolostone }\end{array}$ \\
\hline & & & & & & $\mathrm{x}$ & & & Green Pond & Conglomerate \\
\hline & & Medina & $\mathrm{x}$ & & & & & & Grimsby/Kodak/Power Glen/Whirlpool & $\begin{array}{l}\text { Sandstone; shale and siltstone; } \\
\text { sandstone }\end{array}$ \\
\hline \multirow[t]{9}{*}{ Ordovician } & Upper & Queenston Shale & $\mathrm{X}$ & $\mathrm{X}$ & & & & & Queenston & Shale \\
\hline & & Lorraine & & $\mathrm{x}$ & $\mathrm{x}$ & & & & Oswego/Pulaski/Frankfort & $\begin{array}{l}\text { Sandstone and shale; sand- } \\
\text { stone and shale; shale and } \\
\text { siltstone; shale }\end{array}$ \\
\hline & Middle & Trenton & & $\mathrm{x}$ & $\mathrm{x}$ & & & & $\begin{array}{l}\text { Hillier/Denley/Sugar River/Kings Falls/ } \\
\text { Selby }\end{array}$ & Limestones \\
\hline & & & & $\mathrm{X}$ & $\mathrm{x}$ & & $\mathrm{X}$ & & Utica/Snake Hill/Stony Point & Shale; shale and siltstone \\
\hline & & & & & & & $\mathrm{x}$ & & Glens Falls/Orwell & Limestones \\
\hline & & Black River & & $\mathrm{x}$ & $\mathrm{x}$ & & & & Watertown/Lowville/Pamelia/Isle la Motte & Limestones \\
\hline & & Chazy & & & & & $\mathrm{x}$ & & Valcour/Crown Point/Day Point & Limestones \\
\hline & Lower & $\begin{array}{l}\text { Beekmantown- } \\
\text { Wappinger }\end{array}$ & & & & & $\mathrm{X}$ & & Tribes Hill/Copake & $\begin{array}{l}\text { Dolostone, limestone, and } \\
\text { siltstone; limestone }\end{array}$ \\
\hline & & & & & & $\mathrm{x}$ & & & $\begin{array}{l}\text { Copake/Rochdale/Halcyon Lake (Hudson } \\
\text { Valley area) }\end{array}$ & $\begin{array}{l}\text { Limestone; limestone and } \\
\text { dolostone; dolostone and } \\
\text { siltstone }\end{array}$ \\
\hline \multirow[t]{6}{*}{ Cambrian } & $\begin{array}{l}\text { Upper- } \\
\text { Middle- }\end{array}$ & $\begin{array}{l}\text { Wappinger- } \\
\text { Stockbridge }\end{array}$ & & & & $\mathrm{X}$ & & & Briarcliff/Pine Plains (Hudson Valley area) & $\begin{array}{l}\text { Dolostone; dolostone, sand- } \\
\text { stone, and shale }\end{array}$ \\
\hline & Lower & $\begin{array}{l}\text { New York City } \\
\text { Group }\end{array}$ & & & & $\mathrm{x}$ & & & Inwood & Marble \\
\hline & $\begin{array}{l}\text { Upper- } \\
\text { Middle }\end{array}$ & Beekmantown & & & $\mathrm{x}$ & & & & Tribes Hill/Little Falls/Hoyt/Galway & $\begin{array}{l}\text { Dolostone; limestone; sand- } \\
\text { stone and dolostone }\end{array}$ \\
\hline & & & & & & & $\mathrm{x}$ & & $\begin{array}{l}\text { Providence Island/Fort Ann/Great Meadows/ } \\
\text { Whitehall/Galway }\end{array}$ & $\begin{array}{l}\text { Limestone and dolostone; lime- } \\
\text { stone, dolostone, siltstone; } \\
\text { dolostone and sandstone }\end{array}$ \\
\hline & $\begin{array}{l}\text { Middle- } \\
\text { Lower }\end{array}$ & & & & & & & $\mathrm{X}$ & Theresa & $\begin{array}{l}\text { Dolostone, sandstone, and } \\
\text { siltstone }\end{array}$ \\
\hline & & & & & & & & $\mathrm{x}$ & Potsdam & Sandstone \\
\hline
\end{tabular}

This table can be downloaded as a full-size PDF version at https://doi.org/10.3133/sir20205030. 
$\boldsymbol{A}$

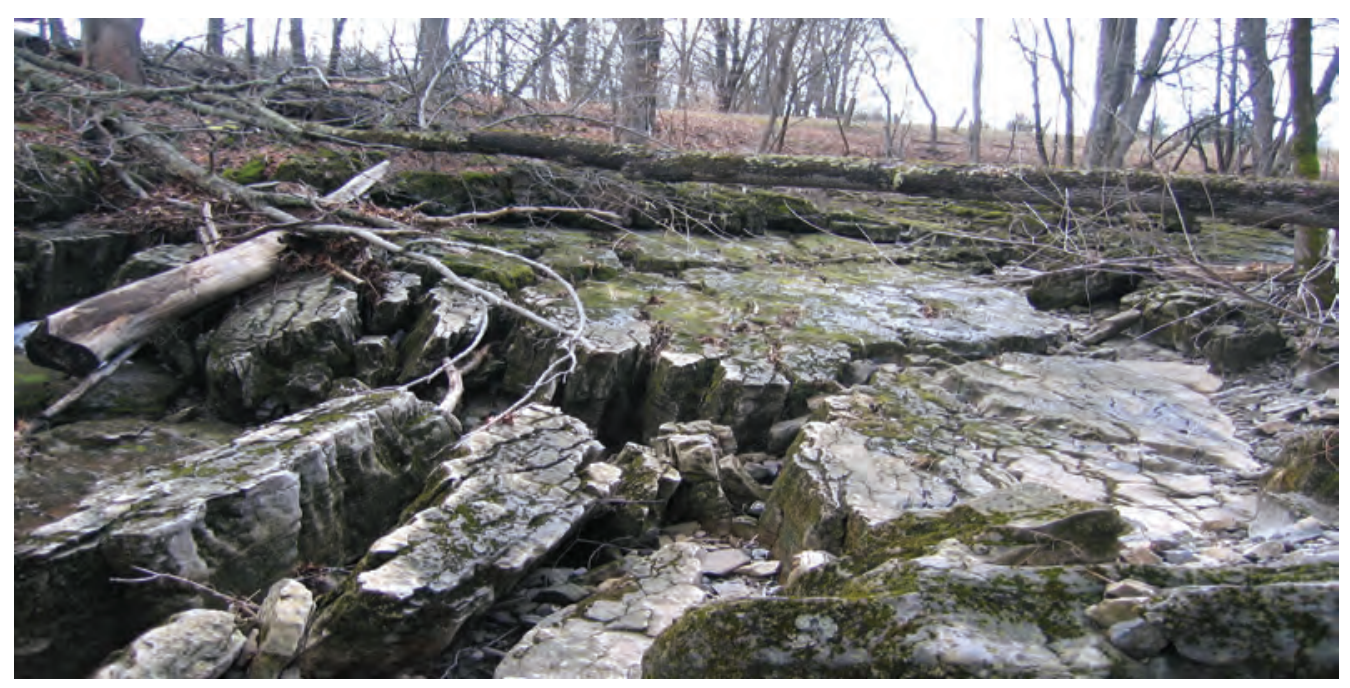

B

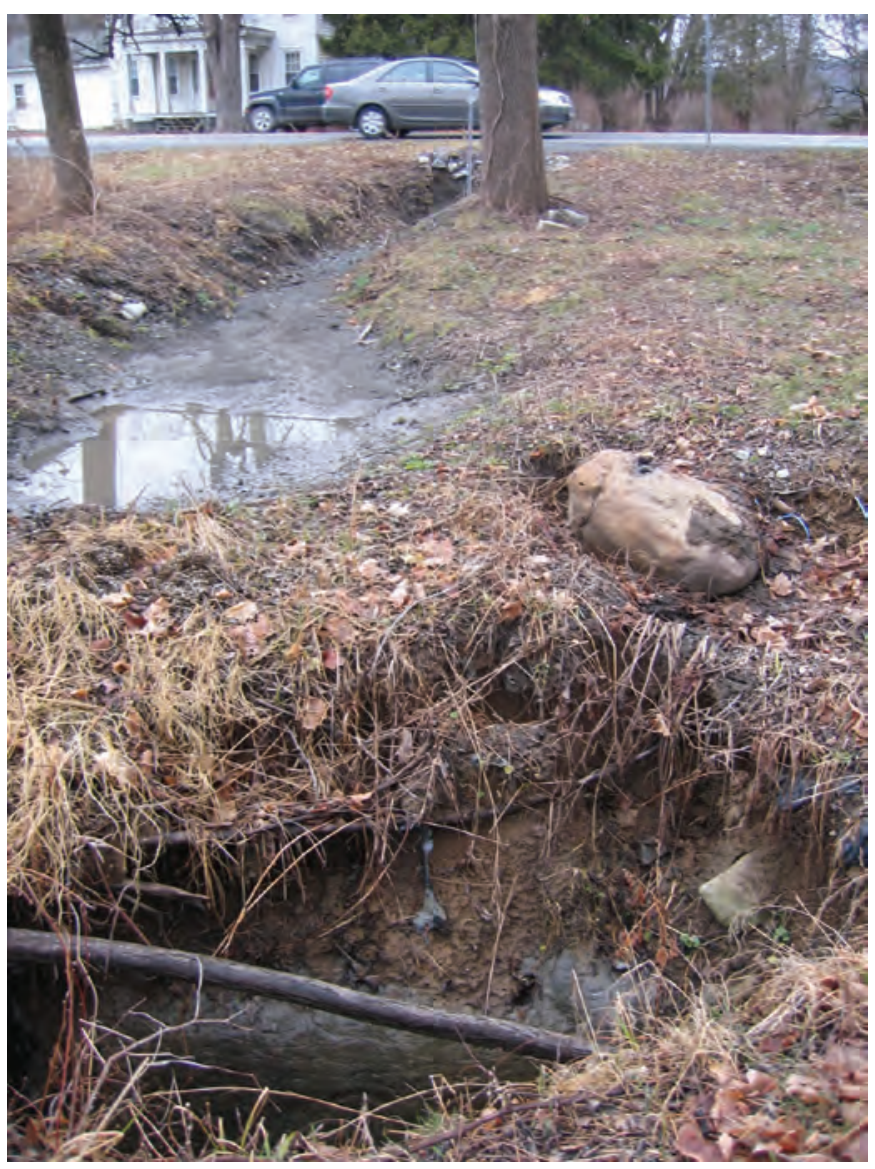

Figure 11. Karst features in the Rondout Valley in Ulster County, New York: $A$, heavily jointed and fractured Onondaga Limestone (note near-vertical bedding orientation of the rock, typical for sedimentary bedrock west of the Hudson River), and $B$, roadside ditch draining into small sinkhole-swallet feature near Stone Ridge, New York. Photographs by Paul Heisig, U.S. Geological Survey. 


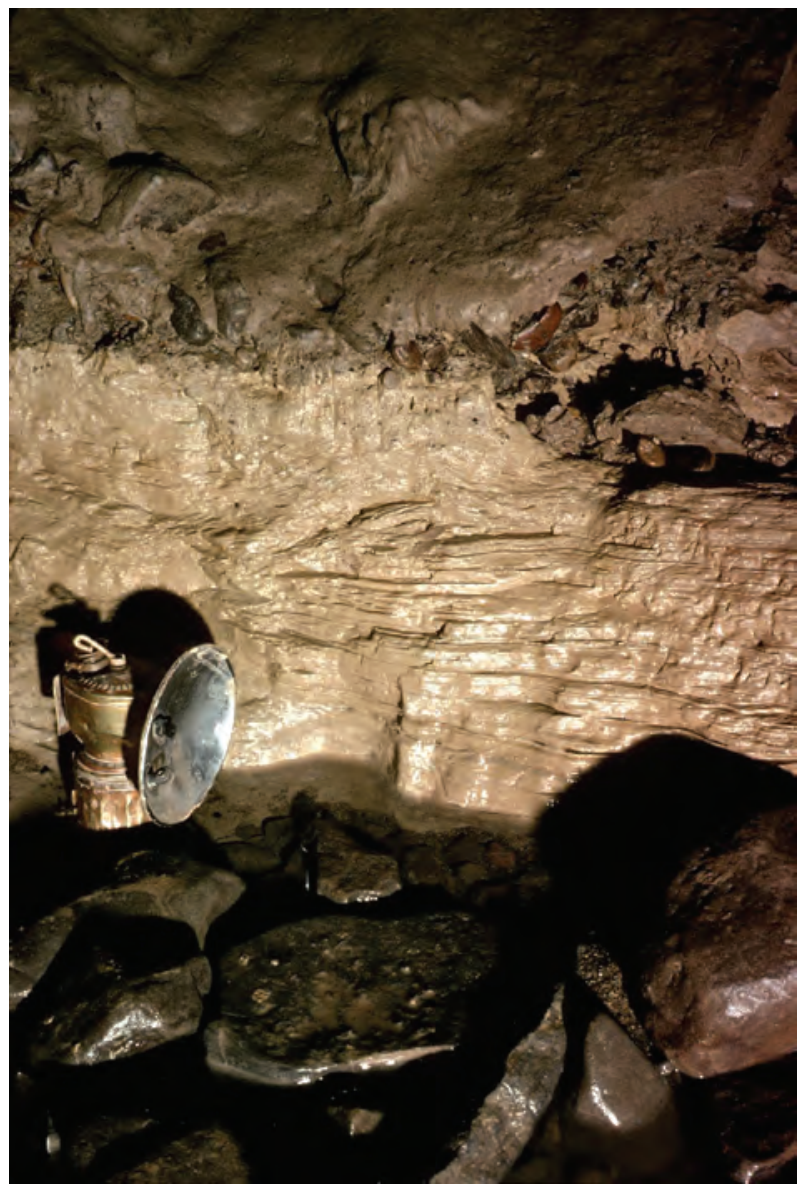

B

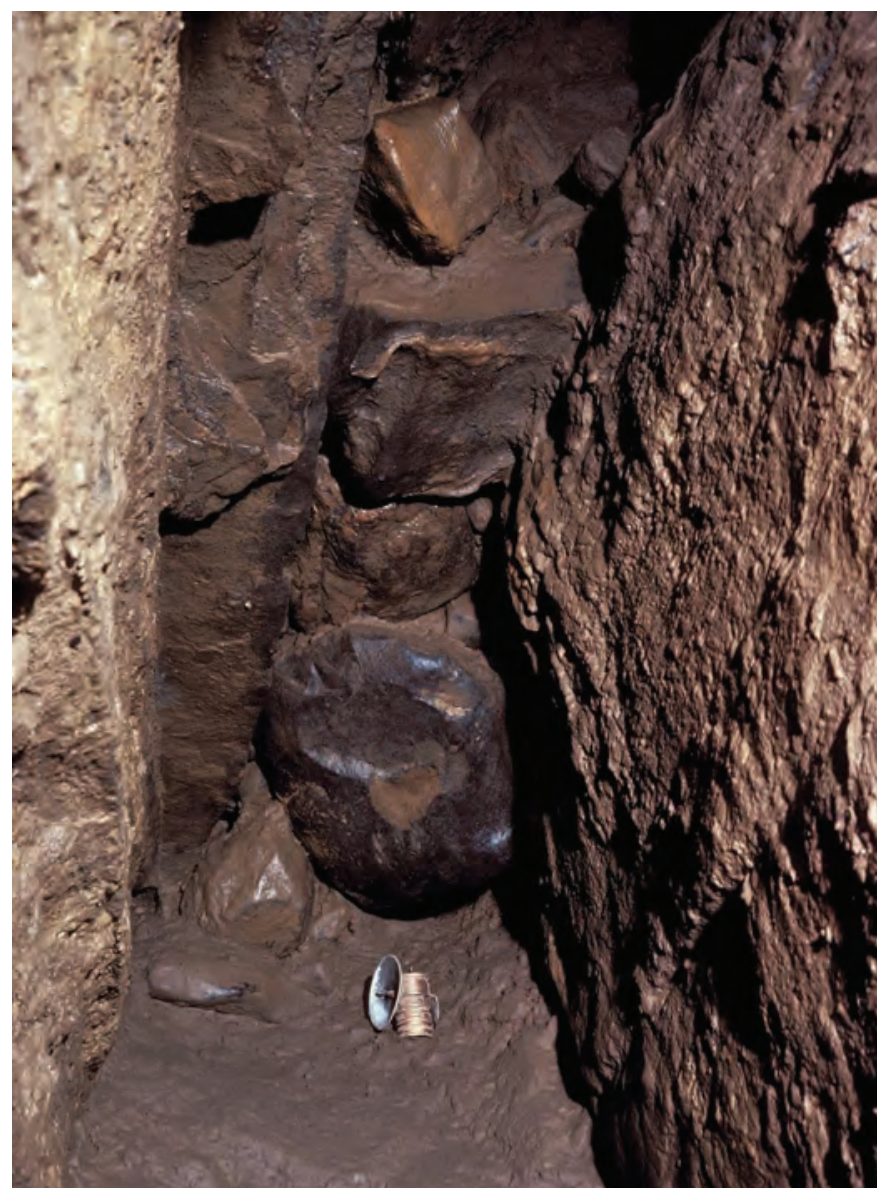

Figure 12. Glacial-related features common in Schoharie Creek Valley caves. $A$, Varved glaciolacustrine clay near the floor of the cave likely deposited during the Wisconsinan glacial period; $B$, glacial boulders trapped in a cave passage. These features indicate the cave was present before and during the Wisconsinan glacial period. Photographs courtesy of Art Palmer, professor emeritus, State University of New York at Oneonta.

\section{Western and Central New York}

Most bedrock in western to east-central New York dips to the south at approximately 30 to 50 feet per mile. Zones of allogenic recharge have been identified in central and western New York, topographically upgradient and south of specific karst units, such as the Onondaga Limestone and Lockport Group. Because of glacial erosion and the dip of the regional bedrock, the Onondaga Limestone is typically at or near land surface at its northern extent, creating a bedrock escarpment (cliff). However, south of the escarpment the Onondaga Limestone is buried by progressively thicker glacial deposits - mostly till and glaciolacustrine fine sand, silt, and clay, but locally sand and gravel (Staubitz and Miller, 1987). The Onondaga Limestone is considered a karst aquifer because of the amount of karst development that has occurred along joints and other fractures and nearly horizontal bedding planes. The Onondaga Limestone has been characterized as a principal aquifer in New York, which is defined as "an aquifer known to be highly productive or whose geology suggests abundant potential water supply, but which is not intensively used currently as a source of water supply by major municipal systems" (New York State Department of Environmental Conservation, 2020).

In a similar fashion, the dolostone of the Lockport Group gently dips to the south and has a northern escarpment in western New York, but the escarpment is buried further to the east. At the Niagara escarpment, the bedrock is at land surface but further to the south, it is buried by thick glaciolacustrine silt and clay, especially in western New York (Kappel and Jennings, 2012). Owing to fine-grained sediment cover and the fact that the dolostone is not as easily solutioned as limestone (because dolostone, which is calcium magnesium carbonate, has different mineral characteristics compared with limestone, which is calcium carbonate), the Lockport Group is less likely to develop karst features. Some karst development in the form of sinkholes and springs has been documented in the Lockport Group but typically along bedding planes near the bedrock 
surface (Yager and Kappel, 1987). Regionally, the Lockport aquifer system is generally confined to these bedding-plane structures and the weathered bedrock surface.

Numerous carbonate rock quarries are present in both the Onondaga Limestone and Lockport Group dolostone in this part of the State. Products derived from these quarries vary from large to small rip-rap rock, construction-base material, and agricultural lime. These quarries generally are dewatered to some extent to allow for the removal of the rock. The amount of water removed is generally greatest in the spring (especially if the quarry shuts down operation in the winter), but the amount of water removed varies between quarry operations. In general, more dewatering takes place from quarries in limestone as compared to those in dolostone due to the greater potential for solutioned-enhanced permeabilities (Kappel and Jennings, 2012).

\section{Northern New York}

In northern New York, the Trenton and Black River Group limestones and Beekmantown Group sandstone and dolostone that surround the Adirondack Mountains (fig. 1) have variable regional bedrock strike and dip. These regional differences in bedrock dip may limit the northern carbonate rocks from having a zone of allogenic recharge similar to the gently dipping, east-west trending carbonate-rock units of central and western New York. The Black River Limestone near Watertown is known for young karst development (shallow solutional fractures, sinkholes, and cave systems), especially where these rocks are adjacent to surface water, such as the Black River (Waller and Ayer, 1975). As an example of this type of karst development, a fluorescein dye trace was completed in the Black River Limestone in December 2016 to determine the connection between some small karst features (swallets) and the Black River. The dye took just over 4 hours to move from the swallets to the Black River, a distance of $1,500 \mathrm{ft}$, and when the dye appeared, its color intensity was not substantially diluted (fig. 13).

The Trenton Limestone, on the other hand, is not known for karst development or for comprising a regionally extensive aquifer system (Waller and Ayer, 1975). The difference between these two units is that the Black River Limestone is generally a massive and pure limestone prone to dissolution at shallow depth and the Trenton Limestone is more argillaceous (shaley), thinner bedded, and less prone to solution.

The Beekmantown Group of northern New York unconformably (former overlying bedrock units not present because of erosion millions of years ago) overlies the Precambrian Shield (Bernstein, 1992); the deep part of the Beekmantown Group is generally a sandstone, but the shallow units are dolostone. The aquifer within the Beekmantown Group is generally present at the weathered bedrock surface and within the relatively shallow fractured bedrock resulting from glacial rebound of the land surface. Fracture density and orientations vary across this system (Cooper and Mylroie, 2015), and karst development is considered young and slowly developing. Bedrock quarries are present in all carbonate units in this region. Dewatering volumes necessary to maintain quarry operations are dependent on the type of bedrock being mined and the location of the quarry in relation to its regional topographic position within the local water table, with greater dewatering volumes being produced when the quarry is below the local water table.

\section{Eastern and Southeastern New York}

In the eastern part of New York, the strata of the Onondaga Limestone and Helderberg Group transition from dipping gently to the south in the Mohawk River Basin to steeply dipping along the western side of the Hudson River Valley. The eastern Mohawk basin has New York's most strongly developed karst, including the oldest known cave systems in the northeastern United States. Lauritzen and Mylroie (2000) have dated stalagmites in some caves to be more than 350,000 years old, indicating cave development through several complete glacial cycles (Cooper and Mylroie, 2015). These caves (figs. 14, 15, and 16) have been explored since the mid-1800s and have been extensively studied since the 1950s (Baker, 1976; Palmer, 1991; Palmer and others, 1991, 2003; Lauritzen and Mylroie 2000; Weremeichik and Mylroie, 2014; Cooper and Mylroie, 2015). It is likely that many more cave systems have yet to be discovered in this area. Numerous large carbonate quarries are present in this part of the State and, depending on their location and elevation within the welldeveloped karst aquifer system, need either substantial or little dewatering to carry on their quarrying operations. At Howe Caverns in Schoharie County, a quarry operation just downgradient from the caverns affected the flow and water level in the caverns until an inadvertent breach of the karst aquifer in the quarry was sealed.

Along the western Hudson River Valley, the tectonic forces that created the valley have caused the sedimentary rocks on the west side to become steeply inclined and fractured. Because of their steep orientation, carbonate rock here is less prone to deep groundwater infiltration as the solution process must have an outlet to the surface to enhance karst development. The age of karst here is varied, dependent on its topographic location. The karst features that have been reported are generally confined to near-surface exposures in these bedrock units (Cooper and Mylroie, 2015). In areas such as Kingston and Rosendale in Ulster County, extensive natural cement mines were developed beginning in the early 1800s. The miners followed veins of the argillaceous (shaley) Rondout Formation limestone that in some places are inclined as much as 70 degrees from horizontal (fig. 17). Other carbonate quarries are present throughout the region, which can have variable amounts of dewatering required during the quarry production season. Evaporite karst is not present in the eastern half of New York because there are no gypsum or halite deposits present in that area (fig. 1). 
$\boldsymbol{A}$

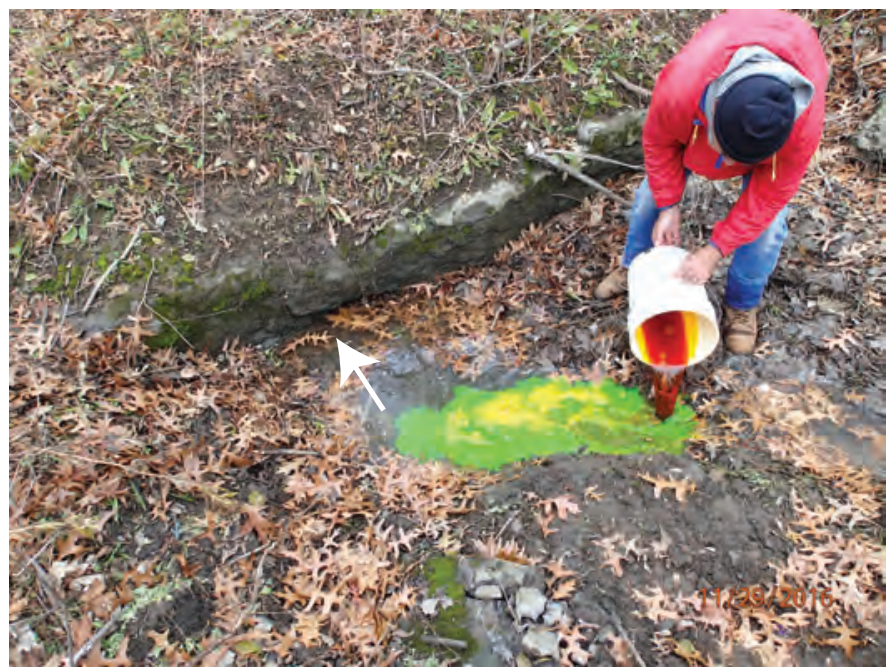

Photograph courtesy of S. Mooney, O'Brien and Gere Engineers.

$c$

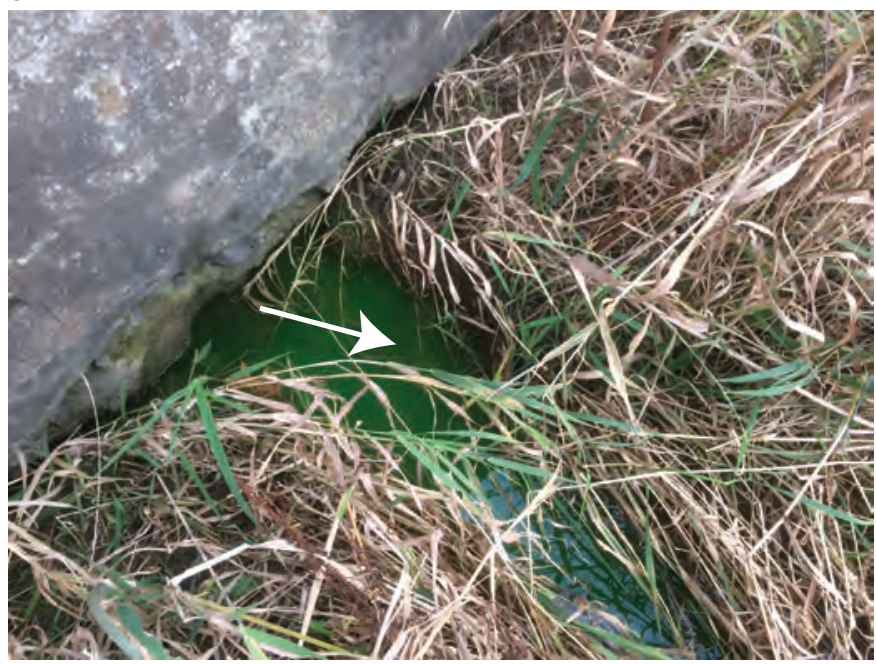

Photograph by W. Kappel, USGS
B

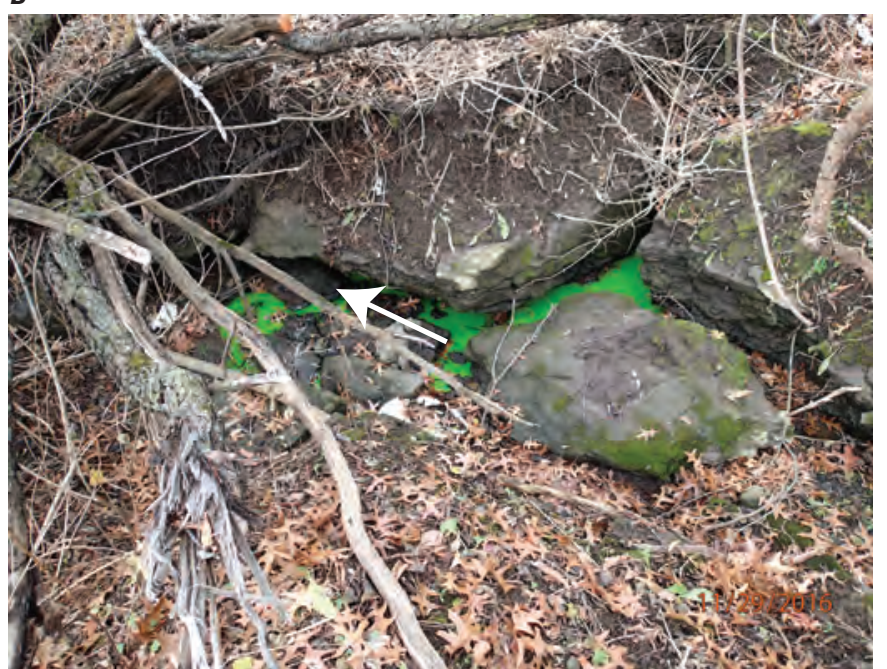

Photograph courtesy of S. Mooney, O'Brien and Gere Engineers.

D

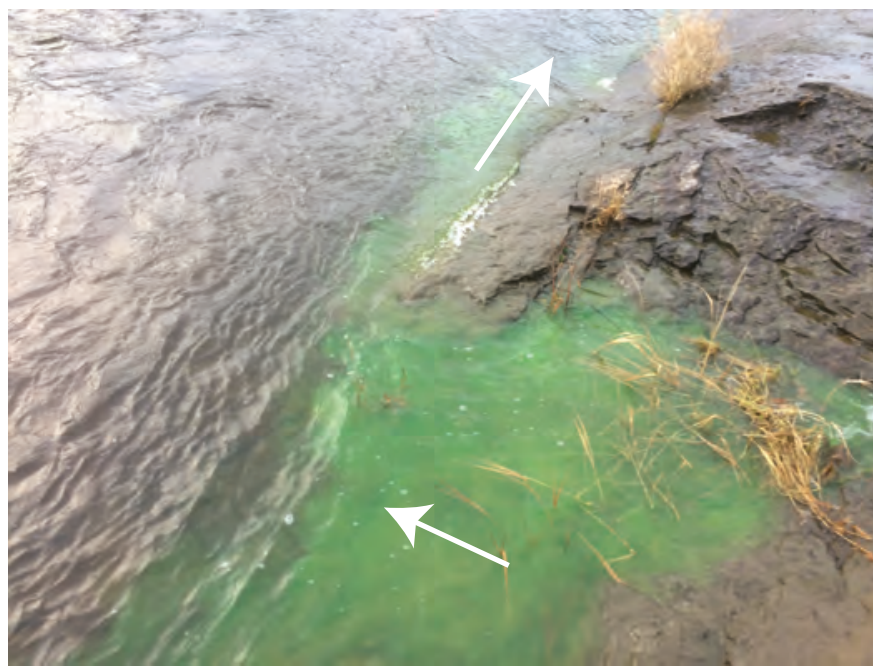

Photograph by W. Kappel, USGS

Figure 13. Dye trace in Black River Limestone, near Watertown, Jefferson County, New York. $A$, Injection of fluorescein dye into small closed depression where water flows laterally into a bedrock fracture (movement indicated by white arrows), and dye flowing $B$, in down-gradient bedrock fracture, $C$, from foundation drainpipe adjacent to the Black River, approximately 4 hours after injection, and $D$, into the Black River about 1,500 feet from dye injection point shown in $A$. 


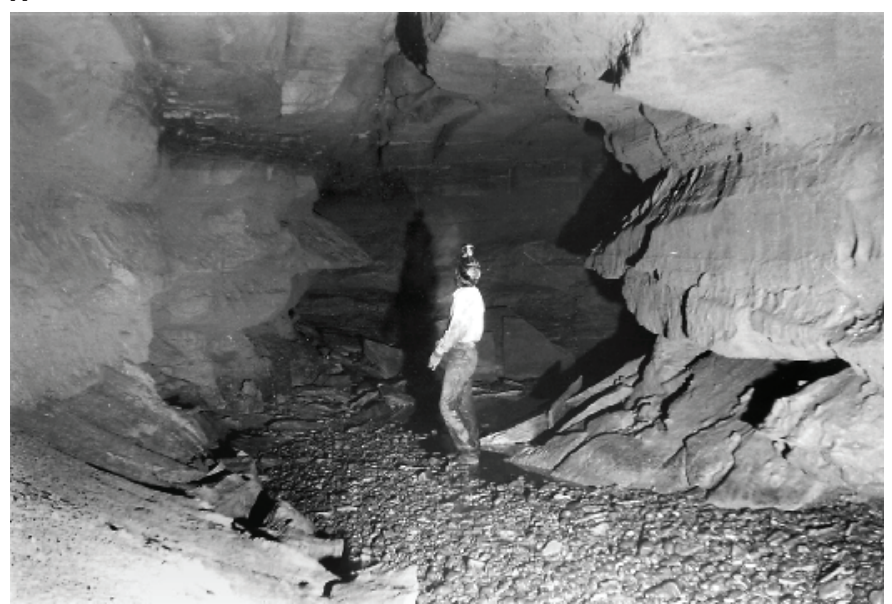

C

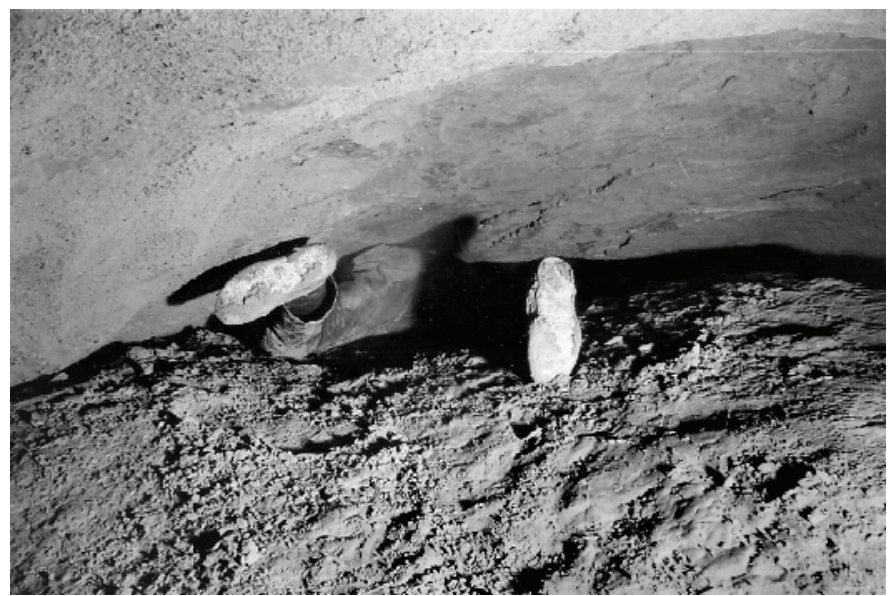

D

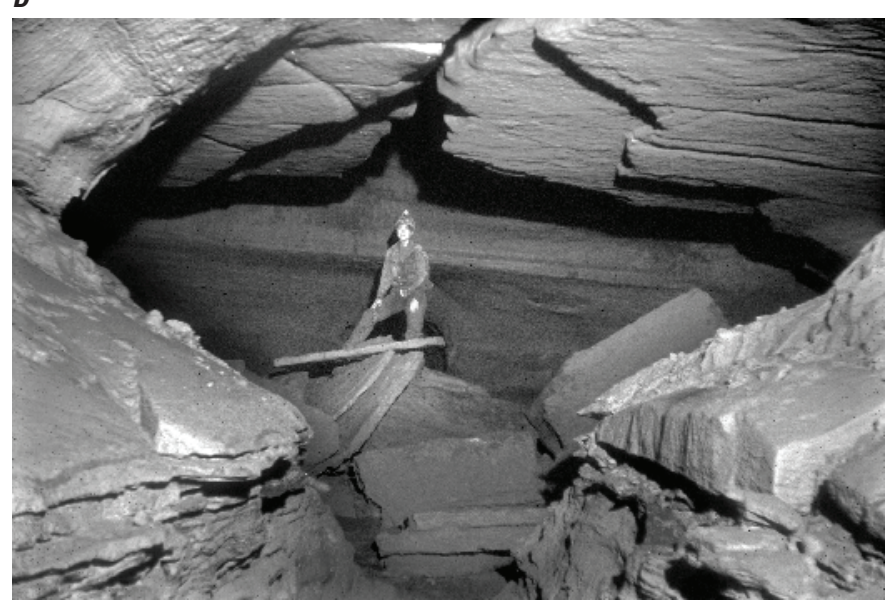

$B$

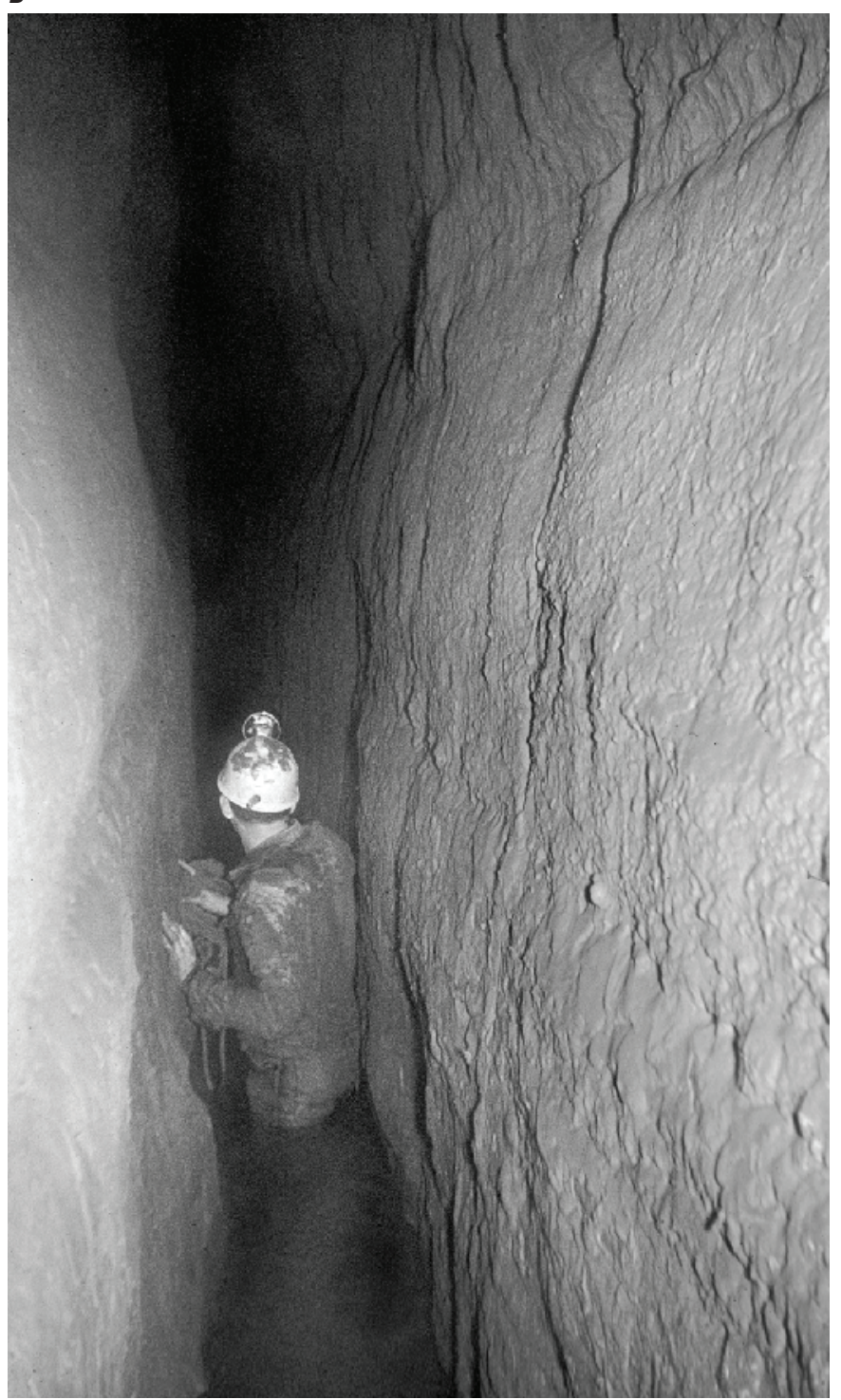

Figure 14. Cave passage features in Knox Cave in Albany County, New York. $A$ and $B$, Dissolution features in cave; $C$, glacial sediments found within most cave passages; $D$, Coeymans Limestone in the ceiling and Manlius Limestone below. Photographs courtesy of Art Palmer, professor emeritus, State University of New York at Oneonta. 
A

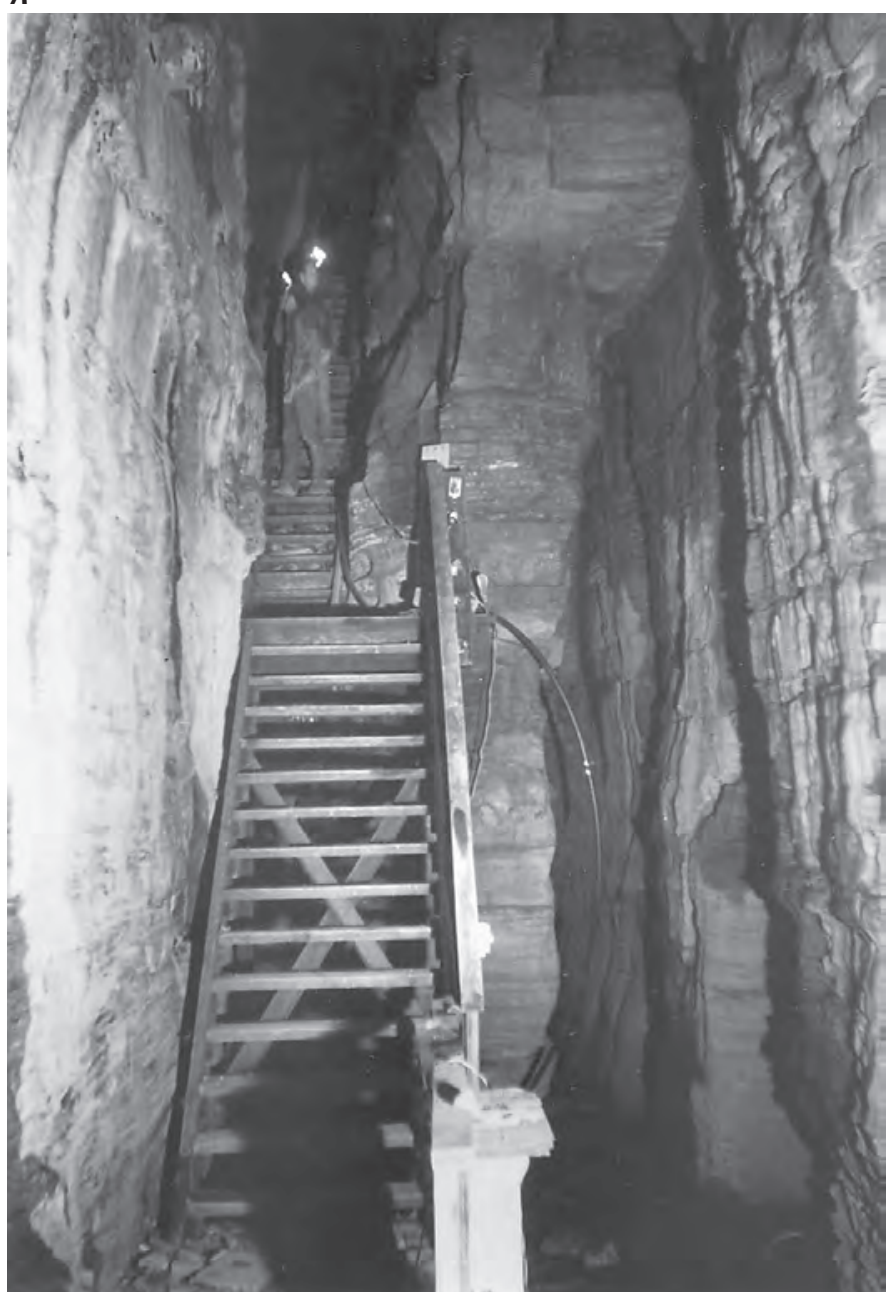

B

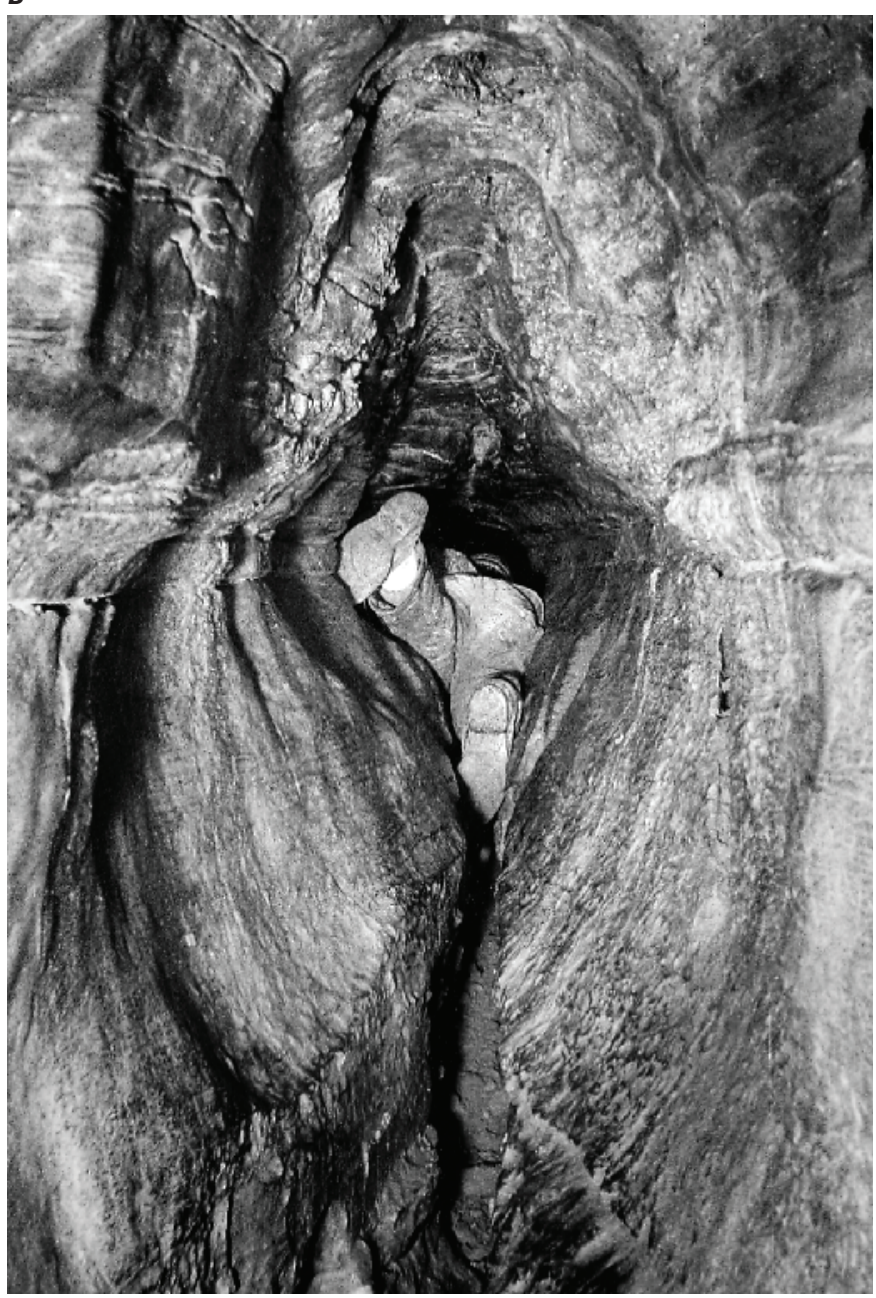

Figure 15. Features in Knox Cave in Albany County, New York. $A$, Linear passage along major joint in Manlius Limestone and $B$, the Gun Barrel cave feature along the Manlius Limestone (above) and Rondout dolomitic limestone (below) contact. Photographs courtesy of Art Palmer, professor emeritus, State University of New York at Oneonta. 

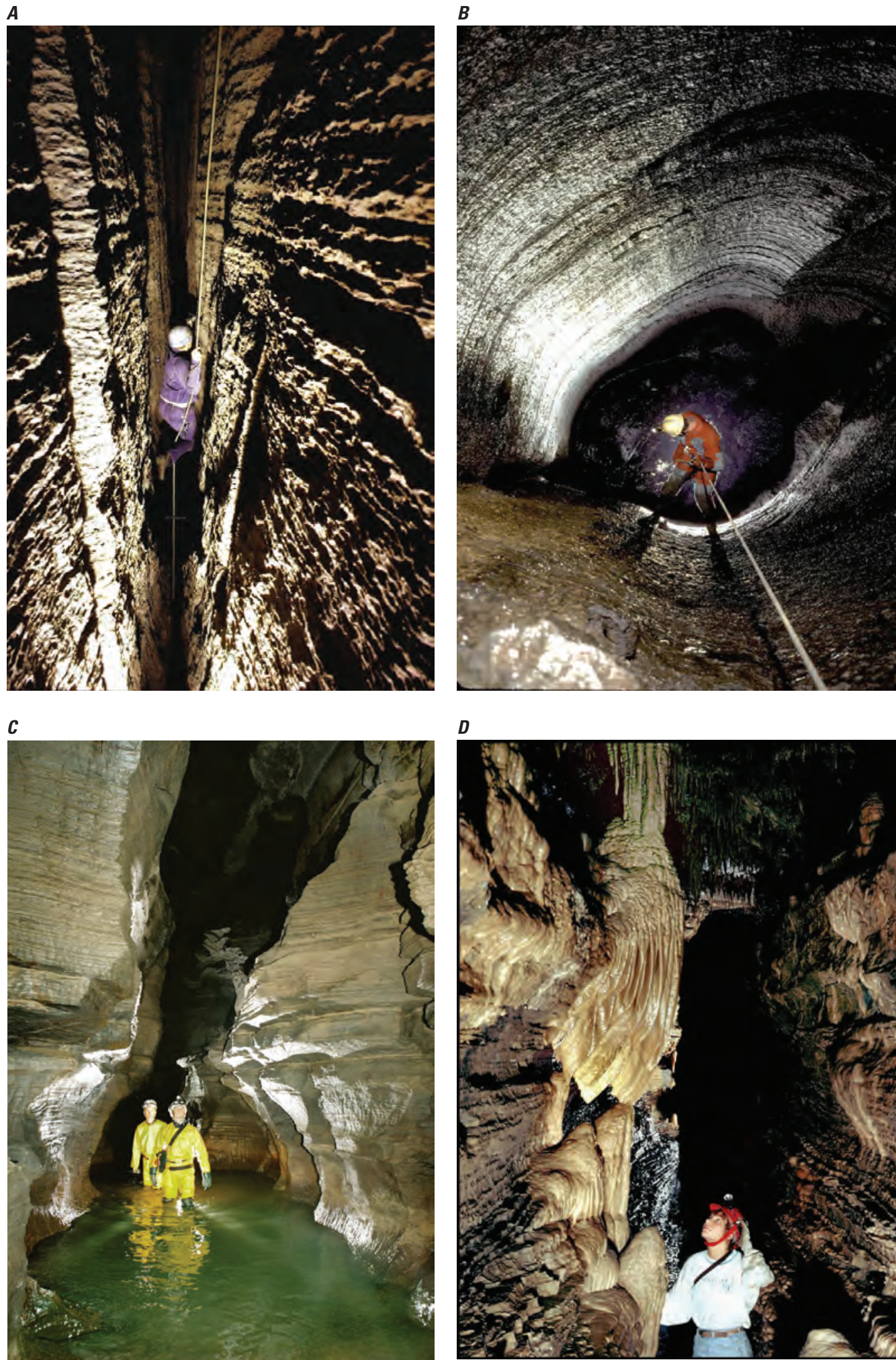

D

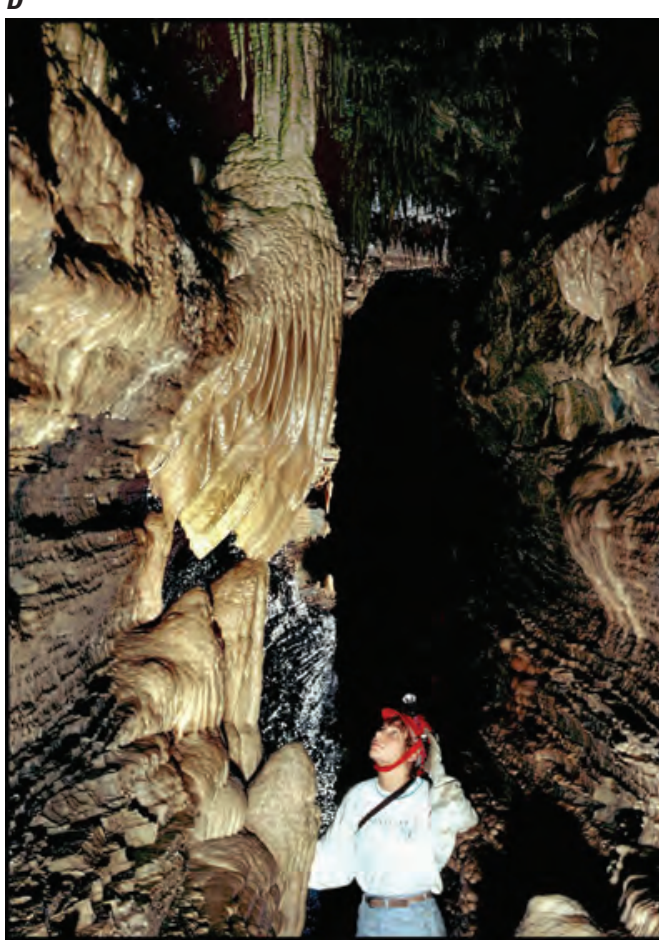

Figure 16. Cave passages from the valley of the Cobleskill Creek, a tributary to Schoharie Creek, in Schoharie County. $A$, Joint-controlled fissure passage in Coeymans Limestone; $B$, 78-foot-deep shaft enlarged by a major sinking stream, also in Coeymans Limestone; $C$, downstream passage in McFails Cave in Manlius Limestone; and $D$, calcite dripstone deposits in Manlius Limestone passageway. Photographs courtesy of Art Palmer, professor emeritus, State University of New York at Oneonta. 


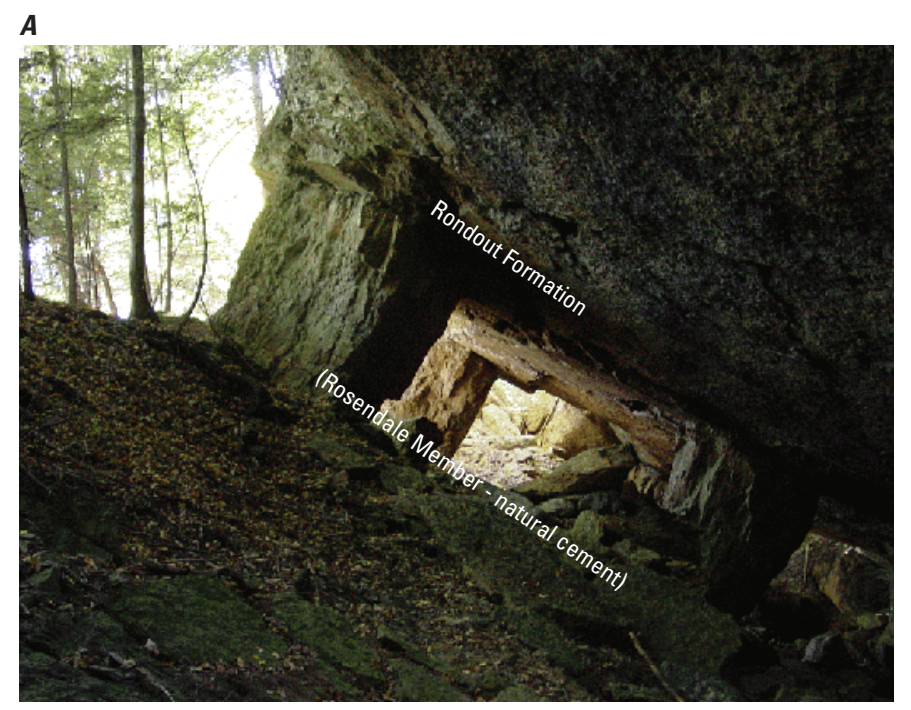

$\boldsymbol{B}$

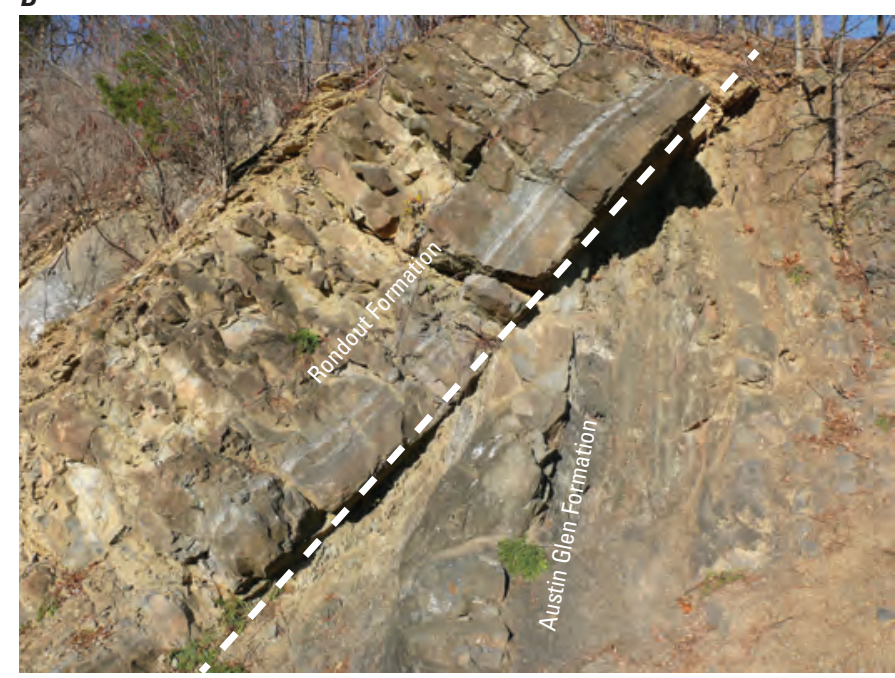

Figure 17. West side of the Hudson River Valley, New York. $A$, Entrance to a natural cement mine at Rosendale, New York, showing the dip of the bedrock; and $B$, Taconic unconformity (white dotted line) at Catskill, New York, between mid-Ordovician Austin Glen Formation and late Silurian Rondout Formation. Note the high-angled nature of the dip of both bedrock units. Photographs courtesy of Steven Schimmrich, Ulster Community College, State University of New York.

Marble of the Wappinger Group is present in the downstate region of New York into the New York City area (Inwood Marble) but other marble is present as inclusions in the Precambrian metamorphic rocks of the Adirondack Mountains in northern New York. As a result of the Acadian orogeny in the downstate area, the limestone bedrock in this region is highly deformed but the extent of marble deposits is limited (Cooper and Mylroie, 2015). During the construction of the Catskill and Delaware water-supply conduits from their respective watersheds to New York City, when borings and construction of the conduits crossed under the Rondout valley, workers encountered glacial and interglacial bedrock valleys, overthrust faults, and numerous caves and clay-filled cavities and joints, about $800 \mathrm{ft}$ below land surface. At its greatest depth, these features were below about $540 \mathrm{ft}$ of unconsolidated material and an additional $260 \mathrm{ft}$ into bedrock. In some cases, the cavities extended for vertical distances of $20 \mathrm{ft}$ or more (Fluhr, 1973). The Inwood Marble in the New York City area was also intersected during conduit construction. In some cases, during the drilling of test borings, the marble bedrock was heavily fractured and eroded to depths greater than 300 $\mathrm{ft}$, and a substantial amount of water had to be grouted or otherwise removed to allow for construction of the conduits (Fluhr and Terenzio, 1984). The deep karst development noted in Fluhr (1973) and Fluhr and Terenzio (1984) likely formed when glaciers were active and the high hydraulic pressure at the glacial ice-bedrock interface created ideal conditions for karst development. During deglaciation, thick sequences of glacial sediments were deposited, especially in the deeper bedrock valleys, possibly slowing karst development unless there was an active flow system to continue the karst development process.

\section{Previous U.S. Geological Survey Karst Studies in New York}

In the early 1980s, the USGS, in cooperation with the Erie County Department of Environment and Planning, monitored groundwater-level declines in a 2.2-mi-long by $800-\mathrm{ft}-$ wide closed depression area in eastern Erie County (Staubitz and Miller, 1987; fig. 18). More than 60 domestic water wells and several wetlands went dry and several new sinkholes developed or expanded. The water-level decline was caused by the combination of groundwater withdrawal at a limestone quarry and the diversion of that water away from a downgradient sinkhole-swallet in the eastern end of the large closed depression. The routing of the quarry water away from the former receiving swallet to an adjacent surface-water stream removed the allogenic recharge from the closed depression's groundwater watershed west of the quarry and caused the water-level declines noted in many homeowner wells within the depression further to the west.

In 2008, the USGS, in cooperation with the NYSDEC, initiated a pilot study to characterize the recharge settings of the carbonate karst in Genesee County in western New York (fig. 1) after a number of groundwater contamination issues were reported during the previous decade (Reddy and Kappel, 2010). Gently dipping Onondaga Limestone is present as an east-west band across Genesee County. The Onondaga Limestone crops out to the north along an escarpment and a 2- to 5-mi-wide band of the limestone is covered by glacial deposits to the south. A series of 1:24,000-scale maps was constructed and showed areas where focused recharge can most readily infiltrate into the karst carbonate bedrock and potentially contaminate the groundwater-flow system (Reddy 


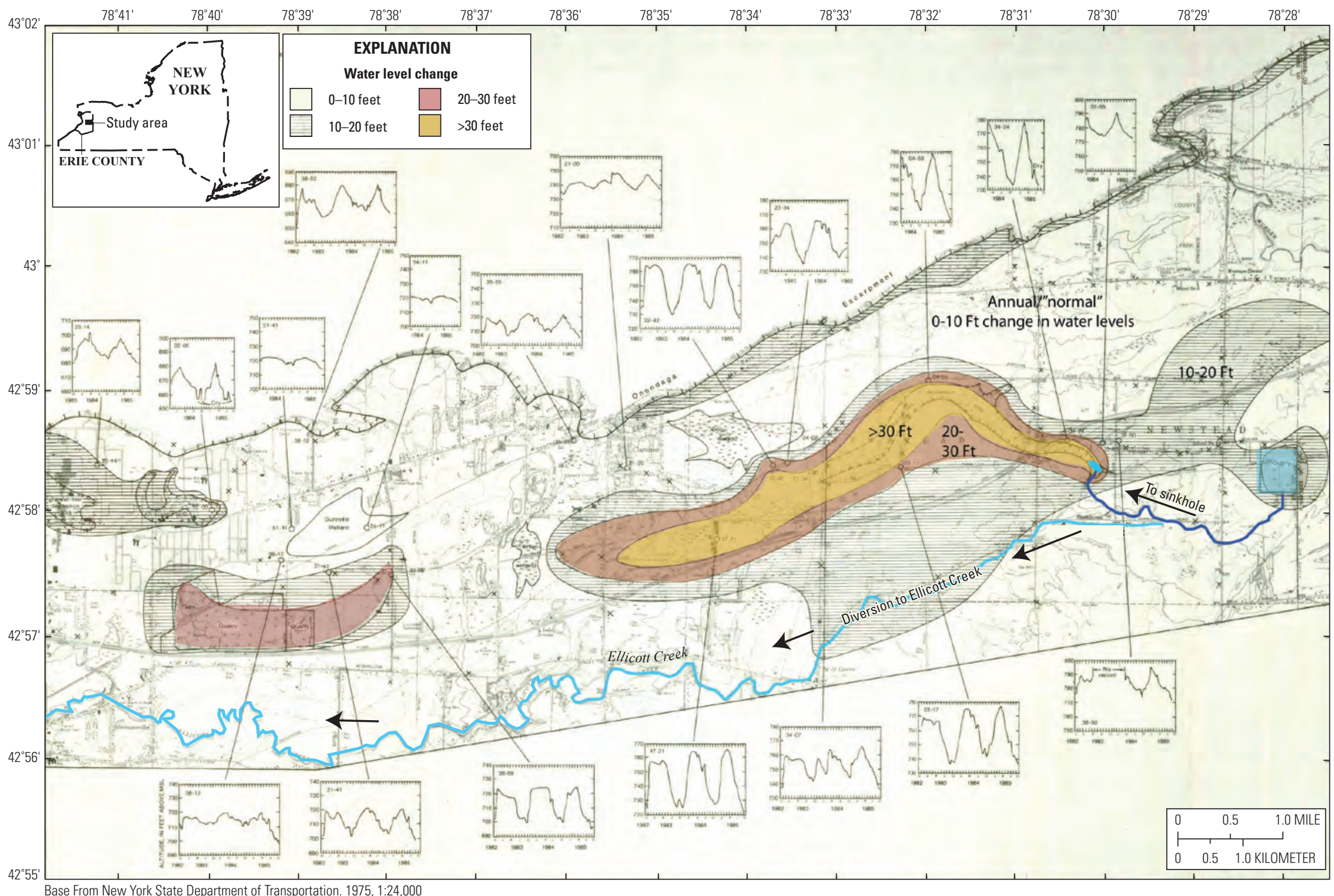

Figure 18. Decline in water levels in a large closed depression, western New York, from April 1981 to October 1985, indicating the effect of diverting quarry dewatering flow from a downstream sinkhole-swallet to Ellicott Creek; modified from Staubitz and Miller (1986, pl. 4). This diversion removed groundwater from the downstream sinkhole, which caused water-level declines greater than 30 feet in some down-gradient homeowner drinking-water wells. 
and Kappel, 2010). Evaporite karst (shale with gypsum) north of the Onondaga Limestone escarpment was not characterized in that study. Using information from the USGS study of Genesee County, Cornell University and the NYSDEC developed manure management guidelines for karst areas in the county, including where concentrated animal feedlot operations were applying manure within karst areas of the County (Czymmek and others, 2011).

The same manure-management practices have been encouraged in other parts of State where the risk of applying manure may impact surface-water and groundwater resources. For example, Madison County (in central New York) has utilized these same manure-management criteria and several other counties in New York have considered following these guidelines to better protect their groundwater resources where karst is present (Karl Czymmek, Cornell University, oral commun., February 2017). Any farm that has a concentrated animal feedlot operation permit is required to follow these or previously designated guidelines to protect groundwater (New York State Department of Environmental Conservation, 2017b).

Between 2001 and 2011, the USGS, in cooperation with the U.S. Environmental Protection Agency (EPA), assisted with a study of volatile-organic compound contamination in the carbonate-bedrock aquifer system in Cayuga County between Auburn and Union Springs (a distance of $7 \mathrm{mi}$; Eckhardt and others, 2011). The USGS collected and compiled geophysical logs from 93 monitor and water-supply wells in the carbonate-bedrock aquifer between Owasco and Cayuga Lakes, two of central New York's Finger Lakes. The USGS analyzed geophysical logs along with core samples from drilled bedrock wells, inspected outcrops of the bedrock to define the stratigraphic units penetrated by wells, evaluated flow zones within the bedrock aquifers, and developed and installed multilevel monitoring systems for the study (U.S. Environmental Protection Agency, 2012). The USGS also assisted the EPA in a similar fashion in western New York near the town of LeRoy in northeastern Genesee County. In 1970, a railroad tanker car derailment spilled thousands of gallons of trichloroethylene into the local carbonate bedrock (Onondaga Limestone), contaminating drinking water wells (U.S. Environmental Protection Agency, 2017).

\section{Karst Development in New York}

The development of karst is variable across New York but is generally related to the geologic characteristics of the rock (carbonate versus evaporite), the quantity and quality of water that the rock is exposed to, and the length of time that the karst process has been occurring. The repeated glaciation of New York has assisted with karst development as glaciers have removed overburden and injected water directly into bedrock, enhancing karst development. However, at the same time, repeated glaciation has destroyed former karst systems by eroding the karstic bedrock and creating a postglacial environment to start the karst-forming process once again.

\section{Western and Central New York}

In western and central New York, the gently southward dipping Onondaga Limestone and Lockport Group dolostone have young or early karst features, especially near their escarpments. Apparently during glacial advance, former escarpments were heavily eroded back to more competent bedrock, and the new escarpment initially had limited karst development. The land surface downgradient from each escarpment was usually mantled by glacial and postglacial sediments, which limited karst development until glacial rebound occurred, allowing the dissolution of bedrock joints and fractures as these features opened due to the land-surface rebound processes. The Onondaga Limestone is more prone to karst development than the dolostone of the Lockport Group because of its different geochemical composition. Although karst solution features are present in both units, the Onondaga has more well-developed karst flow systems (large closed depressions, early conduit-cave development, and sinkholerelated subsidence) than the Lockport Group (Staubitz and Miller, 1987). For example, in the town of Clarence (Erie County), a bowling alley was built in the early 1960s on a farm property known as "The Sinks" (The Clarence Museum, written commun., February 2017). The building collapsed into a sinkhole in the early 1980s, and reportedly, a section of New York State Route 5 in front of the bowling alley also slightly subsided at the same time, although the subsidence did not close the roadway. The remaining part of the bowling alley building was demolished, the sinkhole filled, and the site today [2020] remains undeveloped. Although both the Onondaga and Lockport bedrock units have some solution channel and modest cave development, these features more commonly occur near their escarpments and along adjacent steep erosional features (such as along the Niagara River gorge), but as indicated in the bowling alley story, solution features (sinkholes, closed depressions) have occurred elsewhere in the karstic rock.

Just north of the Onondaga Limestone escarpment, gypsum deposits are present within the underlying Salina Group shales (fig. 1). Karstification developed where gypsum deposits are close to the land surface and, in some cases, over former gypsum mines. In western New York, thin beds of gypsum ( 3 to $5 \mathrm{ft}$ thick) have experienced extensive gypsum mining from the 1800s through the late 1990s. The extent of these mines is roughly from the Clarence area in Erie County eastward through parts of Genesee County to the southwestern part of Monroe County, in the Garbutt area. From Garbutt to just east of Syracuse (Onondaga and Madison Counties), gypsum was obtained from shallow open-pit quarries as the gypsum seams are discontinuous in this part of the State and more easily accessed from the land surface. 
Where these former subsurface mines were developed, dissolution of the remaining gypsum support pillars or partial collapse of the mine roof has led to some land-surface subsidence and closed depression development. A number of geologic studies were performed in the town of Clarence, but north of the Onondaga Limestone escarpment, between 1972 and 1989 to determine whether residential and commercial development could occur over a part of the former National Gypsum Company mine (HydroTech Ground Water Consultants, 1989). A summary of these various studies indicated that future sinkhole development was possible because several sinkholes were already present over the mine in 1972, but the timing and extent of such development was difficult to quantify. The site over the former gypsum mine and other places nearby have since been fully developed.

In the town of Wheatland in southwestern Monroe County, the 460-acre Oatka Creek Park is maintained for hiking and cross-country running and skiing along $6.5 \mathrm{mi}$ of trail. In the late 1990s, the USGS was asked why the land surface of the park was experiencing subsidence. A surface examination of the park revealed linear subsidence patterns generally aligned in a north-south direction. A search of the town's history (Schmidt, 1953) and a summary of gypsum resources in New York State (Newland, 1929) revealed that there were at least three former gypsum mines along the southern side of Oatka Creek in this part of the county. The mines had exploited gypsum seams that surfaced along the southern side of Oatka Creek near stream level and mine adits (dipping-tothe-south tunnels) were dug to remove the gypsum. In this case, the present-day park was built over the former Garbutt Gypsum Mine, which utilized such adits (Schmidt, 1953). Subsequent to these findings, the Monroe County Parks Department contracted with a private firm to perform a geophysical (electrical resistivity) survey to confirm the location of the adits. Results of the Oatka Creek Park survey indicated "the presence of numerous sinkhole and subsidence features related to either collapsed shafts [that is, subsidence features related to the bedrock collapse over the trend of the adits] or open-pit mining of gypsum near Oatka Creek" (Forrest Environmental Services, Inc., 2001, p. 2).

As a result of the amount of former gypsum mining in Wheatland, a mine subsidence hazard district was created as a zoning overlay. The stated purpose of the district was, in part, "[i]n the interest of the public health, safety, and welfare, these regulations are intended to protect development located in an area in the Town of Wheatland that has been subjected to underground mining, with much of such area [sic] not provided with maps of the undermining. More specifically, the purpose of these supplementary controls is to prevent the erection of habitable structures in an area that could be unsafe due to undermining, to minimize danger to public health...... due to subsidence" (Town of Wheatland, 2015).

In central and eastern New York (east of Rochester), the gypsum beds become thin to nonexistent because gypsum is present only as pockets and lenses (Tennissen, 1952), which were mined from the land surface. Though these pockets are considered small, apparently some land-surface subsidence has occurred, although such subsidence has been reported in just a few areas. For instance, in Syracuse in Onondaga County, gypsum dissolution may have caused nearly $30 \mathrm{ft}$ of landsurface subsidence since the last period of glaciation, about 12,000 years ago (Phillips, 1955). Such gypsum-dissolution subsidence likely occurred elsewhere within these limited gypsum deposits, but without substantial urban development, land-surface subsidence may not have been noticed other than possible development of isolated sinkholes or closed depressions, some of which may have developed into wetland areas. In the Syracuse area, sinkhole and subsidence have been reported, and in one case, an investigation of the local geology revealed the presence of a heavily weathered shale zone at the bedrock surface and a vertical zone of heavily weathered gypsiferous shale within surrounding unweathered shale that has anhydrite- and gypsum-bearing seams and inclusions (fig. 19) similar to what was indicated by Phillips (1955).

The Salina Group, and in particular the Syracuse Formation, contains beds of halite (rock salt) interbedded with shale (fig. 1). Near the outcrop of the Salina Group at land surface, any halite that may have been present was easily removed by dissolution during and following glacial periods when meltwater was likely forced into the heavily fractured rock by the overburden pressure of the glacier, dissolving halite that interacted with the injected water (Goodman and others, 2011). Any subsidence related to this solution process happened at that time and is of little concern presently. But halite has been and continues to be mined in the subsurface either by solution- or hard-rock-mining techniques in central New York, well to the south of the former outcrop area. There have been cases of land-surface subsidence related to both forms of halite mining. Though the extent of subsidence is locally important — such as subsidence from solution-well mining in the Tully Valley near Syracuse (Hackett and others, 2009) or room-and-pillar mining of halite in the Genesee Valley south of Rochester (Yager and others, 2012) - these types of halite-related subsidence are not extensive across the central and western part of the State.

\section{Northern New York}

In northern New York and along the western side of the Adirondack Mountains, strata of the Black River and Trenton Groups are nearly flat lying and have been fractured due to glacial advance and recession and continued tectonic doming of the Adirondack Mountains (Isachsen, 1981). Karst development in this bedrock unit is considered young as it is primarily influenced by recent glaciation and its proximity to flowing surface water and the zone of annual groundwater fluctuation (Waller and Ayer, 1975). In the vicinity of Watertown, the limestone of the Black River Group has karst features and "a vast network of caverns of varying heights and expanses with intricate ramifications and labyrinthine corridors [sic] 


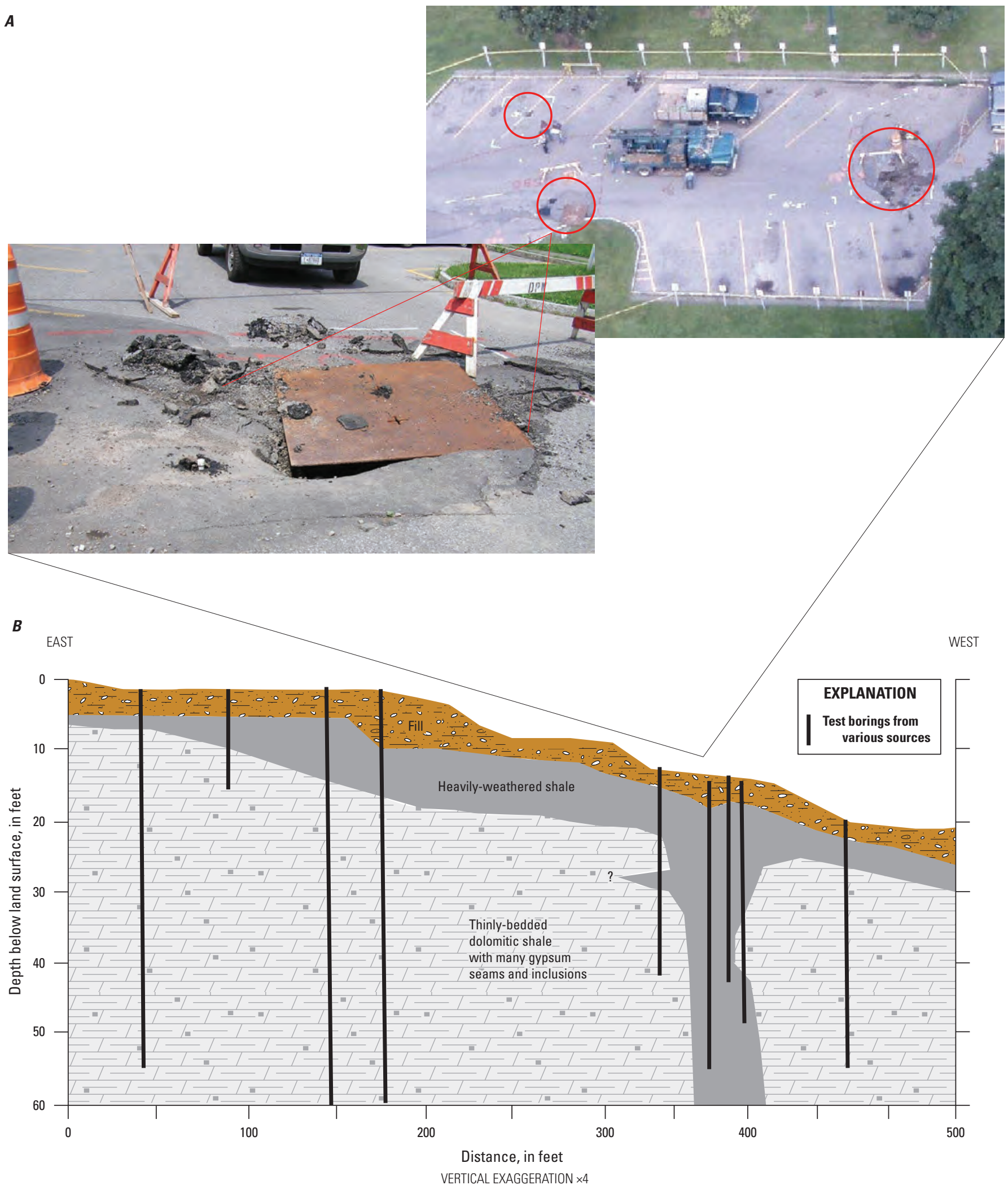

Figure 19. Sinkhole development in evaporite karst bedrock in Syracuse, Onondaga County, New York. A, Parking lot subsidence (red circles) in area where deeply solutioned bedrock is present, and closeup of surface area of one of the sinkholes. $B$, Schematic cross section of the depth to heavily weathered shale and more competent shale with gypsum seams and inclusions beneath, and a deep zone of gypsum-solutioned bedrock where continual land-surface subsidence (shown in $A$ ) has occurred. 
occupy the thick and expansive deposit of limestone over which the city of Watertown has been built" (Northern New York Genealogy, 2001). Some of the caves of various sizes and lengths were used to store beer during the summer season, another cave was an attraction for a local amusement park where cave boat tours were given, and several caves in Watertown were considered for use as bomb shelters during the Second World War. Of note is that the entrances to all these caves are presently [2020] sealed.

The Trenton Group, which overlies the Black River Group, does have some vertical fracturing but is less prone to karst development because of its chemical makeup: an argillaceous (shaley) limestone with thin limestone interlayered with shale throughout the Trenton sequence. The Beekmantown Group, primarily in northern New York but also present along the east side of the Adirondack Mountains (fig. 1), is mostly composed of dolostone with interbedded limestone and sandstone. Where the Beekmantown bedrock is near the land surface, it has been weathered and fractured by glacial advance and retreat (glacial rebound), which does enhance some karstic development. This is especially the case where the bedrock is associated with underlying dolostone or permeable sandstone, which allows surface water to move through an upper dolostone layer to a point of discharge or into a deeper bedrock flow system. Some limestone in this region has also been metamorphosed into small bands of marble that also exhibit karstic attributes.

\section{Eastern and Southeastern New York}

Karst in eastern New York is well developed because of the great thicknesses of carbonate bedrock (Onondaga and Helderberg Group) and the extended period of time in which the bedrock has been exposed to repeated glaciation and interglacial erosion, especially in the eastern Mohawk River basin (Baker, 1976; Cooper and Mylroie, 2015). Because of the presence of this well-developed karst, several studies have linked karst and the need to protect groundwater from contamination. "These [karst] features complicate the flow of ground water and create special problems regarding water supply. Due to thin soils, there is a potential for widespread ground water contamination and a limited ability to support foundations and building loads. There are few regulatory controls devoted to protecting karst areas" (Schoharie Planning and Development Agency, 2002).

A study of the Cobleskill Plateau by Braun (2000, p. 62-63) indicated that "Of the 40 wells for which chemical analysis was available, 87.5 percent showed some level of contamination from nitrates and 82.5 percent contained phosphates... Of the 43 wells tested for bacteria using a presence or absence test, 81.4 percent showed a presence. These figures indicate a strong degree of interaction of surface water with well water on the limestone plateau. All the wells [tested] on the Cobleskill Plateau are located in an area where dairy farming is the number one industry. One of the wells, which had high nitrate levels, had raw manure coming through the water system.....as reported by the homeowner. The well drew water from $116 \mathrm{ft}$ below the surface [likely the location of the well pump, as the water level in the well was not noted]. Adjacent to the house are crop fields where sinkholes form and are filled with fieldstone... The fieldstones fill the sinkholes, but they do not seal the sinkholes, which have a direct connection with groundwater."

The Helderberg-Cobleskill Plateau region (Baker, 1976; Palmer and others, 2003; Cooper and Mylroie, 2015) is an incised carbonate terrain resulting from repeated periods of glaciation and erosion, which, over time, has created solutionderived fracture conduits and well-developed cave systems (figs. 14, 15, and 16). The glacial and interglacial processes bisected the land surface to create a number of hydraulically isolated carbonate rock "islands" where vertical bedrock joints and sinkholes intersected south-dipping bedding planes to create a classic karst topography: upgradient losing streams and swallets flowing to downgradient springs, some of which might exhibit artesian flow where former, lower spring outlets were blocked by more recent glacial debris (Palmer and others, 2003). The area of Schoharie, Albany and Greene Counties (Helderberg-Cobleskill plateau) has the oldest known and largest number of well-developed, most-explored, and documented cave systems in New York (fig. 20). Many of these cave systems have been mapped, and some cave-catchment areas have been defined using dye tracing techniques.

Further downstate, along the western side of the Hudson River valley, the Onondaga and Helderberg Groups exhibit localized karst development. A study of the New York City water supply conduit flowing from the Rondout Reservoir through the West Branch Tunnel under Wawarsing (fig. 21) indicated a hydraulic connection between the unlined conduit and the overlying bedrock and near-surface unconsolidated aquifers (Stumm and others, 2012). During construction of the West Branch Tunnel, this section of the tunnel was observed to have been highly faulted and weathered, had inflow of more than 9,000 gallons per minute, and required more than 20,000 bags of concrete and steel reinforcements to stabilize the bedrock (Stumm and others, 2012). This condition indicates fracture solutioning and enhanced permeability within the carbonate bedrock and was likely influenced by the active geologic history of the Hudson River valley creating extensive faulting within the bedrock.

Along Interstate 87 (New York State Thruway) near the city of Saugerties in Ulster County, the use of road salt on the interstate highway has apparently affected a number of homeowner wells that were drilled into the steeply dipping Onondaga Limestone. A nearby water line was extended to these homes to resolve the problem (Paul Rubin, HydroQuest, written commun., January 2016).

There is a number of named cave systems in this region (fig. 20) but far fewer than in the same bedrock units just to the north. Further south, the Inwood Marble also exhibits some karst features, although the amount of karst is limited 


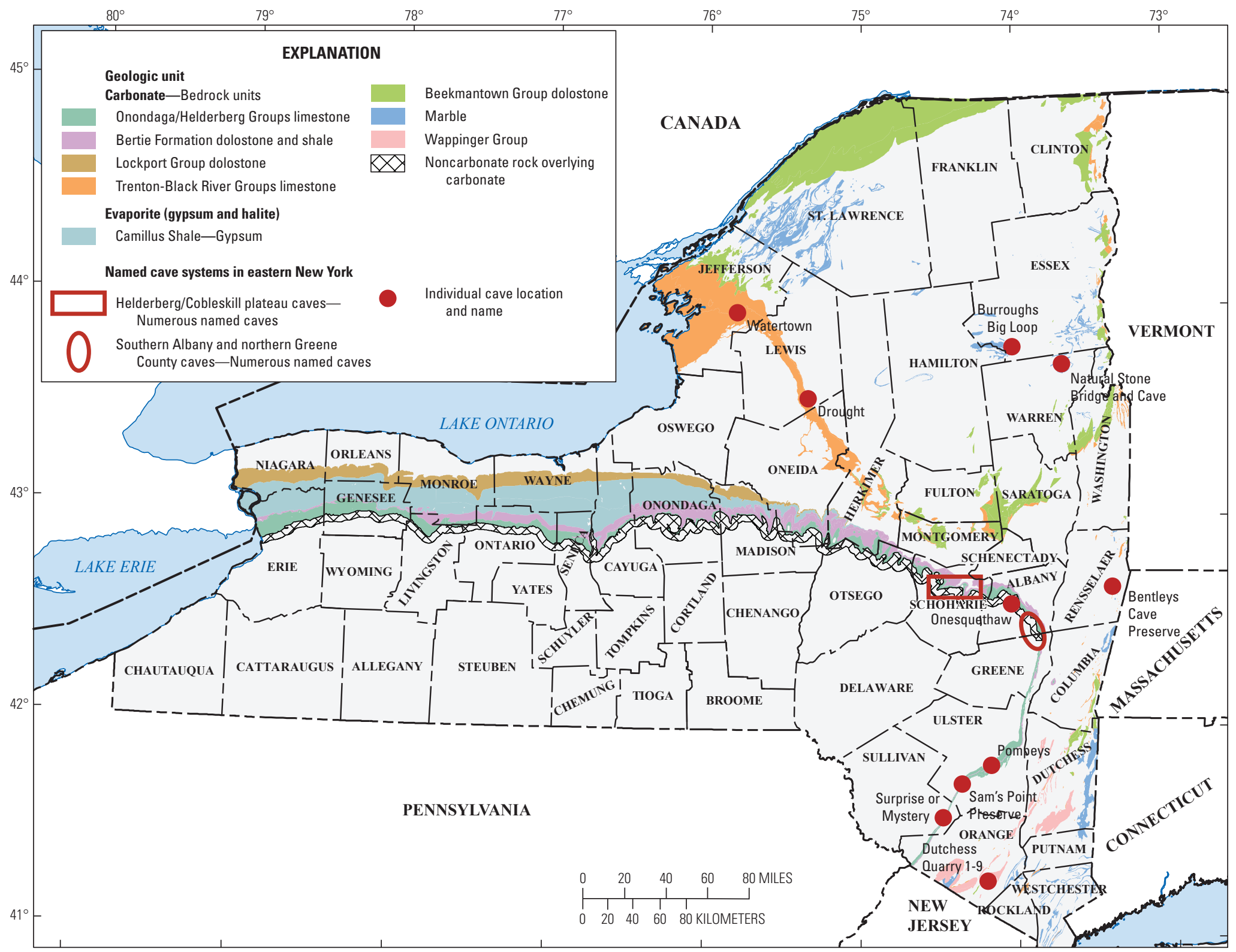

Figure 20. Selected named cave systems in eastern New York. 
${ }^{A}$

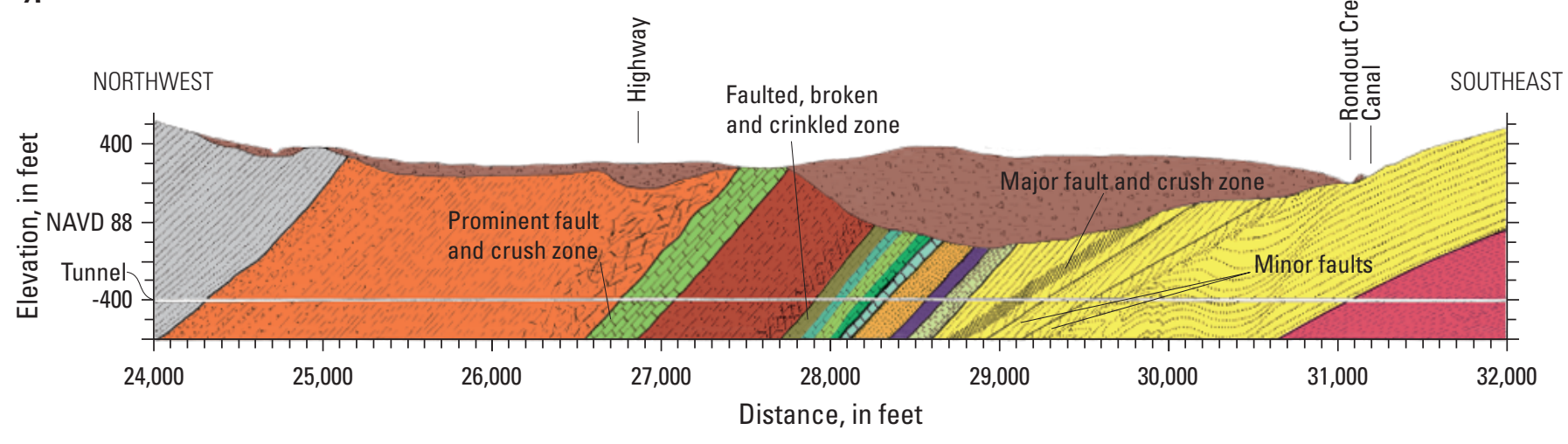

EXPLANATION

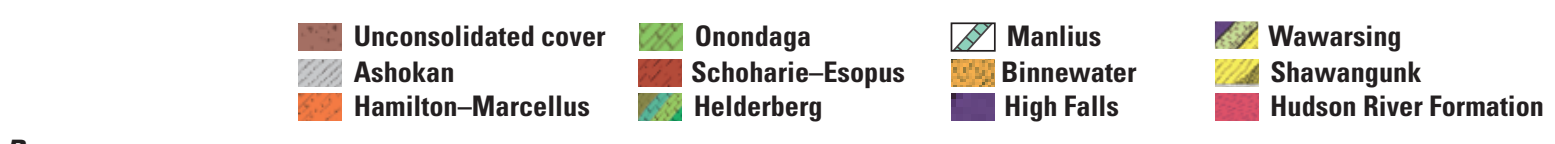

$\boldsymbol{B}$

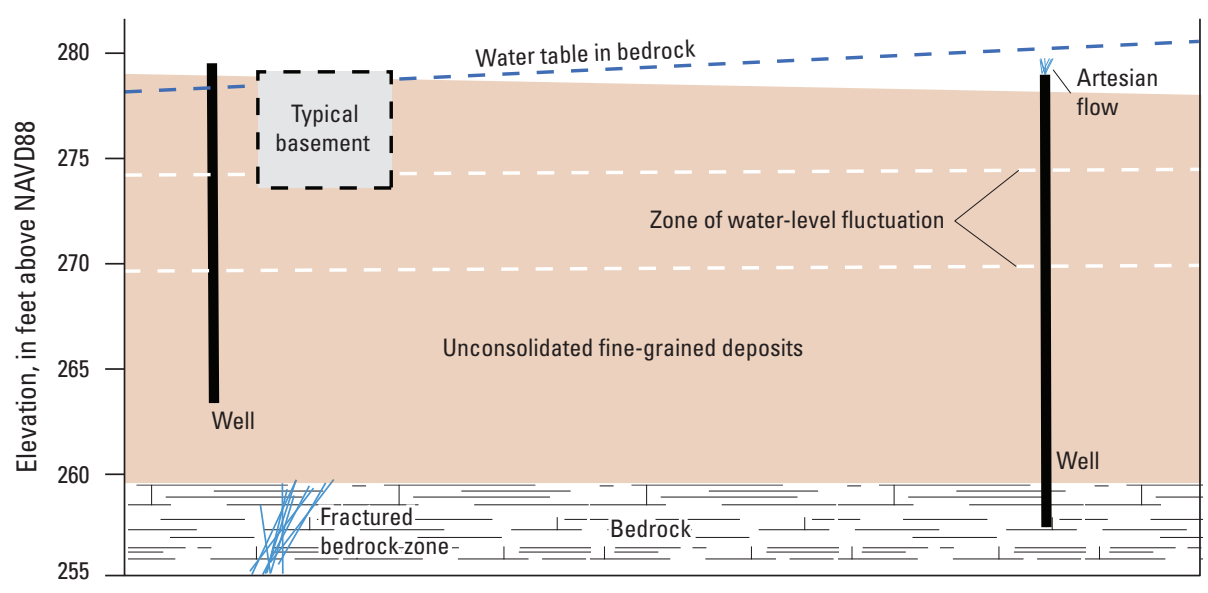

D
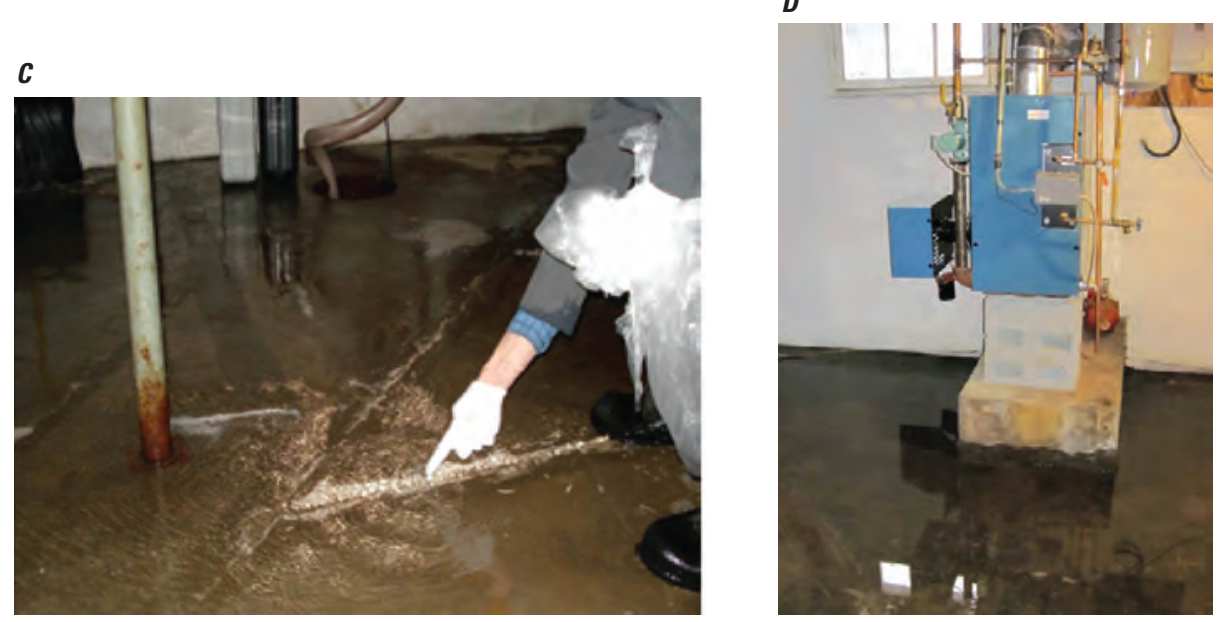

Figure 21. Hydrogeologic conditions at Wawarsing in Ulster County, New York. A, Geologic cross section for the Rondout tunnel near Wawarsing, showing bedrock types and fracture-fault locations; modified from Stumm and others (2012); $B$, schematic section of the water-table configuration for unconsolidated and bedrock aquifers. $C$ and $D$, Flowing artesian conditions in flooded Wawarsing area basements; from Stumm and others (2012). NAVD 88, North American Vertical Datum of 1988. 
by the small extent of the formation and the amount of urban development that has obscured the expression of karst features at land surface.

\section{Closed-Depression and Focused-Recharge Inventory}

The objective of the geographic information system (GIS) closed-depression and focused-recharge analyses conducted for this study was to develop a comprehensive inventory of all closed depressions proximal to carbonate, evaporite, or marble units within the State. The distribution of these bedrock units in New York form the basis of the study area. The inventory is restricted to an area defined by bedrock lithologies where karst is known to be present. However, no inference can be made that a mapped closed depression is karstic in origin. Individual evaluation of each inventoried depression would need to be conducted to determine the processes that created the feature. That level of effort is beyond the scope of this study.

A closed depression is defined as an enclosed area lower than the surrounding area that has no surface-drainage outlet and from which water escapes only by evaporation or subsurface drainage (that is, an area of focused recharge). On USGS topographic maps, a closed depression is indicated by a hachured contour line forming a closed loop (Natural Resources Conservation Service, 2017). Examples of closed depressions in a karst area are shown in figure 22. The map representation applies to closed depressions of both natural and anthropogenic origin. Many of the closed depressions

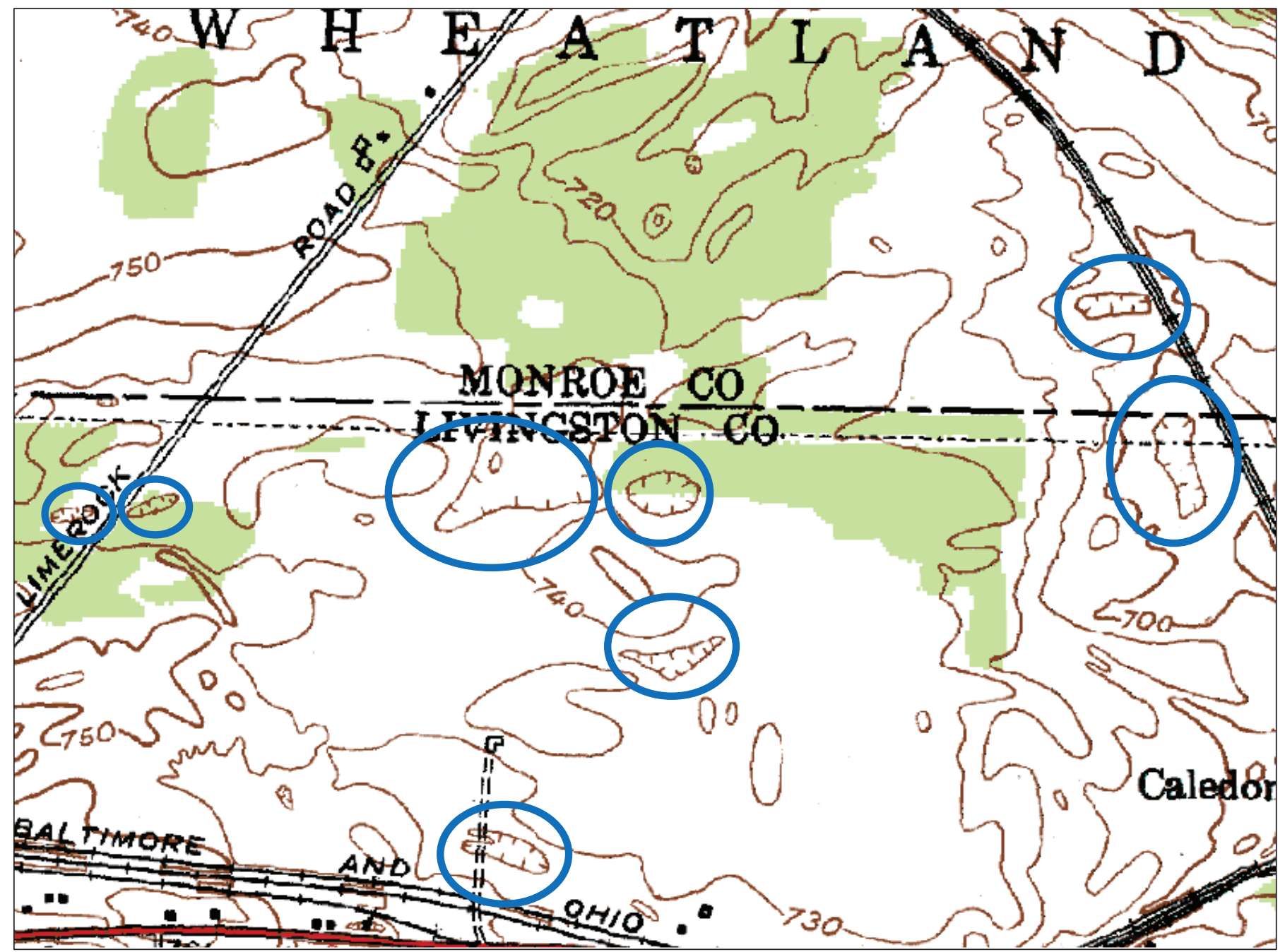

Figure 22. Examples of closed depressions as they appear on a topographic map; modified from U.S. Geological Survey (1950). Closed depressions are indicated within blue circles. 
included in this inventory, though not the result of karst processes, are within or adjacent to a karst landscape and could contribute to focused recharge.

\section{Study Area}

The study area boundary adopted for the GIS analyses was created by intersecting an index of USGS 1:24,000-scale, 7.5-minute quadrangle maps (U.S. Geological Survey, 2014) with data containing selected bedrock geologic units (table 2; Horton and others, 2017). The final study area boundary covers more than 20,000 square miles, equivalent to 38 percent of New York State and transecting 42 counties (fig. 23).

\section{Data Sources}

Data acquired for the GIS analyses can be grouped into two categories: (1) source data for identifying closed depressions and (2) ancillary data used to assign geologic, soil, and land cover characteristics to the inventoried closed depressions (table 3). The spatial relation between ancillary characteristics and closed depressions can be used to assess which closed depressions have a greater potential for contributing focused recharge.

\section{Closed Depressions}

The closed depressions were derived from three data sources and were compiled in the following order: (1) digital contour database of closed depressions, (2) digital raster graphic database of closed depressions, and (3) light detection and ranging (lidar) database of closed depressions. All three databases are from Reddy and others (2020). There is no duplication of features among the three databases. Additionally, the closed depressions inventoried were compared with closed depressions mapped in other published geospatial data to eliminate duplication with those datasets. The datasets referenced were New York State Department of Environmental Conservation (2017a) and U.S. Geological Survey (2013).

Table 2. Reclassified bedrock geologic units for karst aquifers in New York.

[Geologic units are from Horton and others (2017). —, not designated]

\begin{tabular}{|c|c|c|c|}
\hline Major unit 1 & Major unit 2 & Major unit 3 & Formation or unit name \\
\hline \multicolumn{4}{|c|}{ Onondaga } \\
\hline Limestone & Chert & Shale; conglomerate & Glenerie Formation \\
\hline Sandstone & Limestone & - & Oriskany Formation \\
\hline Limestone & Sandstone & Chert & Onondaga and Bois Blanc Limestones \\
\hline Limestone & Chert & - & Onondaga Limestone \\
\hline Shale & Limestone & Siltstone & Onondaga Limestone \\
\hline Limestone & Dolostone (dolomite) & $\begin{array}{l}\text { Sandstone; shale; conglom- } \\
\text { erate }\end{array}$ & Undifferentiated Lower Devonian and Silurian rocks \\
\hline Siltstone & Limestone & $\begin{array}{l}\text { Sandstone; dolostone (dolo- } \\
\text { mite); shale }\end{array}$ & Rondout Formation \\
\hline \multicolumn{4}{|c|}{ Akron } \\
\hline Limestone & Dolostone (dolomite) & - & Helderberg Group \\
\hline $\begin{array}{l}\text { Dolostone } \\
\quad \text { (dolomite) }\end{array}$ & Shale & - & Akron Dolostone \\
\hline $\begin{array}{l}\text { Dolostone } \\
\quad \text { (dolomite) }\end{array}$ & Shale & Limestone & Cobleskill Limestone \\
\hline Limestone & Shale & Dolostone (dolomite) & Cobleskill Limestone \\
\hline $\begin{array}{l}\text { Dolostone } \\
\quad \text { (dolomite) }\end{array}$ & Shale & Evaporite & Syracuse Formation \\
\hline \multicolumn{4}{|c|}{ Camillus } \\
\hline Shale & Dolostone (dolomite) & Evaporite; black shale & Camillus, Syracuse, and Vernon Formations \\
\hline Shale & Dolostone (dolomite) & Evaporite & Camillus and Syracuse Formations \\
\hline Shale & Black shale & - & Vernon Shale \\
\hline
\end{tabular}


Table 2. Reclassified bedrock geologic units for karst aquifers in New York.-Continued

[Geologic units are from Horton and others (2017). —, not designated]

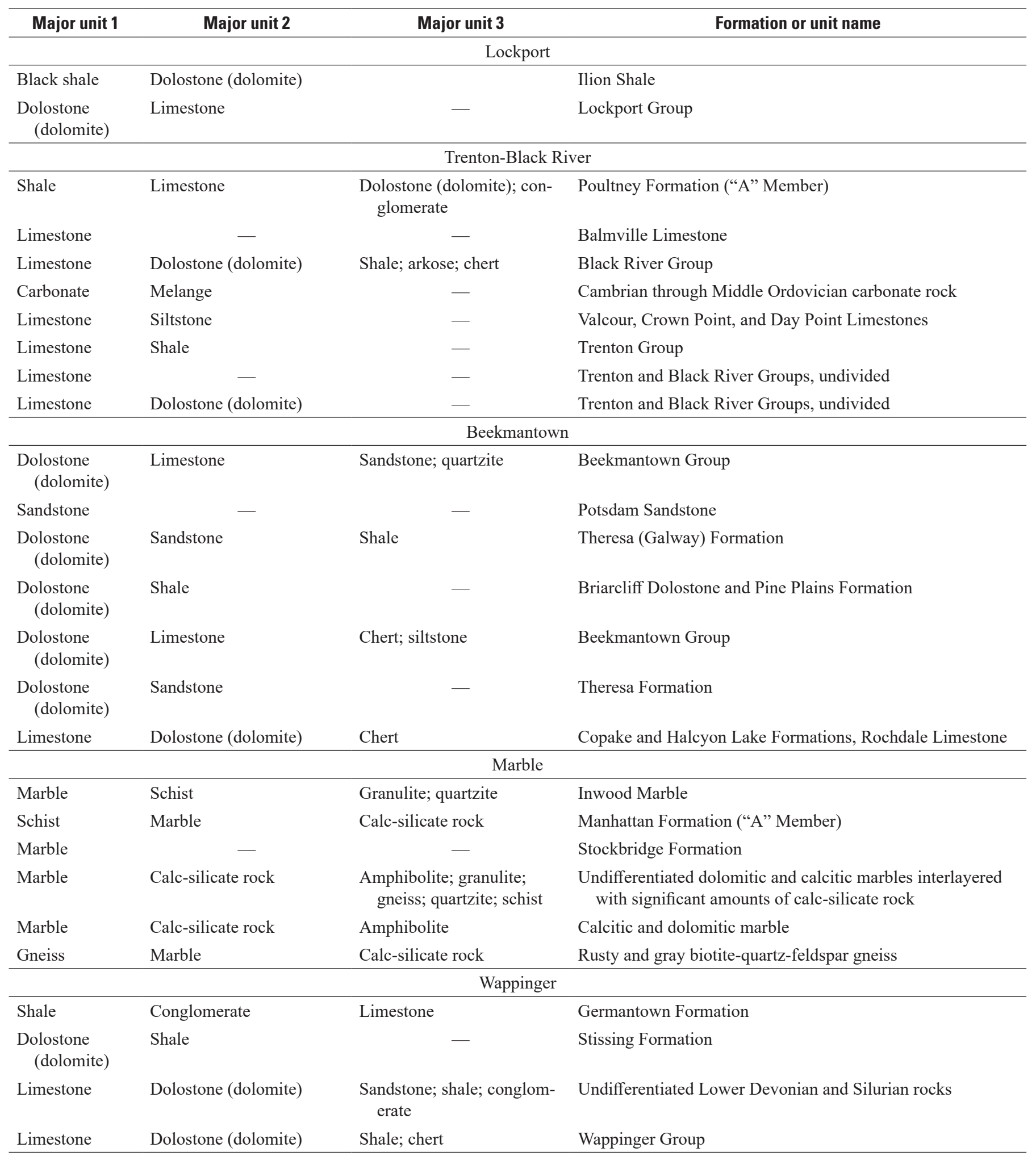




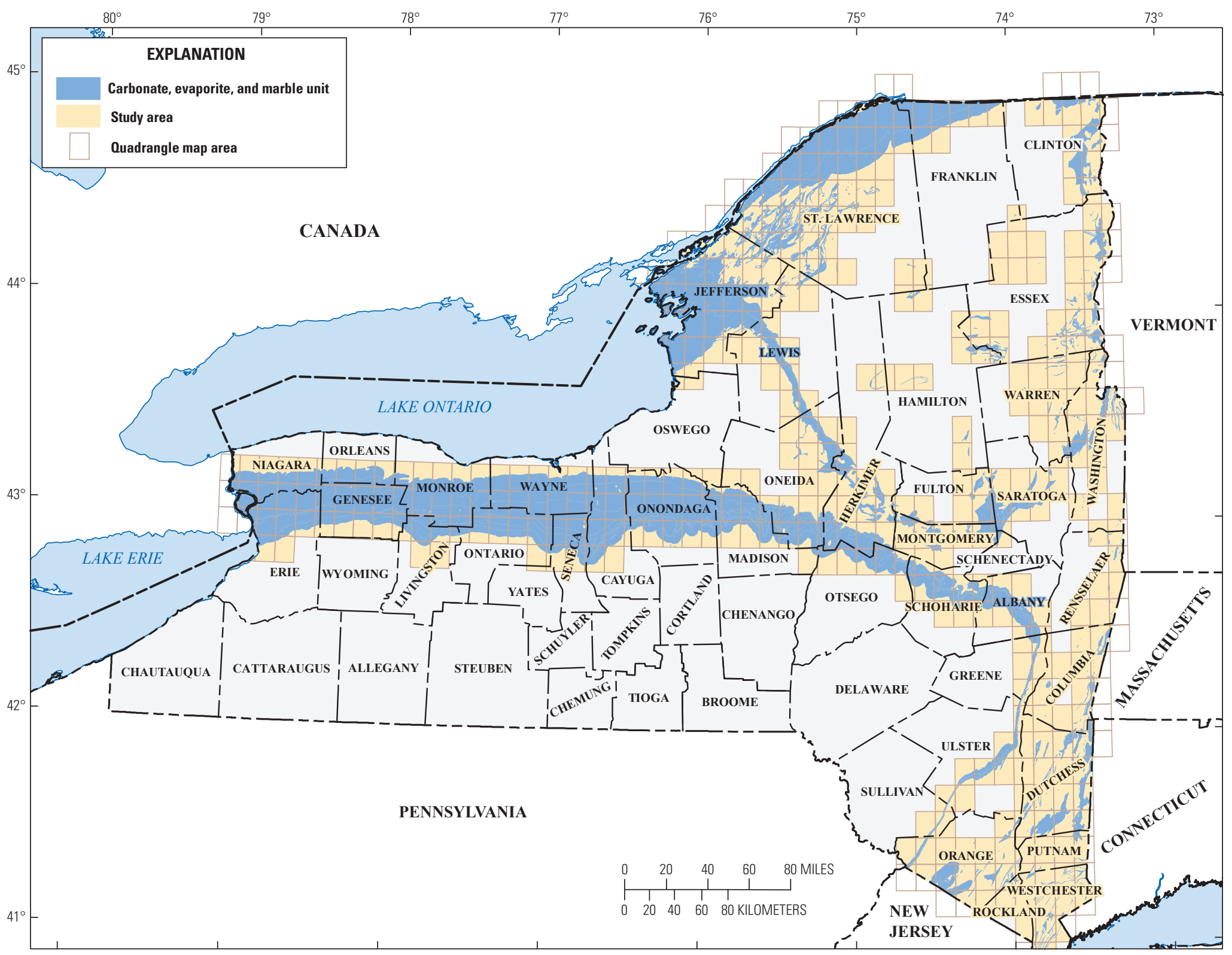

Figure 23. Study area boundary and selected U.S. Geological Survey 7.5-minute quadrangle maps adopted for geographic information system (GIS) analyses of karst aquifers in New York. Selected bedrock geologic units are shown. 
Table 3. Sources for data acquired to conduct geographic information system analyses for karst aquifers in New York.

[lidar, light detection and ranging; DEM, digital elevation model; gSSURGO, gridded Soil Survey Geographic database; NLCD 2011,2011 National Land Cover Database]

\begin{tabular}{lll}
\hline \multicolumn{1}{c}{ Data } & Data type & Source \\
\hline Digital contours & & Closed depression identification data \\
Digital raster graphic images & Vector & Tyler and Greenlee (2012) \\
Lidar-derived bare-earth DEMs & Raster & $1: 24,000$-scale, 7.5-minute topographic maps (U.S. Geological Survey, 2020) \\
\hline & & New York State Office of Information Technology Services (2017) \\
\hline Bedrock geology & \multicolumn{1}{c}{ Ancillary data } \\
Soils & Vector & Horton and others (2017) \\
Land cover & Raster & gSSURGO for New York (Natural Resources Conservation Service, 2014) \\
\hline
\end{tabular}

The digital contour database of closed depressions contains features derived from data associated with Tyler and Greenlee (2012). The source data are a statewide contour dataset that was generated from the National Elevation Dataset (U.S. Geological Survey, 2017a) and the National Hydrography Dataset (U.S. Geological Survey, 2017b) in a fully automated process. The process created digitally produced contours that match, as closely as possible, the cartographic contours that appear on the 1:24,000-scale, 7.5-minute USGS topographic maps. An exact match was not possible because the digitally produced contours are based on newer, more accurate horizontal and vertical datums than those used to create the contours appearing on the topographic maps
(Tyler and Greenlee, 2012). Furthermore, deletion of very small polygonal contours was a processing step used in the development of the digital contours (Tyler and Greenlee, 2012). Within the study area, the discrepancy between digitally produced closed depression contours and closed depression contours appearing on 7.5-minute topographic maps is substantial. The digital contour lines representing closed depressions were converted to polygons and added to the inventory (fig. 24).

The features included in the digital raster graphic database of closed depressions were compiled to address the discrepancy between digitally produced closed depression contours and closed depression contours appearing on
A

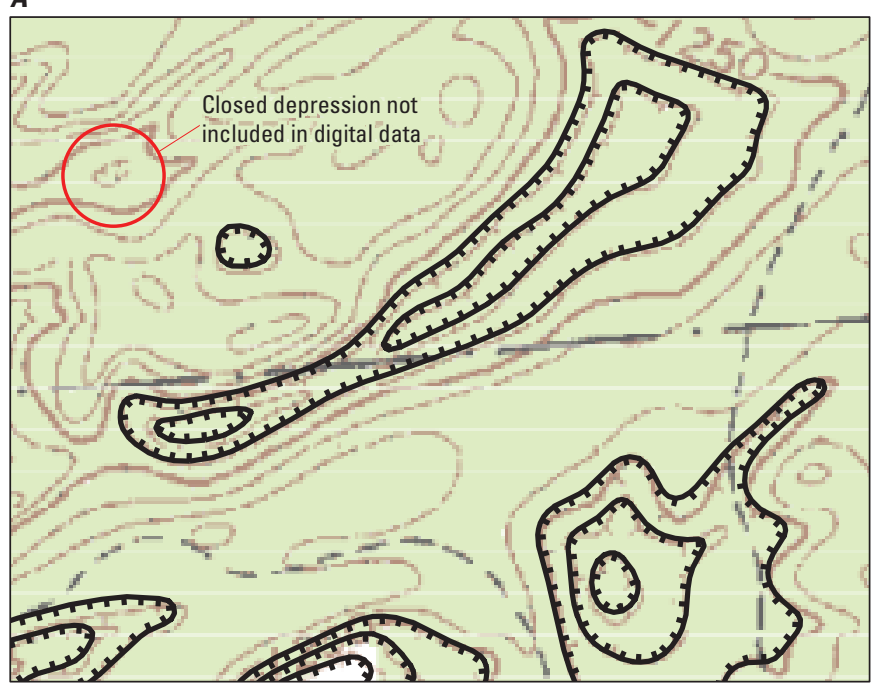

B

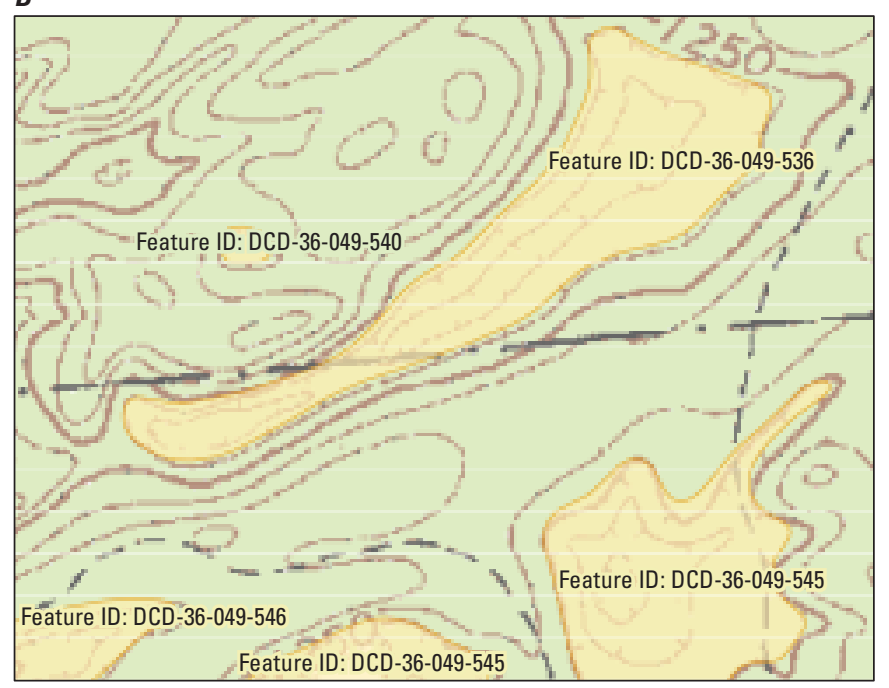

Figure 24. Closed depressions converted from line to polygon features. $A$, Closed depression contours appearing on the topographic map and in the digital contour dataset (black hachured lines; Tyler and Greenlee, 2012). An example of a closed depression that appears on the topographic map but is not included in the digital contour dataset (closed depression circled in red); $B$, closed depression contour lines from the digital contour dataset converted to polygons and assigned feature identification numbers for the digital contour database (Reddy and others, 2020). 
7.5-minute topographic maps. The features in the digital raster graphic database of closed depressions represent the locations of closed depressions that appear on the 7.5-minute topographic maps but were not represented in the digital contour dataset because of the previously described processing limitations. These closed depressions were digitized as feature centroids from an assemblage of approximately 650 digital raster graphic (DRG) images of scanned USGS 1:24,000-scale topographic maps. A georeferenced DRG was added as a background layer in a GIS. A dataset of disconnected stream reaches imported from the National Hydrography Dataset (U.S. Geological Survey, 2017b) for New York was used to assist with identification of closed depression features appearing on the DRG images (fig. 25).

The lidar database of closed depressions contains polygon features generated from analysis of 1- and 2-meter (m; 3.28- and 6.56-ft) horizontal resolution lidar-derived bareearth digital elevation models (DEMs; New York State Office of Information Technology Services, 2017). The DEMs were made from multiple collection projects conducted between 2005 and 2017. The vertical accuracy of the lidar projects ranged from a 4.0- to 18.5-centimeter ( $\mathrm{cm}$; 1.6- to 7.3-in.) root mean square error, and the horizontal accuracy of each project had less than 2-m root mean square error. At the time of analysis [2017], lidar data existed for approximately 85 percent of the study area (fig. 26). The DEMs were processed to identify closed depressions not represented in the digital contour database or the digital raster graphic database. The processes used followed the methods described by Doctor and Young (2013) using the ArcHydro Tools data modeling toolbox and by Wall and others (2015) using the Esri toolbox Hydrocutter.

$\boldsymbol{A}$

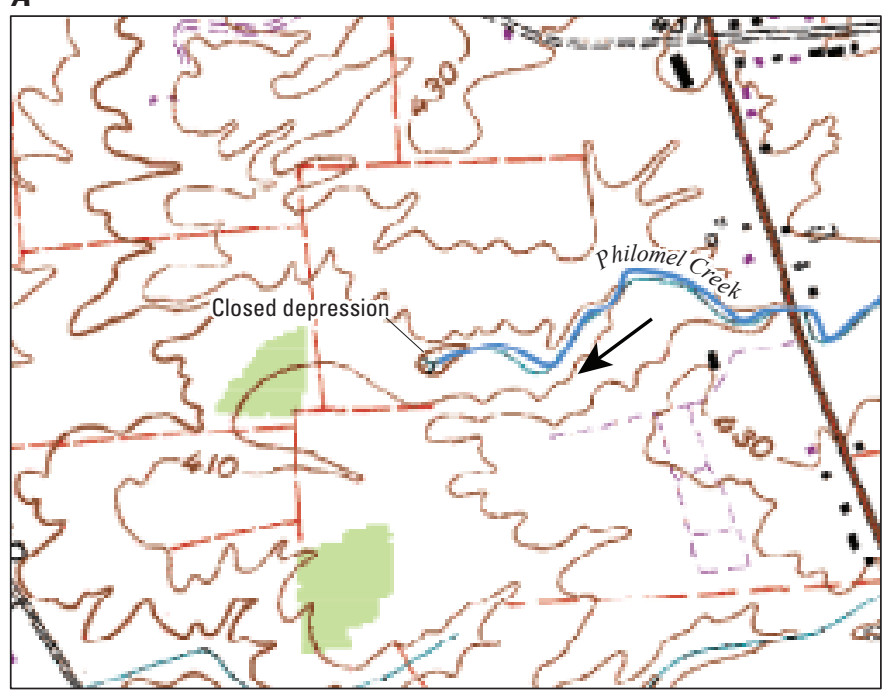

A lidar-derived bare-earth DEM was created for each 7.5-minute quadrangle map within the extent of the lidar coverage. Each DEM quadrangle was reconditioned using ArcGIS version 10.5.0 (Esri, 2016) to produce a polygon dataset of possible closed depressions. Reconditioning involved the removal of artificial dams along manmade features, such as streets and railroads, where surface water flows through drainage structures that are hidden to the DEM. Mapped inventories of culverts and bridges are not complete as these features are numerous, often undocumented, or on private land; therefore, it is necessary to develop a method to restore connectivity of flow paths. The hidden flow paths need to be added to the DEM, artificially lowering the DEM at locations of drainage structures, thereby extending flow paths through artificial dams and restoring connectivity of surface-water flow. To do so, methods developed by Doctor and Young (2013) and Wall and others (2015) were incorporated and combined.

Doctor and Young (2013) recondition DEMs by digitally creating flow paths through road and railroad embankments. The reconditioned DEM is run through the ArcGIS Fill tool (part of the Spatial Analyst tools) to identify cells that are lower than all its adjacent neighbors and raise the value of that cell to the lowest value of an adjacent cell. A depth raster is then generated by subtracting the reconditioned DEM from the filled DEM. Cells within the depth raster that satisfy a minimum depth threshold are extracted and converted to polygon features having area characteristics. A final closed depression dataset is then generated that satisfies both minimum depth and area thresholds.

Wall and others (2015) developed the Hydrocutter toolbox to aide in connecting streams through roads and railroad embankments. Two separate tools, Hydro and Cutter, are

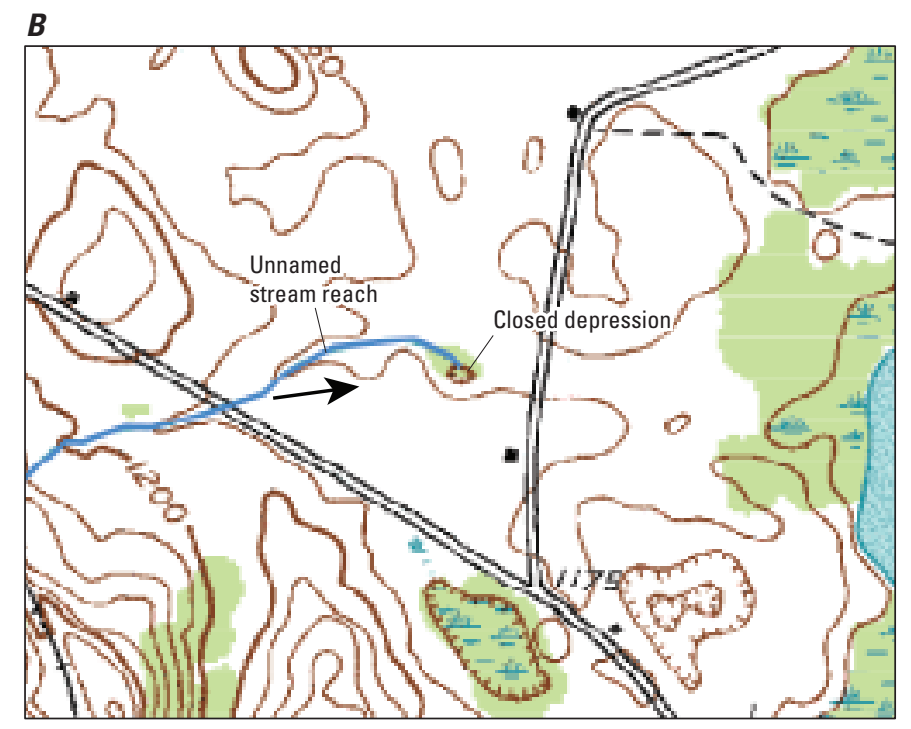

Figure 25. Closed depressions not represented in the digital contour data because of processing limitations that were added to the digital raster graphic database (Reddy and others, 2020) from analysis of digital raster graphic (DRG) images and disconnected stream reaches from the National Hydrography Dataset (NHD; U.S. Geological Survey, 2017b). A, Closed depression near Watertown, Jefferson County; $B$, Closed depression near Pine Woods, Madison County. 


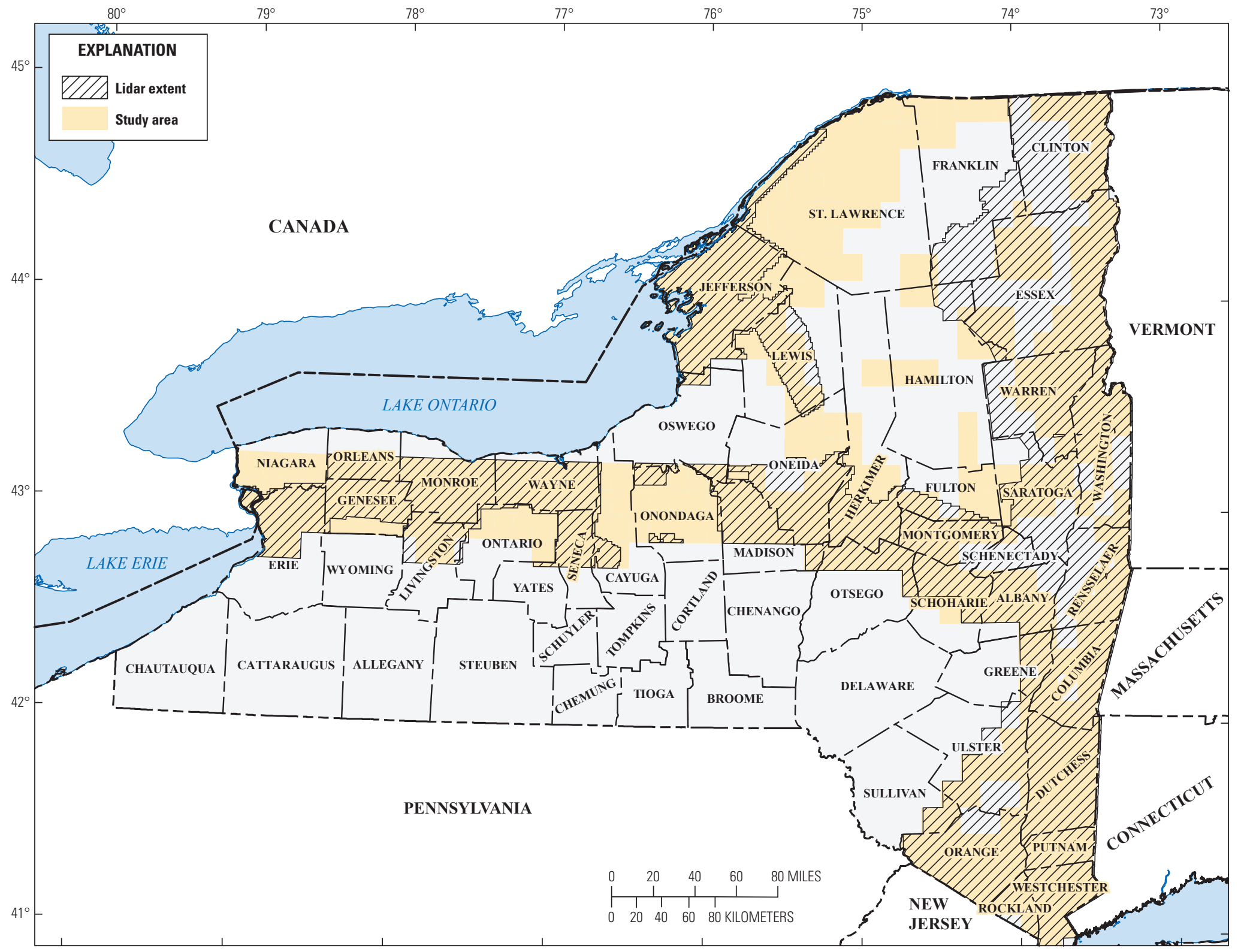

Figure 26. Extent of light detection and ranging (lidar)-derived digital elevation models within the karst aquifer study area in New York. 
included with the toolbox, which can be used iteratively to increase the precision of closed depression detections. Hydro allows flow measures to be manipulated and expose flow paths that do not exhibit a surficial, geomorphic expression such as a stream channel. Because of the scope of this study, Hydro was not used because flow paths from the National Hydrography Dataset (U.S. Geological Survey, 2017b) were created with adequate flow conditions to produce closed depressions of the desired scale. Cutter intersects and buffers roads and railroads with flow paths to generate a reconditioned raster DEM, which is then filled. A depth raster is generated by subtracting the reconditioned DEM from the filled DEM, and a final closed depression dataset is produced that satisfies both minimum depth and area thresholds. Results from the two methods were combined into one dataset.

The number of possible depressions identified per DEM quadrangle is determined by the minimum depth and area thresholds applied during data processing. Thresholds used for this statewide study were set at 1-m (3-ft) depth and 4,047-square meter ( $\mathrm{m}^{2} ; 1$-acre) area; these threshold values are greater than what is typically used for lidar-based sinkhole identification studies. For the purposes of this study, the use of lidar was primarily intended to identify closed depressions that were not represented in the digital raster graphic database, in the same manner that the DRG images were used to identify closed depressions not represented in the digital contour database. For that reason, the threshold values were based on random sampling of DRG-derived closed depressions within the study area and represent the approximate mean geometric characteristics of the closed depressions sampled. Figures 27 and 28 provide examples of lidar-derived anthropogenic and

$\boldsymbol{A}$

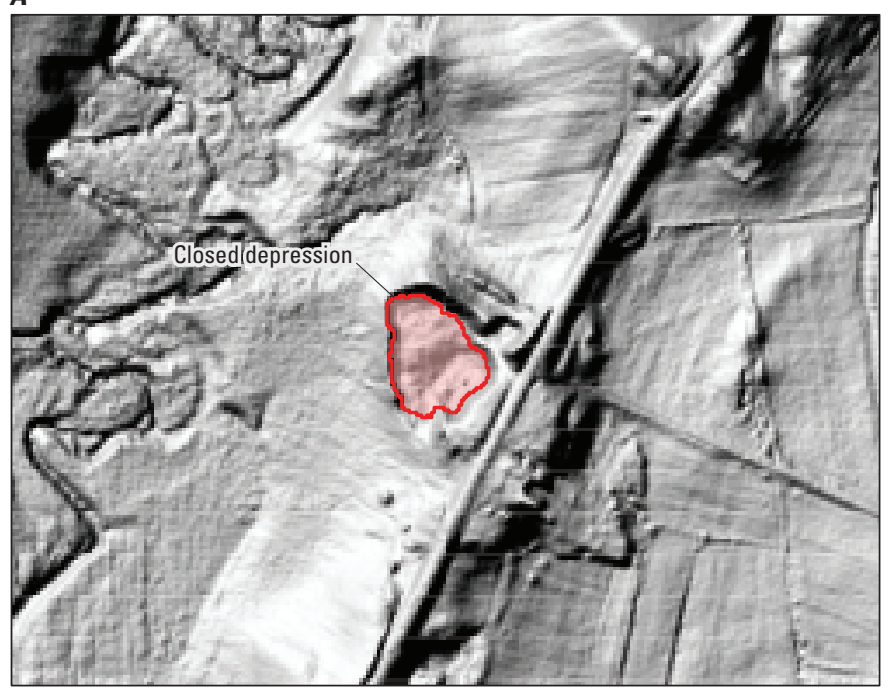

naturally formed closed depressions inventoried using these thresholds. For ongoing and planned large-scale, county-based assessments in New York, the thresholds will be reduced to 10 - and $30-\mathrm{cm}$ (3.9- and 11.8-in.) depth and $100-\mathrm{m}^{2}$ $(0.025$-acre) area.

Aerial imagery from Pictometry International (Pictometry International Corp., 2015) and Google Earth (Google, 2015) was used to photographically verify each lidar-derived closed depression. This process provided the opportunity to delete any remaining artificial depressions and to include a brief description of each feature. The lidar-derived features were grouped into a six-category classification scheme (table 4).

\section{Ancillary Data}

Multiple thematic datasets can be used to assess the probability that a closed depression contributes to focused recharge. For this study, the thematic data selected are bedrock type, soil type, soil infiltration rate, and land cover. For each closed depression that was inventoried, a series of overlay analyses were used to determine the predominant bedrock type, soil type, and infiltration rate within a $250-\mathrm{m}$ (820-ft) buffer around the feature. Land cover percentages within a 250-m (820-ft) buffer around each feature were also computed. The results from the overlay analyses for each closed depression are summarized in the "Results" section of this report; results are recorded as feature attributes to the data included in Reddy and others (2020).

The bedrock-type attribute was derived from the State Geologic Map Compilation Geodatabase of the Conterminous United States (Horton and others, 2017). Bedrock geologic

B

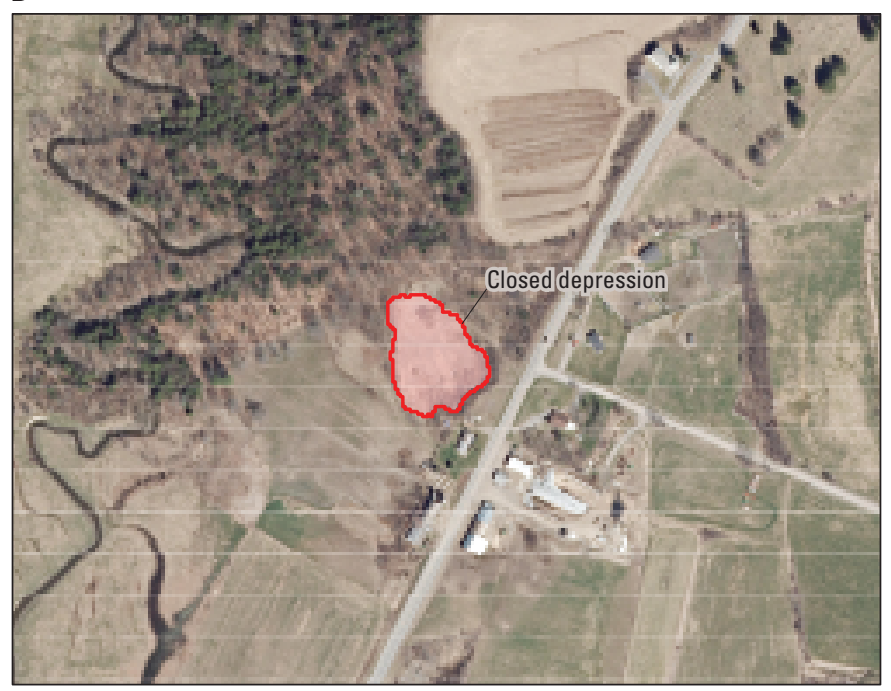

Figure 27. A closed depression near Argyle, Washington County, New York, identified using light detection and ranging (lidar)-derived digital elevation models (DEMs). This feature (inactive gravel pit) was not represented in other data sources; the feature as it appears on $A$, lidar-based hill-shade relief imagery and $B$, Google Earth imagery. The feature is divided between agricultural and developed land cover classes, underlain by noncarbonate bedrock (Canajoharie Shale) and glacial outwash soil with a high infiltration rate. 
A

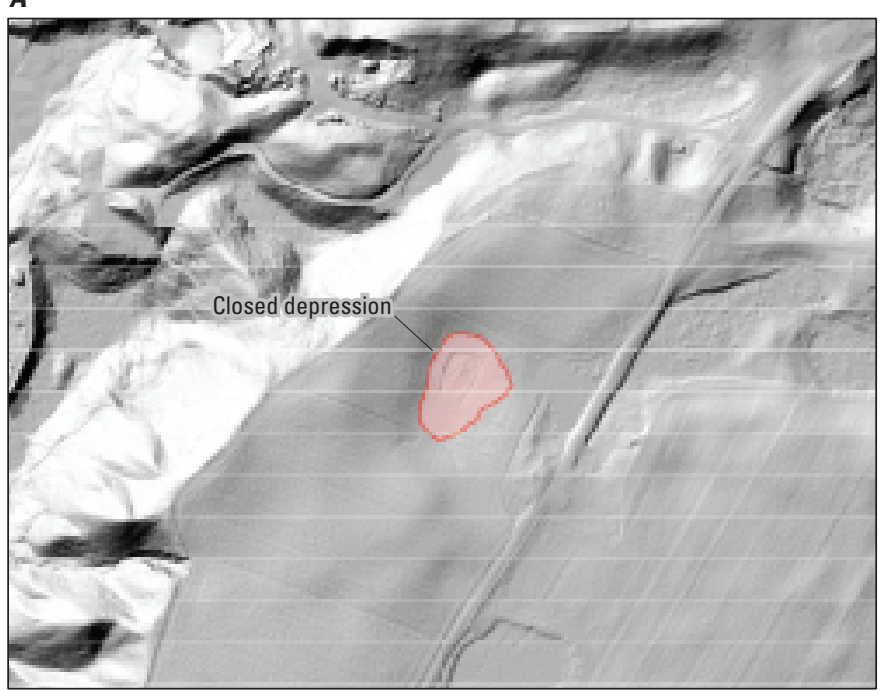

B

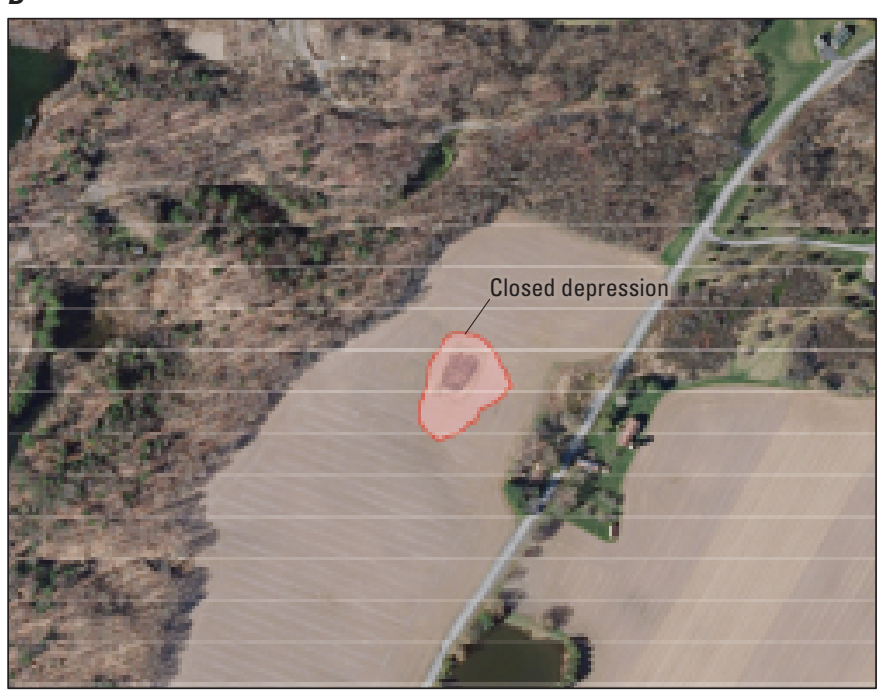

Figure 28. A closed depression near Ludlow Corners, Oneida County, New York, identified using light detection and ranging (lidar)-derived digital elevation models (DEMs); this feature was not represented in other data sources. The probable sinkhole as it appears on $A$, lidar-based hill-shade relief imagery and $B$, Google Earth imagery. The feature is located in an agricultural field, underlain by carbonate bedrock and glacial outwash soil with a high infiltration rate.

units were selected based on their established association with karst development; these units were then grouped into eight categories (table 2). A 2-mi-wide area of noncarbonate bedrock extending from Erie County to Greene County was included in the bedrock-type overlay analyses. In this area, which is south of the Onondaga and Helderberg Groups limestone, carbonate bedrock is overlain by shale. This represents an area of potential allogenic recharge. Surface water in this area flows from shale onto the adjacent carbonate bedrock and contributes to the potential for focused recharge (fig. 29).
Soil type was derived from the gridded Soil Survey Geographic database data for New York (Natural Resources Conservation Service, 2014). Based on research at Cornell University (Czymmek and others, 2004) and the U.S. Department of Agriculture (Stephen Page, Natural Resources Conservation Service, written commun., May 2017), 182 soil types in New York were identified as having characteristics that potentially present an increased risk for groundwater contamination. For this study, the 182 soil types were grouped into five classes (table 5). Three of the five soil classes

Table 4. Classification scheme for light detection and ranging (lidar)-derived closed depressions in New York.

[FeatCode, feature code]

\begin{tabular}{|c|c|c|}
\hline $\begin{array}{l}\text { Feat- } \\
\text { Code }\end{array}$ & Origin & Description \\
\hline 1 & Natural & $\begin{array}{l}\text { Definite closed depression, natural in origin, for example, a closed depression in agricultural land } \\
\text { exhibiting sinkhole signature. }\end{array}$ \\
\hline 2 & Anthropogenic & $\begin{array}{l}\text { Definite closed depression, anthropogenic in origin, for example, a small gravel pit or a surface } \\
\text { water detention basin. }\end{array}$ \\
\hline 3 & Natural and anthropogenic & $\begin{array}{l}\text { Probable closed depression, includes natural and anthropogenic in origin, for example, shallow } \\
\text { depression in agricultural land or probable detention basin at industrial park. }\end{array}$ \\
\hline 4 & Natural and anthropogenic & $\begin{array}{l}\text { Possible closed depression, includes natural and anthropogenic in origin, same as FeatCode } 3 \text { but } \\
\text { with less certainty. }\end{array}$ \\
\hline 5 & Anthropogenic & $\begin{array}{l}\text { Impeded areas where surface water drainage is impeded, resulting in standing liquid, not a true } \\
\text { closed depression, anthropogenic in origin, for example, surface water that collects along a } \\
\text { roadbed near a culvert. }\end{array}$ \\
\hline
\end{tabular}




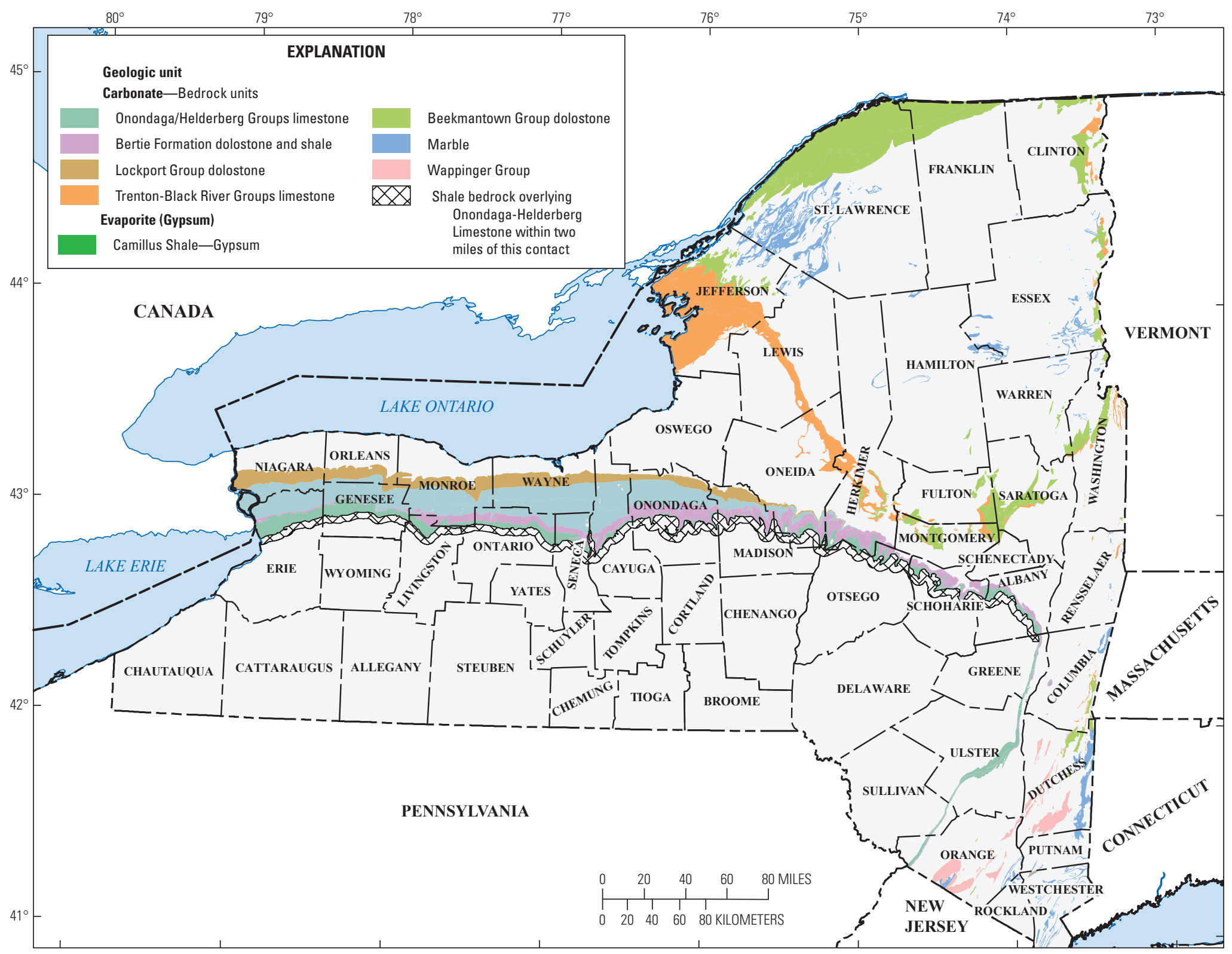

Figure 29. Shale bedrock in New York that may contribute allogenic recharge to the adjacent carbonate-rock aquifer. 
Table 5. Classification scheme for soils in New York.

[Soil classifications are from the Soil Survey Geographic database (SSURGO; Natural Resources Conservation Service, 2019). in., inch]

\section{SSURGO map unit name}

Soil class 1 , depth less than 20 in. over carbonate bedrock

Benson
Farmington
Galoo
Gouverneur
Hannawa
Joliet
Kings Falls
Rockland, limestone
Rubbleland (Genesee County)
Ruse
Summerville

Summerville

Soil class 2, depth less than 40 in. over carbonate bedrock

Aurora

Brockport

Camillus

Chaumont

Chippeny

Galway

Groton variant (Jefferson Co.)

Guff

Guffin

Lairdsville

Lockport

Madalin variant (Montgomery and Schenectady Co.)

Matoon

Neckrock

Nehasne

Newstead

Ogdensburg

Palatine

Riga

Sun variant (Monroe Co.)

Varick

Wassaic

Wilpoint

Soil class 3, depth range 20 to 60 in. over carbonate bedrock
Allis
Angola
Appleton, limestone substratum (Monroe, Orleans)
Cayuga, limestone substratum (Niagara)

Table 5. Classification scheme for soils in New York.-Continued

[Soil classifications are from the Soil Survey Geographic database (SSURGO; Natural Resources Conservation Service, 2019). in., inch]

\section{SSURGO map unit name}

Cazenovia, bedrock substratum (Monroe, Niagara, Orleans, Wayne)

Collamer, bedrock substratum (Jefferson, Seneca)

Gardenisle

Hilton, bedrock substratum (Livingston, Niagara, Orleans, Wayne)

Honeoye, limestone substratum (Monroe)

Kendaia, bedrock substratum (Orleans)

Lakemont, shale substratum (Orleans, Wayne)

Lima, limestone substratum (Monroe)

Lyons, rock substratum (Orleans)

Mohawk, shale substratum (Herkimer)

Niagara, bedrock substratum (Jefferson)

Nuhi

Ontario, bedrock substratum/moderately shallow (Cayuga, Niagara, Orleans, Seneca)

Ontario, stony (Genesee: OsB, OsC)

Ovid, bedrock substratum (Monroe, Niagara, Orleans)

Redwater

Stockbridge (Ulster)

Uwihreh

Yunenyeti Soil class 4, well-drained glacial outwash bedrock

Adams

Agawam

Allagash

Allard

Allard variant

Altmar

Alton

Atsion

$\mathrm{Au}$ Gres

Barbour

Berryland

Bonaparte

Carver

Castile

Champlain

Chenango

Colonie

Colosse

Colton

Constable

Copake 


\section{New York Karst Aquifers With an Inventory of Closed-Depression and Focused-Recharge Features}

Table 5. Classification scheme for soils in New York.-Continued

[Soil classifications are from the Soil Survey Geographic database (SSURGO; Natural Resources Conservation Service, 2019). in., inch]

\section{SSURGO map unit name}

Covert
Croghan
Deerfield
Deford
Deinache
Deposit
Duane
Duneland
Duxbury
Elnora
Enfield
Fahey

\section{Fluvaquents}

Fredon

Gougeville

Granby

Grattan

Groton

Halsey

Haven

Hempstead

Hinckley

Homer

Hoosic

Howard

Jebavy

Junius

Kars

Knickerbocker

Linlithgo

Middlebury

Mooers

Naumburg

Ninigret

Oakville

Occum

Occum variant

Olean

Ondawa

Otisville

Palmyra

Pawling
Table 5. Classification scheme for soils in New York.-Continued

[Soil classifications are from the Soil Survey Geographic database (SSURGO; Natural Resources Conservation Service, 2019). in., inch]

\begin{tabular}{|c|c|}
\hline & SSURGO map unit name \\
\hline Phelps & \\
\hline Philo & \\
\hline Pipestone & \\
\hline Pits, gravel & \\
\hline Plainfield & \\
\hline Plymouth & \\
\hline Podunk & \\
\hline Pompton & \\
\hline Pootatuck & \\
\hline Raypol & \\
\hline Rippowam & \\
\hline Riverhead & \\
\hline Rumney & \\
\hline Scarboro & \\
\hline Sciota & \\
\hline Searsport & \\
\hline Stafford & \\
\hline Sudbury & \\
\hline Suncook & \\
\hline Trestle & \\
\hline Trout River & \\
\hline Tunkhannoc & \\
\hline Udifluvents & \\
\hline Udipsamme & \\
\hline Waddington & \\
\hline Wainola & \\
\hline Wallace & \\
\hline Walpole & \\
\hline Wampsville & \\
\hline Wappinger & \\
\hline Wareham & \\
\hline Windsor & \\
\hline Wyalusing & \\
\hline Soil clas & th less than 20 in. over noncarbonate bedrock \\
\hline Abram & \\
\hline Arnot & \\
\hline Canaan & \\
\hline Couchsachr & \\
\hline Glover & \\
\hline Halcott & \\
\hline Hawksnest & \\
\hline Hogback & \\
\hline
\end{tabular}


Table 5. Classification scheme for soils in New York.—Continued

[Soil classifications are from the Soil Survey Geographic database (SSURGO; Natural Resources Conservation Service, 2019). in., inch]

\section{SSURGO map unit name}

\begin{tabular}{l} 
Hollis \\
Holyoke \\
Insula \\
Irona \\
Kearsarge \\
Knob Lock \\
Lordstown variant (Cortland Co.) \\
Lyman \\
Nassau \\
Quetico \\
Ricker \\
Rock Land \\
Rock Outcrop \\
Skylight \\
Taconic \\
Topknot \\
Tor \\
Torull \\
Tuller \\
Woodstock \\
Wotalf \\
\hline
\end{tabular}

represent thin soils over carbonate bedrock, one represents thin soils over noncarbonate bedrock, and the fifth represents soils over well-drained glacial materials.

Infiltration rate is an important soil characteristic to consider when assessing the probability that a closed depression contributes to focused recharge. A soil infiltration rate dataset was derived from the gridded Soil Survey Geographic database for New York (Natural Resources Conservation Service, 2014). The dataset identifies areas in New York with soils that have high and moderate infiltration rates (table 6).

The 2011 National Land Cover Database (NLCD; Homer and others, 2015) was used to compute land cover percentages within a $250-\mathrm{m}(820-\mathrm{ft})$ buffer around each closed depression. The NLCD 2011 data for New York is a 15-class land cover classification system. For this study, the NLCD 2011 data were reclassified to a five-class system (table 7). The land cover percentages were computed in ArcGIS using the Feature Statistics-To-Table tool available in the National WaterQuality Assessment Area-Characterization toolbox (Price and others, 2010)
Table 6. Classification scheme for soil infiltration rate in New York.

[gSSURGO, gridded Soil Survey Geographic database (Natural Resources Conservation Service, 2014); HydroGrp, hydrological group; >, greater than]

\begin{tabular}{lll}
\hline HydroGrp & $\begin{array}{c}\text { gSSURG0 soil } \\
\text { group }\end{array}$ & \multicolumn{1}{c}{ Description } \\
\hline 1 & Group A & $>1.42$ inches per hour \\
2 & Group B & 0.57 to 1.42 inches per hour \\
\hline
\end{tabular}

Table 7. Land cover classifications for New York.

[Classifications are from the National Land Cover Database for 2011 (Homer and others, 2015)]

\begin{tabular}{|c|c|}
\hline $\begin{array}{l}\text { Class } \\
\text { code }\end{array}$ & Classification \\
\hline \multicolumn{2}{|r|}{ Open water } \\
\hline 11 & Open water \\
\hline \multicolumn{2}{|r|}{ Developed } \\
\hline 21 & Developed, open space \\
\hline 22 & Developed, low intensity \\
\hline 23 & Developed, medium intensity \\
\hline 24 & Developed, high intensity \\
\hline 31 & Barren land \\
\hline \multicolumn{2}{|r|}{ Forested } \\
\hline 41 & Deciduous forest \\
\hline 42 & Evergreen forest \\
\hline 43 & Mixed forest \\
\hline 52 & Shrub/scrub \\
\hline \multicolumn{2}{|r|}{ Agriculture } \\
\hline 71 & Grassland/herbaceous \\
\hline 81 & Pasture/hay \\
\hline 82 & Cultivated crops \\
\hline \multicolumn{2}{|r|}{ Wetland } \\
\hline 90 & Woody wetlands \\
\hline 95 & Emergent herbaceous wetlands \\
\hline
\end{tabular}




\section{Results}

A total of 5,023 closed depressions were inventoried for this study (table 8). The digital contour database contains 2,032 closed depressions (fig. 30), the digital raster graphic database contains 2,477 closed depressions (fig. 31), and the lidar database contains 514 large closed depressions (fig. 32). Several areas of clustered closed depressions are evident when the findings from the three databases are combined (fig. 33). Some of the clusters occur in areas underlain by noncarbonate bedrock.

Table 8. Closed depressions in New York, by data source.

[lidar, light detection and ranging]

\begin{tabular}{llc}
\hline \multicolumn{1}{c}{ Data source } & Data type & $\begin{array}{c}\text { Number of } \\
\text { closed depres- } \\
\text { sions }\end{array}$ \\
\hline Digital contour database & Polygon & 2,032 \\
Digital raster graphic database & Point & 2,477 \\
Lidar database & Polygon & 514 \\
\hline
\end{tabular}

In terms of total number of closed depressions per county, Dutchess, Jefferson, and St. Lawrence rated highest with more than 300 in each county (fig. 34). In terms of concentration of closed depressions per unit study area for each county, Monroe, Ontario, and Oswego are rated highest with greater than 0.2 depression per square kilometer (fig. 35). Comparing the locations of the closed depressions with the selected bedrock geologic units indicated that 51 percent of the features inventoried lie outside the extent of the selected units (fig. 36); 10 percent of the closed depressions lie within the Beekmantown Group, and only 1 percent, within the Wappinger Group. The number of depressions within the remaining limestone, dolostone, and marble units ranges from 4 to 9 percent.

From the overlay analysis between closed depressions and soil class (fig. 37) it was determined that most of the closed depressions lie outside the extent of the five soil classes; 35 percent of the depressions lie within well-drained soils on sand-and-gravel deposits, which might include alluvium, alluvial fan, glaciofluvial, and glaciodeltaic deposits. The number of closed depressions within the remaining four soil classes ranges from 1 to 8 percent.

Twenty-three percent of the closed depressions are on soils with high infiltration rates (fig. 38), and 6 percent are on soils with moderate infiltration rates. Most of the closed depressions lie outside the extent of the high- to moderateinfiltration-rate soils.

Overlaying closed depressions and land cover indicated that half of the closed depressions inventoried lie within the forested land cover class (fig. 39), and 28 percent are in agricultural areas. The wetland land cover class accounts for 12 percent of the depressions; 9 percent are in areas classified as developed, and 1 percent of the closed depressions lie within the open water land cover class (these are typically small ponds or marshes). 


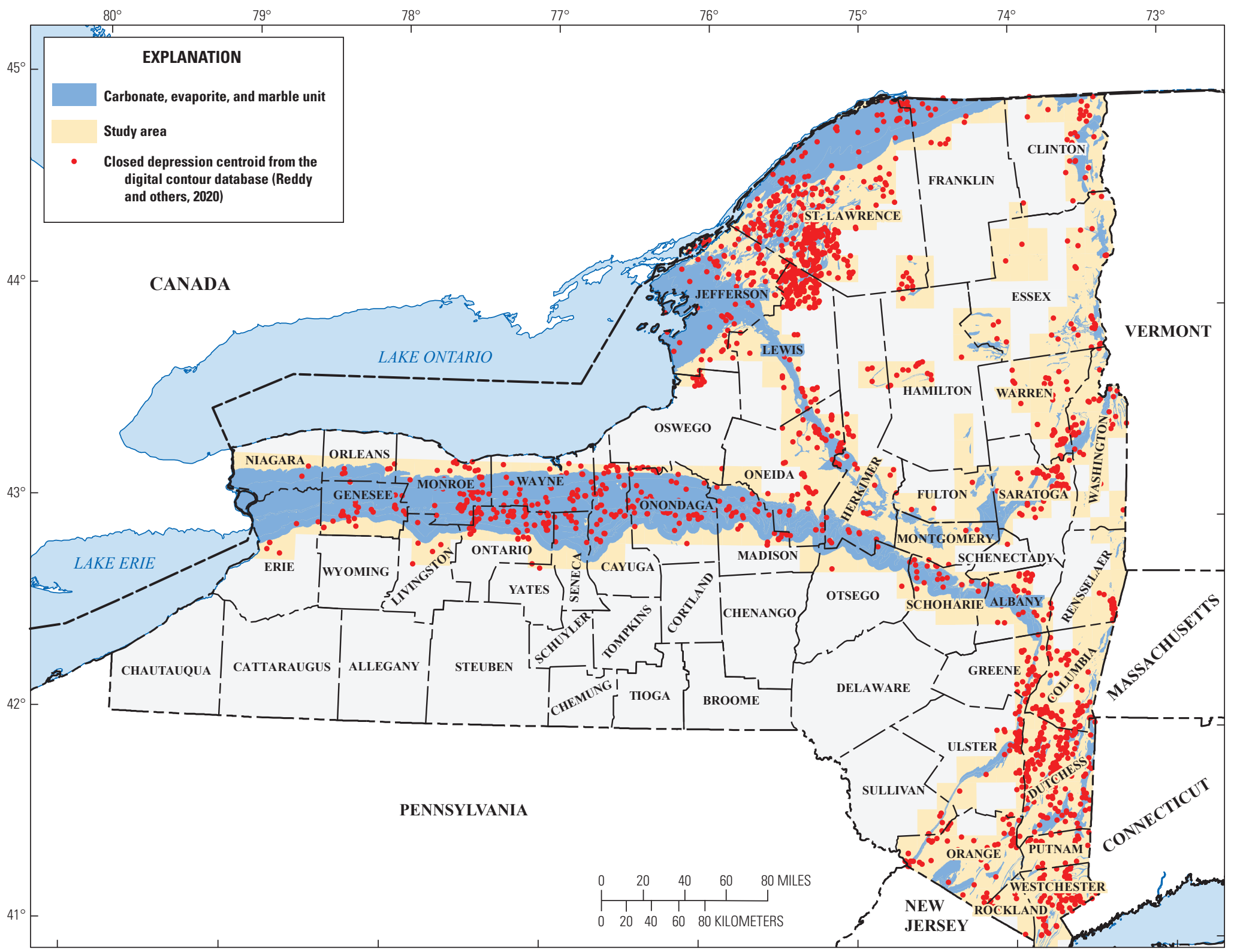

Figure 30. Distribution of closed depressions in New York in the digital contour database (Reddy and others, 2020). 


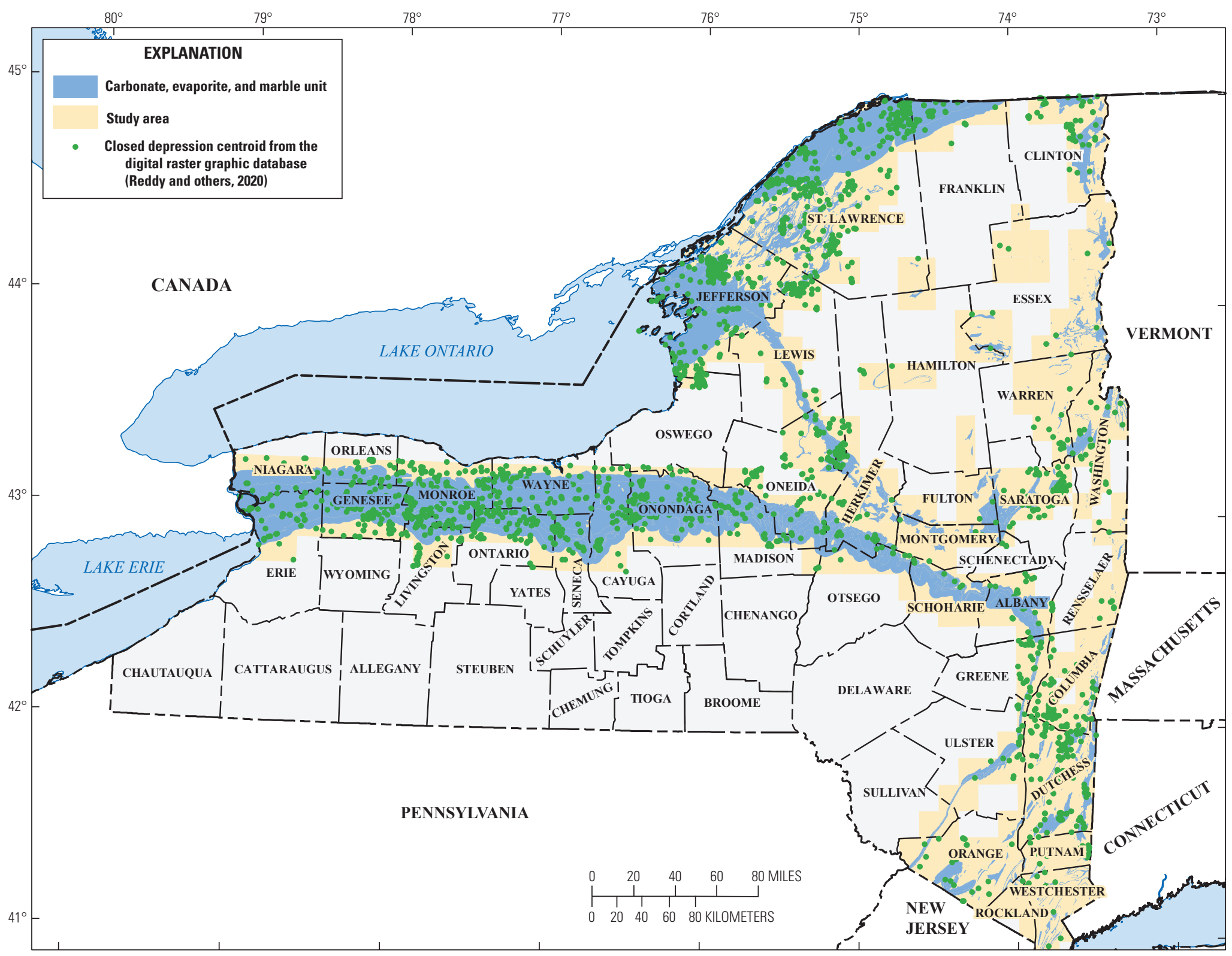

Figure 31. Distribution of closed depressions in New York in the digital raster graphic database (Reddy and others, 2020). 


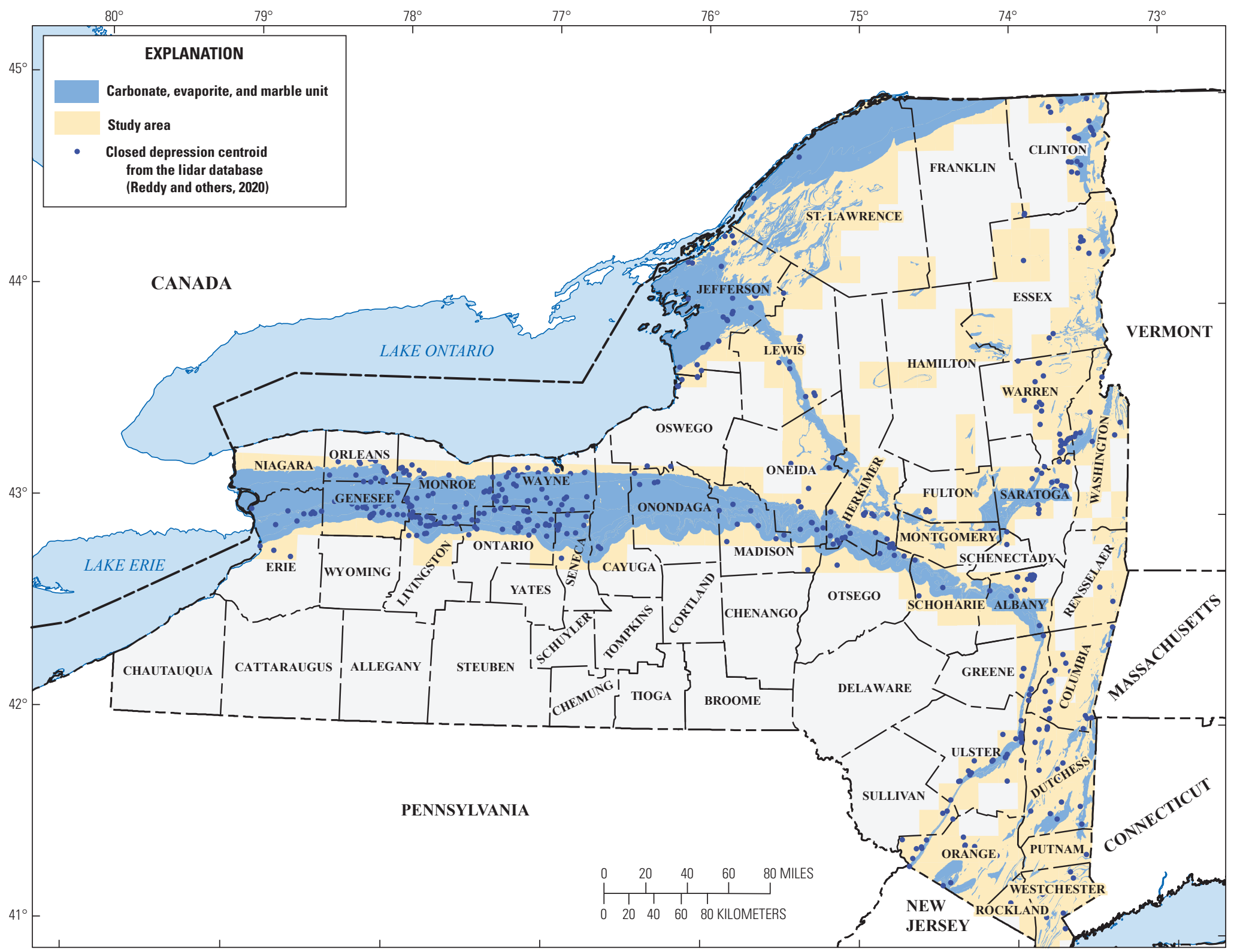

Figure 32. Distribution of closed depressions in New York in the light detection and ranging (lidar) database (Reddy and others, 2020). 


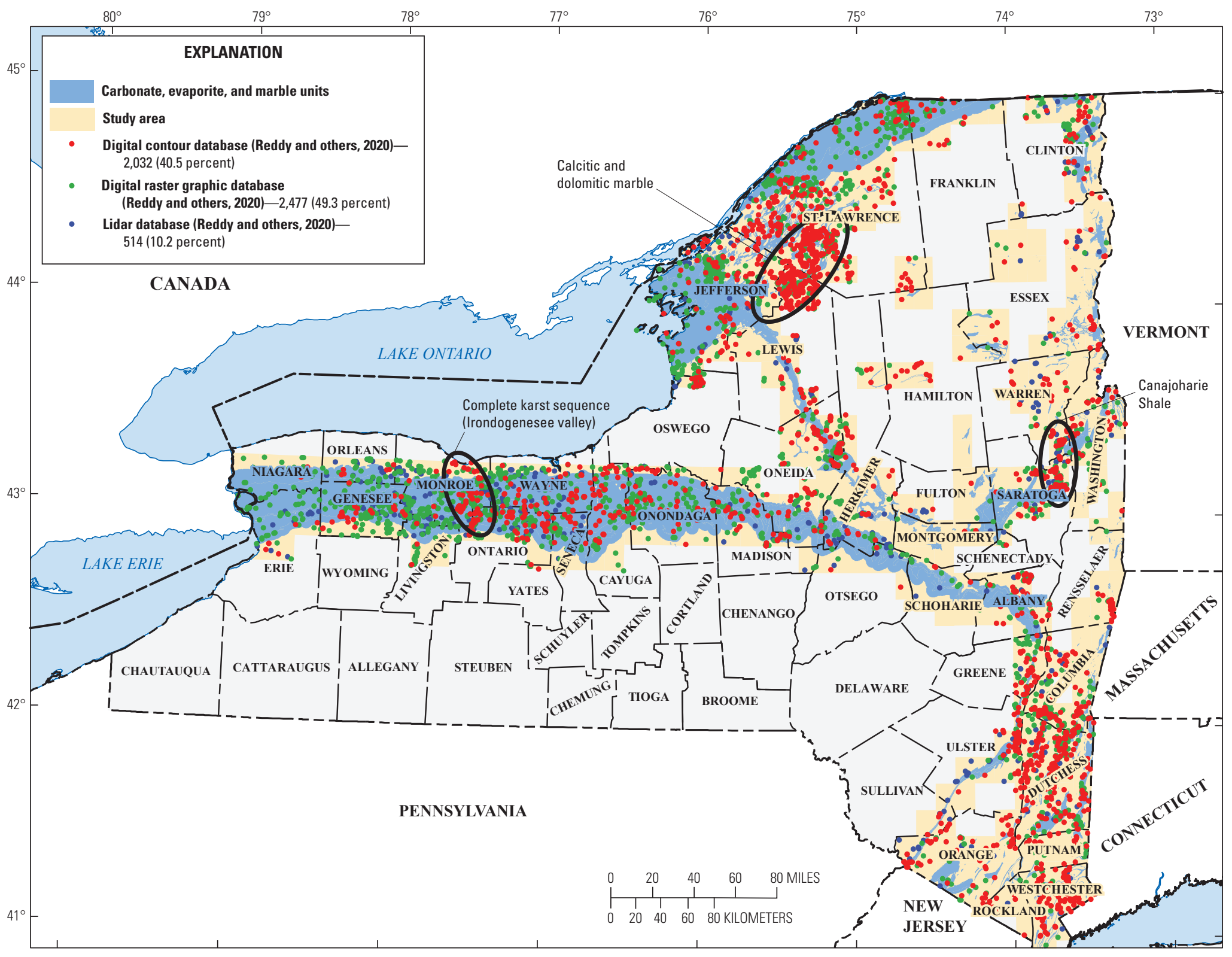

Figure 33. Distribution of all closed depressions in New York, from the digital contour, digital raster graphic, and light detection and ranging (lidar) databases (Reddy and others, 2020). 


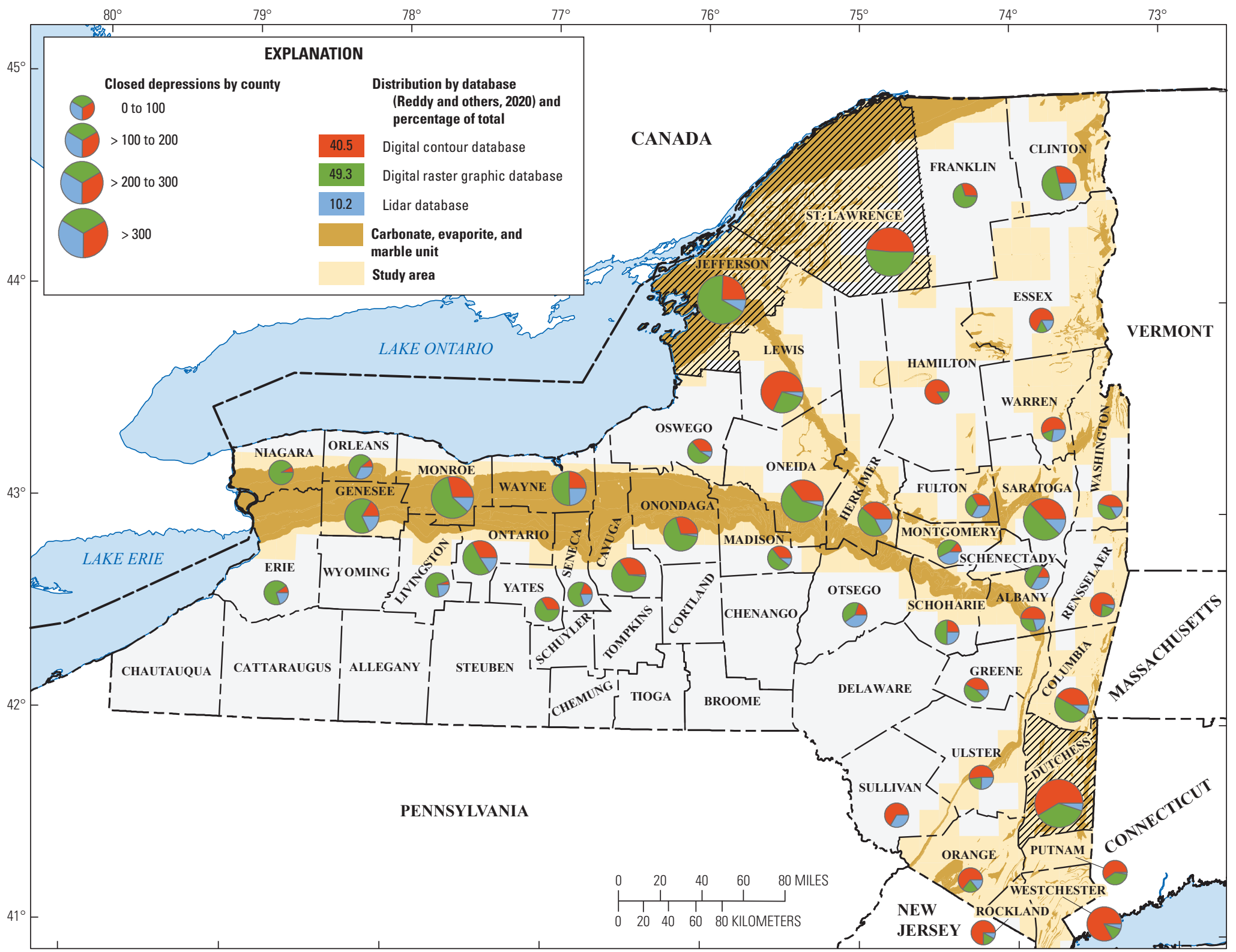

Figure 34. Concentration of closed depressions in New York, by source and quantity for each county. Dutchess, Jefferson, and St. Lawrence Counties (hachured) rate highest with more than 300 depressions in each county. >, greater than. 


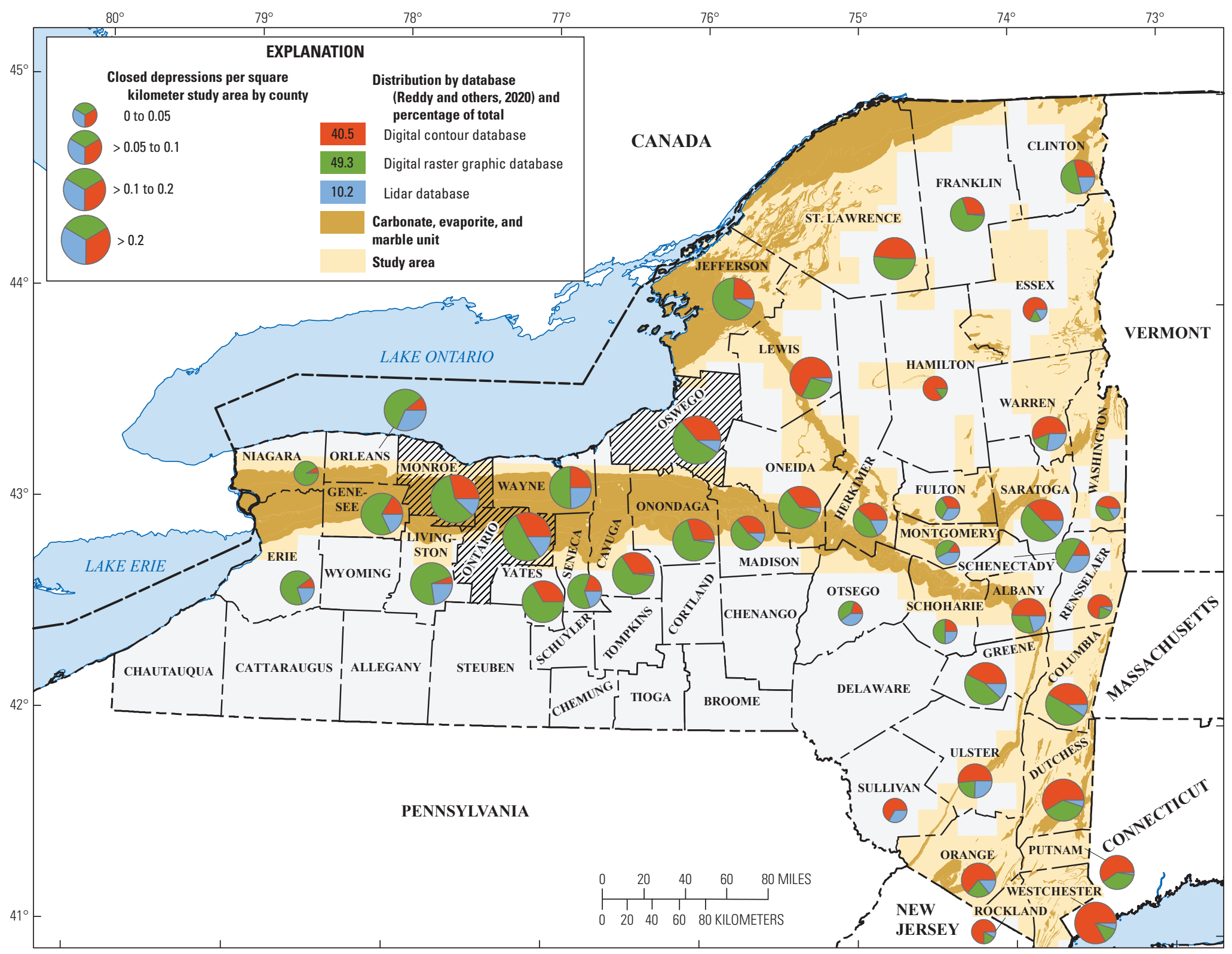

Figure 35. Concentration of closed depressions in New York, per square kilometer of study area for each county. The counties with the highest concentration of closed depressions (hachured) are Monroe, Ontario, and Oswego. >, greater than. 


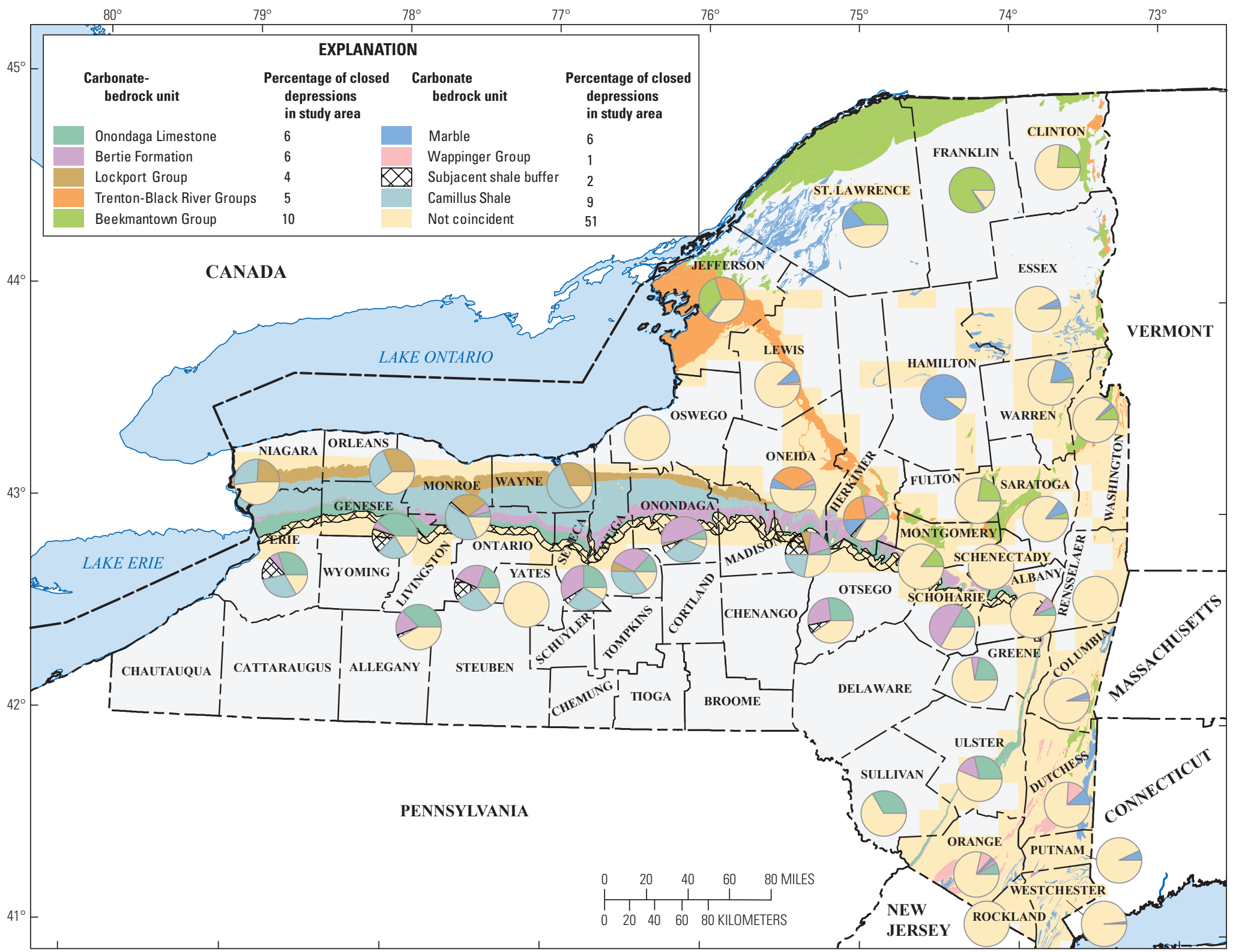

Figure 36. Bedrock geology and distribution of closed depressions in New York, by county. 


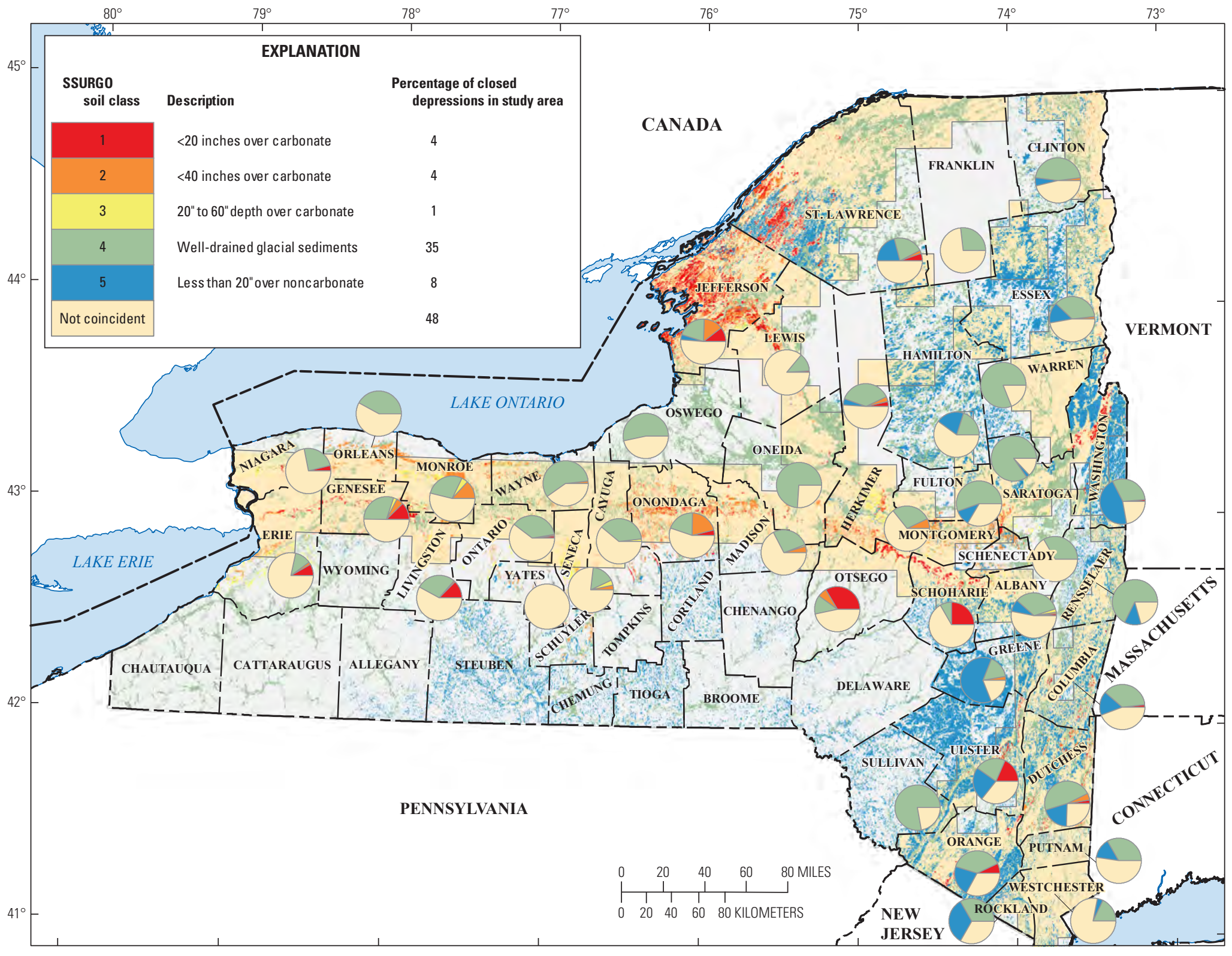

Figure 37. Distribution of soils and closed depressions in New York, by county. SSURGO, Soil Survey Geographic database (Natural Resources Conservation Service, 2019); $<$, less than. 


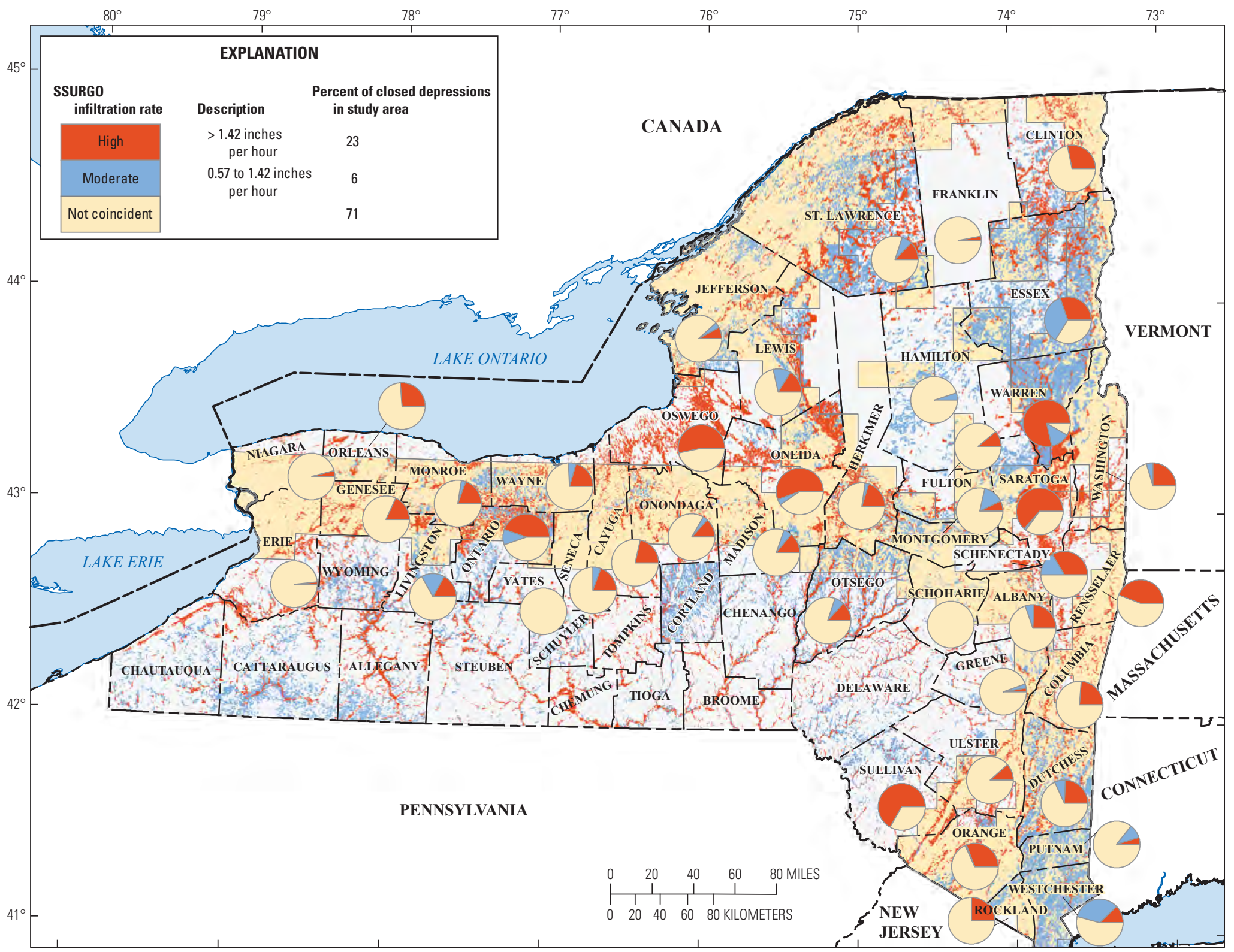

Figure 38. Distribution of soil infiltration rate and closed depressions in New York, by county. SSURG0, Soil Survey Geographic database (Natural Resources Conservation Service, 2019); >, greater than. 


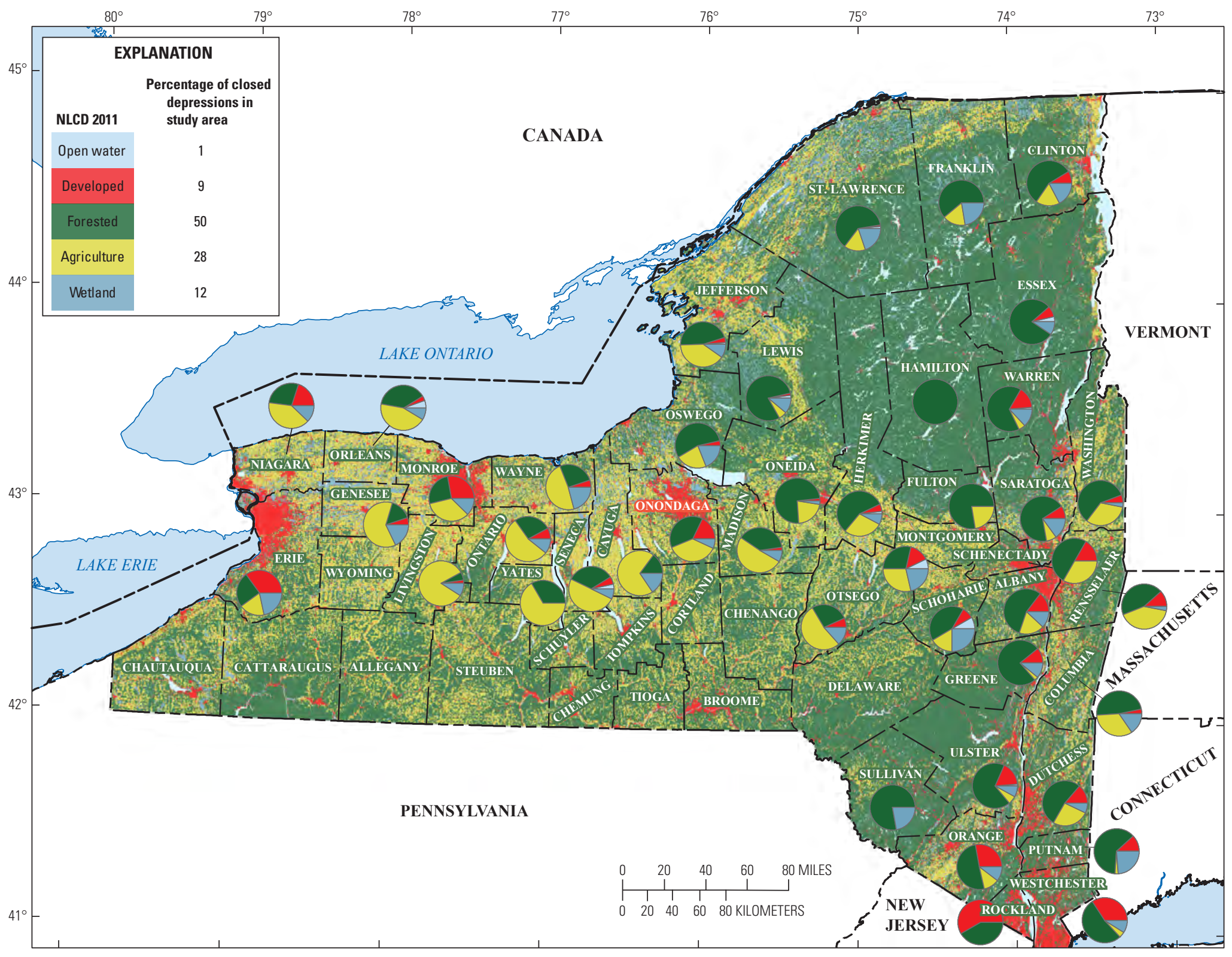

Figure 39. Distribution of land cover and closed depressions in New York, by county. NLCD 2011, National Land Cover Database for 2011 (Homer and others, 2015; U.S. Geological Survey, 2015). 


\section{Summary}

Karst is a landscape formed from the dissolution of soluble rock or rock containing minerals that are easily dissolved from within the rock. The landscape is characterized by sinkholes, caves, losing streams, springs, and underground drainage systems which rapidly move water through the karst. The two forms of karst in New York State include carbonate karst, which forms in carbonate rock (limestone, marble, and dolostone), and evaporite karst, which forms in rock that contains evaporite minerals (gypsum and halite). Closed depressions that are created at the land surface by karstification of the underlying bedrock or through other natural or anthropogenic processes focus surface-water recharge to underlying bedrock.

Past and recent studies of karst bedrock across the State have shown that areas of focused recharge in karstic carbonate rock allows contaminants to enter aquifer systems with little attenuation. Focused areas of recharge need to be identified to help prevent such contamination from sources on or adjacent to karst. The New York State Department of Environmental Conservation has begun to work with the agricultural community to make farmers and farm-planning advisors more aware of karst and how to manage their daily activities to reduce their impact on surface-water and groundwater resources, especially in karst areas. Where evaporite karst is present, in addition to limited attenuation of any contaminant within a karst system, there is also a greater potential for land-surface subsidence due to the more-aggressive dissolution of evaporite minerals (gypsum or halite) if close to the land surface or as a result of mining of these evaporite minerals.

The U.S. Geological Survey has compiled an inventory of closed depressions from statewide digital contour data, scanned 7.5-minute topographic maps known as a digital raster graphics, and light detection and ranging (lidar) digital elevation models. The identification of where karst rock is present in New York and the location of closed depressions over or near karst rock was completed using publicly available geospatial data and Esri ArcGIS software. Carbonate, evaporite, and marble geologic units were selected from a statewide 1:250,000-scale bedrock geology dataset. The selected geologic units were intersected with an index of 7.5-minute quadrangle maps. Quadrangle maps that overlay the selected geologic units form the basis of the study area.

Analysis of the data resulted in the identification of 5,023 closed depressions. The results are publicly available in three databases, one for each source of elevation data. The inventory was conducted such that there is no duplication of results from analysis of the three data sources. The closed depression features in the digital contour database and the lidar database are represented as polygon features. Points are used to represent the closed depressions in the digital raster graphic database.

A series of overlay analyses were conducted using the closed depressions and thematic data known to be key factors in determining the probability of a closed depression contributing to focused groundwater recharge. The thematic data layers used for the analyses were bedrock geology, soil type, soil infiltration rate, and land cover. Results from the overlay analyses were added as attributes to the data tables associated with the three publicly available databases.

Though the extent of karst development is important in understanding the surface water-groundwater interaction in karst terrains, some of the worst cases of groundwater contamination are in karst where only minor karst features might be present. The presence of karst, be it a short section of a solutioned fracture or an extensive cave system requires careful consideration, forward-looking environmental planning, and consistent water-quality protection to preserve New York State's water resources.

\section{References Cited}

Baker, V.R., 1976, Hydrogeology of a cavernous limestone terrain and the hydrochemical mechanisms of its formation, Mohawk River basin, New York: Empire State Geogram, v. 12 , no. 2 , p. $2-65$.

Bernstein, L.M., 1992, A revised lithostratigraphy of the Lower-Middle Ordovician Beekmantown Group, St. Lawrence Lowlands, Quebec and Ontario: Canadian Journal of Earth Sciences, v. 29, no. 12, p. 2677-2694, accessed February 2017 at https://doi.org/10.1139/e92-212.

Braun, B.B., 2000, Karst hydrology of the Cobleskill plateau, Schoharie County, New York: State University of New York at Oneonta, master's thesis, $76 \mathrm{p}$.

Cooper, M.P., and Mylroie, J.E., 2015, Glaciation and speleogenesis - Interpretations from the northeastern United States: New York, Springer International Publishing, 142 p. [Also available at https://doi.org/10.1007/978-3-31916534-9.]

Czymmek, K., van Es, H., and Geohring, L., 2004, Manure and groundwater-The case for protective measures and supporting guidelines. Cornell University, 10 p. [Also available at http://nmsp.cals.cornell.edu/publications/files/ Groundwater.pdf.]

Czymmek, K.J., Geohring, L., Lendrum, J., Wright, P., Albrecht, G., Brower, B., and Ketterings, Q.M., 2011, Manure management guidelines for limestone bedrock/karst areas of Genesee County, New YorkPractices for risk reduction: Cornell University Animal Science Publication Series 240, 9 p. [Also available at http://nmsp.cals.cornell.edu/publications/files/Karst_2_15 2011.pdf.] 
Dean, W.E., and Johnson, K.S., eds., 1989, v. 1794. Anhydrite deposits of the United States and characteristics of anhydrite important for storage of radioactive wastes, U.S. Geological Survey Bulletin, 134 p. [Also available at https://doi.org/ 10.3133/b1794.]

Doctor, D.H., and Young, J.A., 2013, An evaluation of automated GIS tools for delineating karst sinkholes and closed depressions from 1-meter lidar-derived digital elevation data, in Land, L., Doctor, D.H., and Stephenson, J.B., eds., Sinkholes and the engineering and environmental impacts of karst in Proceedings of the Thirteenth Multidisciplinary Conference on Sinkholes and the Engineering and Environmental Impacts of Karst, May 6-10, 2013, Carlsbad, New Mexico: Carlsbad, N. Mex., National Cave and Karst Institute, p. 449-458, accessed June 2019 at https://doi.org/10.5038/9780979542275.1156.

Eckhardt, D.A., Williams, J.H., and Anderson, J.A., 2011, Geophysical, stratigraphic, and flow-zone logs of selected wells in Cayuga County, New York, 2001-2011: U.S. Geological Survey Open-File Report 2011-1319, 13 p. [Also available at https://doi.org/10.3133/ofr20111319.]

Esri, 2016, ArcGIS release 10.5: Redlands, Calif., Esri software, accessed June 2019 at https://www.esri.com/software/ arcgis/eval-help/index.html.

Field, M.S., 2002, A lexicon of cave and karst terminology with special reference to environmental karst hydrology: U.S. Environmental Protection Agency EPA/600/R-02/003, 214 p. [Also available at https://cfpub.epa.gov/ncea/risk/ recordisplay.cfm?deid=54964.]

Fluhr, T.W., 1973, Construction problems, in Fluhr, T.W., and Terenzio, V.G., Geologic record of the work of the Board of Water Supply, City of New York: New York State Geological Survey Open File 06.046, p. 334-473.

Fluhr, T.W., and Terenzio, V.G., 1984, Engineering geology of the New York City water supply system: New York State Geological Survey Open File 05.08.001, 183 p.

Ford, D., and Williams, P., 2007, Karst hydrogeology and geomorphology: West Sussex, United Kingdom, John Wiley \& Sons, 562 p. [Also available at https://doi.org/10.1002/ 9781118684986.]

Forrest Environmental Services, Inc., 2001, Geophysical survey—Oatka Creek Park, Garbutt, New York: Monroe County Parks Department project FES00126, 18 p.

Fullerton, D.S., 1980, Preliminary correlation of post-Erie interstadial events $(16,000-10,000$ radiocarbon years before present), central and eastern Great Lakes region, and Hudson, Champlain, and St. Lawrence lowlands, United States and Canada: U.S. Geological Survey Professional Paper 1089, 52 p., 2 pls. [Also available at https://doi.org/ 10.3133/pp1089.]
Goodman, W.M., Gnage, D.J., and Smith, P.H., 2011, The saline water belt marginal to bedded salt deposits of the Silurian Salina Group, western New York State-A possible glacial "pocket" aquifer: Rochester Committee for Scientific Information Bulletin 333, 21 p. [Also available at http://www.server79x.net/rcsi_bulletins/Bulletin\%20333_ 2011.10.31.pdf.]

Google, 2015, Google Earth: Google, accessed 2015 at https://www.google.com/earth/.

Hackett, W.R., Gleason, G.C., and Kappel, W.M., 2009, Land-surface subsidence and open bedrock fractures in the Tully Valley, Onondaga County, New York: U.S. Geological Survey Open-File Report 1188, 16 p. [Also available at https://doi.org/10.3133/ofr20091188.]

Homer, C.G., Dewitz, J.A., Yang, L., Jin, S., Danielson, P., Xian, G., Coulston, J., Herold, N.D., Wickham, J.D., and Megown, K., 2015, Completion of the 2011 national land cover database for the conterminous United States-Representing a decade of land cover change information: Photogrammetric Engineering and Remote Sensing, v. 81, no. 5, p. 345-354. [Also available at

https://www.mrlc.gov/data/nlcd-2011-land-cover-conus-0.]

Horton, J.D., San Juan, C.A., and Stoeser, D.B., 2017, The state geologic map compilation (SGMC) geodatabase of the conterminous United States (ver. 1.1, August 2017): U.S. Geological Survey Data Series 1052, 46 p., apps. [Also available at https://doi.org/10.3133/ds1052.]

HydroTech Ground Water Consultants, 1989, Evaluation of previous reports concerning the Loch Lea residential development: Town of Clarence, New York, 5 p., supp.

Isachsen, Y.W., 1981, Contemporary doming of the Adirondack mountains-Further evidence from releveling: Tectonophysics, v. 71, nos. 1-4, p. 95-96. [Also available at https://doi.org/10.1016/0040-1951(81)90051-2.]

Johnson, K.S., 2003, Evaporite-karst problems in the United States, in Johnson, K.S., and Neal, I.T., eds., Evaporite karst and engineering/environmental problems in the United States-Oklahoma Geological Survey Circular 109 p. 1-20.

Johnson, K.S., 2007, Evaporite-karst problems and studies in the USA: Environmental Geology, International Journal of Geosciences, v. 53, no. 5, p. 937-943. [Also available at https://doi.org/10.1007/s00254-007-0716-8.]

Kappel, W.M., and Jennings, M.B., 2012, Water resources of the Iroquois National Wildlife Refuge, Genesee and Orleans Counties, New York, 2009-2010: U.S. Geological Survey Scientific Investigations Report 2012-5027, 53 p. [Also available at https://doi.org/10.3133/sir20125027.] 
Kresic, N., 2007, Hydraulic methods, in Goldscheider, N., and Drew, D., eds., Methods in karst hydrogeology: New York, Taylor and Francis Group, p. 65-92.

Lauritzen, S.E., and Mylroie, J.E., 2000, Results of speleotherm U/Th dating reconnaissance from the Helderberg Plateau, New York: Journal of Caves and Karst Studies, v. 62 , no. 1, p. $20-26$.

Marshak, S., 1990, Structural geology of Silurian and Devonian strata in the mid-Hudson Valley, New YorkFold-thrust belt tectonics in miniature: New York State Museum Map and Chart Series 51, 66 p.

Monroe, W.H., 1970, A glossary of karst terminology: U.S. Geological Survey Water Supply Paper 1899-K, 29 p. [Also available at https://doi.org/10.3133/wsp1899k.]

Natural Resources Conservation Service, 2014, Gridded soil survey geographic (gSSURGO) database for New York: U.S. Department of Agriculture database, accessed August 1, 2015, at https://gdg.sc.egov.usda.gov/.

Natural Resources Conservation Service, 2017, National soil survey handbook: U.S. Department of Agriculture Soil Survey, title 430, parts 600-659, [variously paged], accessed August 1, 2017, at https:/www.nrcs.usda.gov/wps/ portal/nrcs/detail/soils/ref/?cid=nrcs142p2_054242.

Natural Resources Conservation Service, 2019, Description of SSURGO database: U.S. Department of Agriculture website, accessed June 2019 at https://www.nrcs.usda.gov/wps/ portal/nrcs/detail/soils/survey/?cid=nrcs142p2_053627.

New York State Department of Environmental Conservation, 2017a, Downloadable mining database: New York State Department of Environmental Conservation database, accessed January 2017 at http://www.dec.ny.gov/lands/ 5374.html.

New York State Department of Environmental Conservation, 2017b, ECL SPDES general permit for concentrated animal feeding operations (CAFOs): New York State Department of Environmental Conservation permit GP-0-16-001, 52 p., accessed April 13, 2020, at https://www.dec.ny.gov/docs/ water_pdf/eclcafopermit(1).pdf.

New York State Department of Environmental Conservation, 2020, Aquifers in New York state: New York State Department of Environmental Conservation web page, accessed January 2020 at http://www.dec.ny.gov/lands/ 36119.html.

New York State Office of Information Technology Services, 2017, New York state high resolution DEM: New York State Office of Information Technology Services web page, accessed January 2017 at http://gis.ny.gov/elevation/NYSHigh-Res-DEM.htm.
Newland, D.H., 1929, The gypsum resources and gypsum industry of New York: New York State Museum Bulletin 28, $191 \mathrm{p}$.

Northern New York Genealogy, 2001, Caverns of Watertown: Northern New York Genealogy website, accessed 2017 at http://www.usgennet.org/usa/ny/town/watertown/caves.htm.

Olcott, P.G., 1995, Connecticut, Maine, Massachusetts, New Hampshire, New York, Rhode Island, Vermont, segment 12 of Ground water atlas of the United States: U.S. Geological Survey Hydrologic Atlas 730-M, 28 p., accessed November 2016 at https://doi.org/10.3133/ha730M.

Palmer, A.N., 1991, Origin and morphology of limestone caves: Geological Society of America Bulletin, v. 103, no. 1, p. 1-21. [Also available at https://doi.org/10.1130/ 0016-7606(1991)103<0001:OAMOLC>2.3.CO;2.]

Palmer, A.N., Rubin, P.A., and Palmer, M.V., 1991, Interaction between karst and glaciation in the Helderberg Plateau, Schoharie and Albany Counties, New York, in New York State Geological Association, 63d annual meeting, October 18-21, 1991, Oneonta, N.Y.: New York State Geological Association, field trip guidebook, p. 161-190.

Palmer, A.N., Rubin, P.A., Palmer, M.V., Engel, T.D., and Morgan, B., 2003, Karst of the Schoharie valley, New York, in New York State Geological Association, 75th annual meeting, September 12-14, 2003, Oneonta, N.Y.: New York State Geological Association field trip guidebook, p. 141-176.

Phillips, J.S., 1955, Origin and significance of subsidence structures in carbonate rocks overlying Silurian evaporites in Onondaga County, central New York: Syracuse University, master's thesis, $142 \mathrm{p}$.

Pictometry International Corp, 2015, Imagery and applications: Rochester, N.Y., Pictometry International Corp. website, accessed 2015 at https://www.eagleview.com/product/ pictometry-imagery.

Price, C.V., Nakagaki, N., and Hitt, K.J., 2010, National waterquality assessment (NAWQA) area-characterization toolbox: U.S. Geological Survey Open-File Report 2020-1268, accessed 2015 at https://doi.org/10.3133/ofr20101268.

Proett, B.A., 1978, Hydrology of Marcellus disappearing lake: Syracuse University, master's thesis, 118 p.

Reddy, J.E., and Kappel, W.M., 2010, Compilation of existing hydrogeologic and geospatial data for the assessment of focused recharge to the carbonate-rock aquifer in Genesee County, New York: U.S. Geological Survey Scientific Investigations Map 3132, 17 p., 20 sheets. [Also available at https://doi.org/10.3133/sim3132.] 
Reddy, J.E., Kappel, W.M., and Root, J.C., 2020, Data for statewide assessment of New York's karst aquifers with an inventory of closed-depression and focusedrecharge features: U.S. Geological Survey data release, https://doi.org/10.5066/P9HGN5IJ.

Robertson, S., 1970, Caves in Onondaga County, New York: The Northeastern Caver, v. 2, no. 4, p. 31-33.

Schmidt, C.F., 1953, History of the town of WheatlandScottsville, Mumford, Garbutt, Belcoda, Beulah, Wheatland Center: Rochester, N.Y., Carl F. Schmidt, 296 p. [Also available at https://catalog.hathitrust.org/Record/ 006106107.]

Schoharie Planning and Development Agency, 2002, Cobleskill small urban area corridor plan, June 2002-New York state routes 7, 10, 145; in the towns of Cobleskill, Richmondville, Seward, Sharon, and the villages of Cobleskill, Richmondville, Sharon Springs: Schoharie, New York, Schoharie Planning and Development Agency, 37 p. [Also available at https://www4.schohariecounty-ny.gov/ departments/comdev/corridor-plan/.]

Staubitz, W.W., and Miller, T.S., 1987, Geology and hydrology of the Onondaga aquifer in eastern Erie County, New York; with emphasis on ground-water-level declines since 1982: U.S. Geological Survey Water-Resources Investigations Report 86-4317, 50 p., 4 pls. [Also available at https://doi.org/10.3133/wri864317.]

Stumm, F., Chu, A., Como, M.L., and Noll, M.D., 2012, Preliminary analysis of the hydrologic effects of temporary shutdowns of the Rondout-West Branch water tunnel on the groundwater-flow system in Wawarsing, New York: U.S. Geological Society Scientific Investigation Report 2012-5015, 48 p. [Also available at https://doi.org/10.3133/ sir20125015.]

Tennissen, A.C., 1952, The distribution, occurrence, and origin of the gypsum in the Camillus Formation of the Syracuse East quadrangle, New York: Syracuse, Syracuse University, master's thesis, $77 \mathrm{p}$.

Town of Wheatland, 2015, §130-20. MS mine subsidence hazard district, in Article II. Zoning map; district regulations, in chap. 30. Zoning: Town of Wheatland [N.Y.] code, accessed April 13, 2020, at https://ecode360.com/print/WH0137? guid $=10501484$.

Tyler, D.J., and Greenlee, S.K., 2012, Creation of digital contours that approach the characteristics of cartographic contours: U.S. Geological Survey Scientific Investigations Report 2012-5167, 31 p., apps. [Also available at https://doi.org/10.3133/sir20125167.]
U.S. Environmental Protection Agency, 2012, Cayuga County groundwater contamination Superfund site, Cayuga County, New York: U.S. Environmental Protection Agency Superfund proposed plan, 19 p., accessed April 13, 2020, at https://semspub.epa.gov/work/02/123460.pdf.

U.S. Environmental Protection Agency, 2017, Lehigh valley railroad, Le Roy, New York: U.S. Environmental Protection Agency Superfund website, accessed April 13, 2020, at https://cumulis.epa.gov/supercpad/cursites/csitinfo.cfm? id $=0203481$.

U.S. Geological Survey, 1950, Le Roy quadrangle, New York, 7.5 minute series (topographic): U.S. Geological Survey topographic map, 1:24,000, accessed May 23, 2019, at https://ngmdb.usgs.gov/topoview/viewer/\#15/42.9804/ -77.8944 .

U.S. Geological Survey, 1966, Brantingham quadrangle, New York, Lewis Co., 7.5 minute series (topographic): U.S. Geological Survey topographic map, 1:24,000, accessed May 23, 2019, at https://catalog.data.gov/dataset/usgs-124000-scale-quadrangle-for-brantingham-ny-19661d129.

U.S. Geological Survey, 2013, National hydrography geodatabase: U.S. Geological Survey The National Map viewer, accessed 2017 at https://www.usgs.gov/core-sciencesystems/ngp/tnm-delivery/.

U.S. Geological Survey, 2014, MAPINDICES New York state or territory FileGDB 10.1: U.S. Geological Survey dataset, accessed 2016 at https://www.sciencebase.gov/catalog/item/ 53d7cd8ee4b06f0f87b7427b.

U.S. Geological Survey, 2015, USGS water data for the nation: U.S. Geological Survey National Water Information System database, accessed May 8, 2015, at https://doi.org/ 10.5066/F7P55KJN.

U.S. Geological Survey, 2017a, The national map: U.S. Geological Survey National Geospatial Program website, accessed 2017 at https://www.usgs.gov/core-sciencesystems/national-geospatial-program/national-map.

U.S. Geological Survey, 2017b, National hydrography dataset: U.S. Geological Survey National Hydrography web page, accessed 2017 at https://www.usgs.gov/core-sciencesystems/ngp/hydrography/national-hydrography-dataset.

U.S. Geological Survey, 2020, US Topo-Maps for America: U.S. Geological Survey web page, accessed April 2020 at https://www.usgs.gov/core-science-systems/nationalgeospatial-program/us-topo-maps-america.

van der Hoorne, K., 2010, The Marcellus disappearing lakeThe contribution of surface runoff to two flooding events in 2010: State University of New York at Brockport, master's thesis, $62 \mathrm{p}$. 
Veni, G., DuChene, H., Crawford, N.C., Groves, C.G., Huppert, G.N., Kastning, E.H., Olson, R., and Wheeler, B.J., 2001, Living with karst-A fragile foundation: American Geological Institute Environmental Awareness Series 4, 69 p. [Also available at http://www.agiweb.org/ environment/publications/karst.pdf.]

Wall, J., Doctor, D.H., and Terziotti, S., 2015, A semiautomated tool for reducing the creation of false closed depressions from a filled lidar-derived digital elevation model, in Land, L., Doctor, D.H., and Stephenson, J.B., eds., Proceedings of the 14th Multidisciplinary Conference on Sinkholes and the Engineering and Environmental Impacts of Karst, May 6-10, 2015, Carlsbad, N. Mex.: Carlsbad, N. Mex., National Cave and Karst Institute, p. 255-262, accessed 2019 at https://doi.org/https://doi.org/.

Waller, R.M., and Ayer, G.R., 1975, Water resources of the Black River basin, New York: New York State Department of Environmental Conservation Basin Planning Report BRB-1, 205 p. [Also available at https://archive.org/details/ usgswaterresourcesnewyork-brb_1.]

Weary, D.R., 2008, Preliminary map of potentially karstic carbonate rocks in the central and southern Appalachian states: U.S. Geological Survey Open-File Report 2008-1154, 1 pl. [Also available at https://doi.org/10.3133/ofr20081154.]
Weremeichik, J.M., and Mylroie, J.E., 2014, Glacial Lake Schoharie-An investigative study of glaciolacustrine lithofacies in caves, Helderberg plateau, central New York: Journal of Caves and Karst Studies, v. 76, no. 2, p. 127-138. [Also available at https://doi.org/10.4311/2013ES0117.]

Yager, R.M., and Kappel, W.M., 1987, Detection and characterization of fractures and their relation to groundwater movement in the Lockport dolomite, Niagara County, New York, in Khanbilvardi, R.M., and Philos, J., eds., Pollution, risk assessment, and remediation in groundwater systems: Washington, D.C., Scientific Publication Company, p. 149-195.

Yager, R.M., Miller, T.S., Kappel, W.M., Misut, P.E., Langevin, C.D., Parkhurst, D.L., and deVries, M.P., 2012, Simulated flow of groundwater and brine from a flooded salt mine in Livingston County, New York, and effects of remedial pumping on an overlying aquifer (ver. 1.1, August 23, 2012): U.S. Geological Survey Open-File Report 2011-1286, 16 p. [Also available at https://doi.org/ 10.3133/ofr20111286.] 



\section{Glossary of Selected Karst Terminology}

This glossary was adapted from Monroe (1970) and Field (2002). The referenced glossaries are more extensive, as the terms shown here are related to just those used in this report. The etymologic origin for some of the terminology is shown in brackets.

\section{A}

allogenic recharge Recharge from adjacent insoluble bedrock into a soluble karst aquifer.

aquifer A groundwater reservoir; pervious rock that is completely saturated and will yield water to a well or spring.

\section{B}

bare karst See naked karst

bedding plane A plane or surface that separates two strata of differing characteristics.

bicarbonate A salt containing the radical bicarbonate $\left(\mathrm{HCO}_{3}{ }^{-1}\right)$, such as calcium bicarbonate $\left[\mathrm{Ca}\left(\mathrm{HCO}_{3}\right)_{2}\right]$.

blowing cave $A$ cave out of which or into which a current of air flows intermittently.

\section{C}

calcite A mineral composed of calcium carbonate $\left(\mathrm{CaCO}_{3}\right)$, such as aragonite, but differing in crystal form; the principal constituent of limestone.

carbonate A salt or ester of carbonic acid; a compound containing the radical carbonate $\left(\mathrm{CO}_{3}-2\right)$, such as $\mathrm{CaCO}_{3}$. Also, a rock consisting mainly of carbonate minerals, such as limestone or dolostone.

cave A natural underground room or series of rooms and passages large enough to be entered by a person; generally formed by solution of limestone. Also, a similar artificial opening.

cave system An underground network of passages, chambers, or other cavities. Also, the caves in a given area related to each other hydrologically, whether continuous or discontinuous from a single opening.

chert Light-cream or gray to black rock composed of silica (silicon dioxide $\left[\mathrm{SiO}_{2}\right]$ ), found occurring as nodules or layers in limestone, or as a replacement of limestone.

clint [country of origin, United Kingdom] Slabs of limestone, parallel to the bedding, forming a fractured limestone pavement. Widened joints, or grikes, isolate individual limestone slabs.

closed depression A general term for any enclosed topographic basin having no external drainage, regardless of origin or size. conduit A subterranean stream course filled completely with water and always under hydrostatic pressure.

\section{D}

doline A basin- or funnel-shaped hollow in limestone, ranging in diameter from a few meters to a kilometer, and in depth from a few to several hundred meters. Some dolines are gentle grassy hollows; others are rocky cliff-bounded basins. Closed depressions receiving a stream are known as swallow holes or stream sinks. In the United States most dolines are referred to as sinks or sinkholes.

dolomite A mineral composed of calcium magnesium carbonate $\left[\mathrm{CaMg}\left(\mathrm{CO}_{3}\right)_{2}\right]$.

dolostone Rock chiefly composed of the mineral dolomite.

dolomitization The process whereby limestone becomes dolomite by the substitution of magnesium carbonate for part of the original calcium carbonate.

\section{E}

epiphreatic zone The zone in a cave system, immediately above the phreatic (saturated) zone, affected morphologically and hydrologically by floods too large for the cave to absorb at once. Also known as epiphreas.

exsurgence The point at which an underground stream reaches the surface if the stream has no known surface headwaters.

\section{$\mathbf{F}$}

fluorescein A reddish-yellow crystalline compound that imparts a brilliant green fluorescent color to water in very dilute solutions; used to label groundwater for identification of an emergence.

formation The fundamental unit in rock, a stratigraphic classification, consisting of a distinctive mappable body of rock.

G

grike [country of origin, United Kingdom] A vertical or subvertical cleft in a limestone pavement developed by solution along a joint or system of crisscrossing joints. Grikes separate clints from one another.

groundwater The part of the subsurface water that is in the zone of saturation. Used loosely by some to refer to any water beneath the surface. See also phreatic water.

gypsum A mineral composed of hydrous calcium sulfate $\left(\mathrm{CaSO}_{4} \cdot 2 \mathrm{H}_{2} \mathrm{O}\right)$.

H

hydraulic conductivity The ability of a rock unit to conduct water under specified conditions. 
inflow cave Cave into which a stream flows or formerly entered.

influent cave See inflow cave

intake or recharge area The surface area in which water is absorbed into an aquifer eventually to reach the zone of saturation.

\section{K}

karren [country of origin, Germany] Channels or furrows caused by solution on massive bare limestone surfaces; they vary in depth from a few millimeters to more than 1 meter and are separated by ridges. In modern usage, the terms are general, describing the total complex of superficial solution forms (grikes and clints) found on compact pure limestone.

karst [originally, the German form of the Slavic word kras or krs, meaning a bleak waterless place; the German name for a district east of Trieste having such terrain] A terrain, generally underlain by limestone, in which the topography is chiefly formed by the dissolving of rock, and which is commonly characterized by karren, closed depressions, subterranean drainage, and caves.

karst plain A plain on which closed depressions, subterranean drainage, and other karst features may be developed. Also called a karst plateau.

karst topography Topography dominated by features of solutional origin.

karstic 0ccasionally used as the adjective form of karst.

karstification Action by water, mainly chemical but also mechanical, that produces features of a karst topography, including such surface features as dolines, karren, and mogotes and such subsurface features as caves and shafts.

\section{L}

limestone A sedimentary rock consisting chiefly of calcium carbonate.

limestone pavement A bare plane surface of limestone, parallel to the bedding, commonly divided into blocks (clints, flachkarren) by solutionally widened joints (grikes, kluftkarren), and pitted by solution pans.

\section{M}

marble Limestone recrystallized and hardened by heat and pressure. Commercially, any limestone that will take a high polish

marl Unconsolidated sedimentary rock consisting largely of calcium carbonate and clay; usage varies from calcareous clay to earthy limestone; in some parts of the United States, the term has been used for any unconsolidated sedimentary rock containing fossil shells.
N

naked karst Karst topography having much exposed bedrock.

$\mathbf{P}$

paleokarst A karstified rock or area that has been buried by later sediments; in some places, ancient caves have been completely filled by the later sediments.

passage In a cave, the opening between rooms or chambers.

permeability The ability of a rock or soil to permit water or other fluids to pass through it.

phreatic water [from the Greek word $\varphi \rho \varepsilon \alpha_{\alpha} \rho$, meaning well] Water in the zone of saturation, below the water table.

phreatic zone The region below the water table, in which rock is saturated with water.

piezometric surface The imaginary surface to which water from a given aquifer will rise under its full static head. Also called potentiometric surface.

pipe Small cylindrical hole in unconsolidated sediments caused by removal of fine material by water.

piping Formation of a passage by water under pressure in the form of conduits through permeable materials, when the hydraulic head exceeds a certain critical value.

polje [Slavic word meaning field] In areas of karst topography, a very large closed depression, in some places several kilometers long and wide, having a flat floor either of bare limestone or covered by alluvium, and surrounded by generally steep walls of limestone.

ponor [Slavic] Hole in the bottom or side of a closed depression through which water passes to or from an underground channel. Compare to swallet, swallow hole.

porosity The ratio of the aggregate volume of interstices in a rock or soil to its total volume; generally stated as a percentage.

pseudokarst Karstlike terrain produced by a process other than the dissolving of rock, such as the rough surface above a lava field, where the ceilings of lava tubes have collapsed. Features of pseudokarst include lava tunnels, lava tubes, lava stalactites, and lava stalagmites.

R

recharge area See intake area

resurgence A point at which an underground stream reaches the surface and becomes a surface stream. In European literature, the term is reserved for the reemergence of a stream that has earlier sunk upstream; the term resurgence is applied to a stream without known surface headwaters. 
rhodamine A family of related chemical compounds (fluorone dyes) used to label groundwater to determine the rate and direction of flow and transport. Rhodamine dyes fluoresce and can be detected with a fluorometer.

\section{S}

sink See sinkhole

sinkhole [country of origin, United States] General terms for closed depressions. May be basin, funnel, or cylindrical shaped. See also closed depression; doline; swallet; swallow hole.

solution pipe A vertical cylindrical hole attributable to solution, often without surface expression, filled with debris, such as sand, clay, rock chips, and bones.

solution scarp Escarpment formed by more active solution of lower area or by corrosional undercutting of the base of the escarpment.

solution subsidence Any subsidence caused by solution of underlying rock but particularly the subsidence of parts of a formation into hollows or pockets of an immediately underlying soluble formation.

speleogenesis The varied processes by which caves are formed.

spring Any natural discharge of water from rock or soil onto the surface of the land or into a body of surface water.

subjacent karst Karst landscape in noncarbonate rocks due to presence of karstified rocks beneath the surface formation.

subsidence The lowering of the surface of the ground because of removal of support. Caused in karst areas by subterranean solution or collapse of caves. swallet [country of origin, United Kingdom] A place where water disappears underground in a limestone region. A swallow hole generally implies water loss in a closed depression or blind valley, whereas a swallet may refer to water loss into alluvium at a streambed, even though there is no depression.

swallow hole See swallet

\section{T}

travertine Calcium carbonate, light in color and generally concretionary and compact, deposited from solution in ground and surface waters. Extremely porous or cellular varieties are known as calcareous tufa, sinter, or spring deposit. Compact banded varieties, capable of taking a polish, are called onyx marble or cave onyx.

\section{V}

vadose water Water in the zone of aeration, above the zone of saturation (water table).

vug A small cavity in rock usually lined with crystals.

W

water table The upper boundary of an unconfined zone of saturation, along which the hydrostatic pressure is equal to the atmospheric pressure.

Z

zone of aeration The zone in permeable soil or rock that is above the zone saturated with water, the zone of vadose water.

zone of saturation The zone in permeable soil or rock that is saturated with water; the phreatic zone. 



\section{Appendix 1. Characteristics of Caves in New York}


Table 1.1. Characteristics of caves in New York, by county.

[USGS, U.S. Geological Survey; quad, topographic quadrangle; mi, mile; ft, foot; $\mathrm{ft} 3 / \mathrm{s}$, cubic foot per second; TCE, trichloroethene; <, less than]

\begin{tabular}{|c|c|c|c|c|c|c|c|}
\hline County & Geology & $\begin{array}{l}\text { Karst features } \\
\text { present }\end{array}$ & Cave size & $\begin{array}{l}\text { Cave fre- } \\
\text { quency }\end{array}$ & Cave hydrology & $\begin{array}{c}\text { Other solution- or } \\
\text { karst-related features }\end{array}$ & Comments $^{1}$ \\
\hline Albany & $\begin{array}{l}\text { Helderberg, } \\
\text { Onondaga } \\
\text { limestones, and } \\
\text { talus }\end{array}$ & $\begin{array}{l}\text { Sinkholes, solu- } \\
\text { tion channels, } \\
\text { springs, caves, } \\
\text { and caverns }\end{array}$ & $\begin{array}{l}\text { Mostly small, } \\
\text { some large } \\
\text { (long) cav- } \\
\text { erns present }\end{array}$ & Extensive & $\begin{array}{l}\text { Wet and season- } \\
\text { ally dry }\end{array}$ & - & $\begin{array}{l}\text { Clarksville } 7.5 \text {-minute USGS quad has } \\
\text { nearly } 170 \text { identifiable karst fea- } \\
\text { tures and this count does not include } \\
\text { solutionally-enlarged joints. The } \\
\text { overwhelming majority of the county's } \\
\text { caves are small. This high number } \\
\text { represents many small caves found } \\
\text { in isolated knolls and valleys formed } \\
\text { as the result of folding and faulting } \\
\text { commonly found throughout much of } \\
\text { the southern part of the county. In fact, } \\
\text { in sheer numbers, most of the county's } \\
\text { caves are found from Thacher State } \\
\text { Park and south. This is that part of the } \\
\text { county that shows increasing structural } \\
\text { complexity the farther south one goes, } \\
\text { entering what Marshak (1990) calls } \\
\text { the Hudson Valley fold-thrust belt. }\end{array}$ \\
\hline Allegany & No karst & - & - & - & - & - & \\
\hline Bronx & Inwood marble & $\begin{array}{l}\text { Caves (very small) } \\
\text { not verified, } \\
\text { possible solution } \\
\text { channels }\end{array}$ & Small & Uncommon & Unknown & - & \\
\hline Broome & Talus & $\begin{array}{l}\text { Caves possible but } \\
\text { not verified }\end{array}$ & Small & Uncommon & Unknown & - & \\
\hline Cattaraugus & $\begin{array}{l}\text { Fractured-rock } \\
\text { caves in con- } \\
\text { glomerates }\end{array}$ & $\begin{array}{l}\text { Fracture caves, un- } \\
\text { known solution } \\
\text { features }\end{array}$ & Very small & Uncommon & Dry & - & $\begin{array}{l}\text { Olean Rock City, Salamanca Rock City, } \\
\text { Thunder Rocks, Bear Cave Ledge }\end{array}$ \\
\hline Cayuga & $\begin{array}{l}\text { Onondaga } \\
\text { Limestone }\end{array}$ & $\begin{array}{l}\text { Sinkholes, solu- } \\
\text { tion channels, } \\
\text { springs, a few } \\
\text { caves (historic } \\
\text { reports) }\end{array}$ & Small & Present & $\begin{array}{l}\text { Unknown for } \\
\text { caves, solu- } \\
\text { tion channels } \\
\text { with variable } \\
\text { water levels. }\end{array}$ & - & $\begin{array}{l}\text { Robert W. Carroll Jr. reports sinkholes } \\
\text { in the Auburn area that during the } \\
\text { mid-1960s defied efforts to fill them. } \\
\text { [Study of contaminant plume flowing } \\
\text { downdip in the Onondaga Limestone, } \\
\text { from Auburn area to Union Springs } \\
\text { (Cayuga Lake), New York (Eckhardt } \\
\text { and others, 2011; U.S. Environmental } \\
\text { Protection Agency, 2019)]* }\end{array}$ \\
\hline Chautauqua & $\begin{array}{l}\text { Fractured-rock } \\
\text { caves in con- } \\
\text { glomerates }\end{array}$ & Fracture caves & Small & Present & Dry? & - & $\begin{array}{l}\text { Panama Rocks There are stories of sub- } \\
\text { merged limestone caves in Lake Erie, } \\
\text { but nothing has ever been verified. }\end{array}$ \\
\hline
\end{tabular}


Table 1.1. Characteristics of caves in New York, by county.-Continued

[USGS, U.S. Geological Survey; quad, topographic quadrangle; mi, mile; ft, foot; $\mathrm{ft} 3 / \mathrm{s}$, cubic foot per second; TCE, trichloroethene; <, less than]

\begin{tabular}{|c|c|c|c|c|c|c|c|}
\hline County & Geology & $\begin{array}{l}\text { Karst features } \\
\text { present }\end{array}$ & Cave size & $\begin{array}{l}\text { Cave fre- } \\
\text { quency }\end{array}$ & Cave hydrology & $\begin{array}{l}\text { Other solution- or } \\
\text { karst-related features }\end{array}$ & Comments $^{1}$ \\
\hline Chemung & No karst & - & - & - & - & - & \\
\hline Chenango & No karst & - & - & - & - & - & \\
\hline Clinton & $\begin{array}{l}\text { Talus, fracture } \\
\text { caves, lime- } \\
\text { stone of the } \\
\text { Chazy Group, } \\
\text { Trenton/Black } \\
\text { River Group } \\
\text { limestone, and } \\
\text { Beekmantown } \\
\text { Group }\end{array}$ & $\begin{array}{l}\text { Talus caves gener- } \\
\text { ally found in } \\
\text { gneiss }\end{array}$ & Small & Present & $\begin{array}{l}\text { Mostly dry, } \\
\text { Some } \\
\text { wet caves } \\
\text { adjacent to } \\
\text { and in Lake } \\
\text { Champlain }\end{array}$ & - & $\begin{array}{l}\text { On Valcour Island there are at least two } \\
\text { maze caves each exceeding } 400 \mathrm{ft} \\
\text { in length. The passages are typically } \\
\text { tear-drop in shape. These caves are at } \\
\text { lake level with } 85 \text { percent or more of } \\
\text { the passage below water. Indeed, there } \\
\text { is evidence for substantial karsti- } \\
\text { fication below water. Whether this } \\
\text { represents ongoing processes or are } \\
\text { remnants of lower lake levels is not } \\
\text { clear at this time. There are also some } \\
\text { fracture caves formed in the Potsdam } \\
\text { Sandstone in the area of Ausable } \\
\text { Chasm. }\end{array}$ \\
\hline Columbia & $\begin{array}{l}\text { Marble, possibly } \\
\text { limestone }\end{array}$ & $\begin{array}{l}\text { Marble caves, un- } \\
\text { known solution } \\
\text { features }\end{array}$ & Small & Present & Dry & - & $\begin{array}{l}\text { No bottom pond drains to marble karst } \\
\text { adjacent to pond. }\end{array}$ \\
\hline Cortland & No karst & - & - & - & - & - & \\
\hline Delaware & No karst & - & - & - & - & - & \\
\hline Dutchess & Marble & $\begin{array}{l}\text { Few caves, some } \\
\text { rock shelters, un- } \\
\text { known solution } \\
\text { features }\end{array}$ & Small & Present & Unknown & - & \\
\hline Erie & $\begin{array}{l}\text { Onondaga } \\
\text { Limestone, } \\
\text { Camillus shale } \\
\text { (gypsum) }\end{array}$ & $\begin{array}{l}\text { Sinkholes, solu- } \\
\text { tion channels, } \\
\text { springs, few } \\
\text { small caves }\end{array}$ & Small & Present & $\begin{array}{l}\text { Dry caves, solu- } \\
\text { tion channels } \\
\text { saturated, } \\
\text { flow to west }\end{array}$ & $\begin{array}{l}\text { Former gypsum } \\
\text { mines north of } \\
\text { the Onondaga } \\
\text { Limestone escarp- } \\
\text { ment may have } \\
\text { caused minimal } \\
\text { subsidence issues } \\
\text { as mine openings } \\
\text { collapse. }\end{array}$ & $\begin{array}{l}\text { Diversion of quarry discharge away from } \\
\text { nearby sinkhole caused extensive de- } \\
\text { watering of homeowner wells in 1980s } \\
\text { along closed depression-solution chan- } \\
\text { nel over an approximate 4-mi length } \\
\text { (Staubitz and Miller, 1987). Onondaga } \\
\text { Limestone is sometimes used to 'drain } \\
\text { wells' for surface runoff and shallow } \\
\text { soil dewatering.* }\end{array}$ \\
\hline
\end{tabular}


Table 1.1. Characteristics of caves in New York, by county.-Continued

[USGS, U.S. Geological Survey; quad, topographic quadrangle; mi, mile; ft, foot; $\mathrm{ft} 3 / \mathrm{s}$, cubic foot per second; TCE, trichloroethene; <, less than]

\begin{tabular}{|c|c|c|c|c|c|c|c|}
\hline County & Geology & $\begin{array}{l}\text { Karst features } \\
\text { present }\end{array}$ & Cave size & $\begin{array}{l}\text { Cave fre- } \\
\text { quency }\end{array}$ & Cave hydrology & $\begin{array}{l}\text { Other solution- or } \\
\text { karst-related features }\end{array}$ & Comments ${ }^{1}$ \\
\hline Essex & $\begin{array}{l}\text { Talus, marble, } \\
\text { fracture caves, } \\
\text { limestone? }\end{array}$ & $\begin{array}{l}\text { Talus caves, some } \\
\text { solution features }\end{array}$ & $\begin{array}{l}\text { General small } \\
\text { talus caves, } \\
\text { although a } \\
\text { few exceed } \\
1,000 \mathrm{ft} \\
\text { in length. } \\
\text { Few marble } \\
\text { caves, and } \\
\text { few fracture } \\
\text { caves }\end{array}$ & Extensive & Dry & - & $\begin{array}{l}\text { The longest known solutional caves are } \\
\text { Burroughs Cave }(2,000+\mathrm{ft}) \text { and Big } \\
\text { Loop Cave }(1,150 \mathrm{ft}) \text {. Burroughs Cave } \\
\text { is the longest known marble cave } \\
\text { in New York. There are some short } \\
\text { fracture caves (most are }<20 \mathrm{ft} \text { long) } \\
\text { in the county. Most notable is Pitchoff } \\
\text { Mountain Cave formed in anorthosite. } \\
\text { There are also a few fracture caves in } \\
\text { Potsdam Sandstone in the east part of } \\
\text { the county, near Lake Champlain. }\end{array}$ \\
\hline Franklin & $\begin{array}{l}\text { Talus, fracture } \\
\text { caves }\end{array}$ & $\begin{array}{l}\text { Unknown solution } \\
\text { features }\end{array}$ & Small & Present & Dry & - & \\
\hline Fulton & Talus, Limestone & $\begin{array}{l}\text { Some sinkholes, so- } \\
\text { lution channels, } \\
\text { springs }\end{array}$ & Small & Uncommon & Dry & - & $\begin{array}{l}\text { The Little Falls Dolomite and } \\
\text { Ordovician-aged limestones crop out } \\
\text { in the county, but no caves are known. }\end{array}$ \\
\hline Genesee & $\begin{array}{l}\text { Onondaga } \\
\text { Limestone, } \\
\text { Camillus shale } \\
\text { (gypsum) }\end{array}$ & $\begin{array}{l}\text { Sinkholes, solu- } \\
\text { tion channels, } \\
\text { springs, a few } \\
\text { small caves }\end{array}$ & Small & $\begin{array}{l}\text { Sinkholes, } \\
\text { solution } \\
\text { channels, } \\
\text { and springs } \\
\text { present, } \\
\text { caves un- } \\
\text { common }\end{array}$ & $\begin{array}{l}\text { Solution chan- } \\
\text { nels intermit- } \\
\text { tently wet }\end{array}$ & $\begin{array}{l}\text { The Camillus Shale } \\
\text { has a thin bed of } \\
\text { gypsum ( } 3 \text { to } 5 \mathrm{ft} \\
\text { thick) which has } \\
\text { been mined north } \\
\text { of the Onondaga } \\
\text { Escarpment. It has } \\
\text { been reported that } \\
\text { small solutional } \\
\text { conduits drained } \\
\text { into these mines } \\
\text { and some land- } \\
\text { surface subsidence } \\
\text { (bulk or sinkhole } \\
\text { subsidence fea- } \\
\text { tures) has also oc- } \\
\text { curred as the mine } \\
\text { openings collapse. }\end{array}$ & $\begin{array}{l}\text { One of the largest sinking streams in } \\
\text { New York, Oatka Creek, is found } \\
\text { there, and has a drainage area of } 139 \\
\text { mi. On the east side of the County the } \\
\text { Onondaga Limestone and other bed- } \\
\text { rock units have been displaced to the } \\
\text { north by the Clarendon-Linden Fault } \\
\text { and there are several karst springs } \\
\text { along and near the fault. [Also see } \\
\text { Reddy and Kappel (2010) for a study } \\
\text { of karst in the Onondaga Limestone in } \\
\text { Genesee County.]* }\end{array}$ \\
\hline
\end{tabular}


Table 1.1. Characteristics of caves in New York, by county.-Continued

[USGS, U.S. Geological Survey; quad, topographic quadrangle; mi, mile; ft, foot; $\mathrm{ft} 3 / \mathrm{s}$, cubic foot per second; TCE, trichloroethene; <, less than]

\begin{tabular}{|c|c|c|c|c|c|c|c|}
\hline County & Geology & $\begin{array}{c}\text { Karst features } \\
\text { present }\end{array}$ & Cave size & $\begin{array}{l}\text { Cave fre- } \\
\text { quency }\end{array}$ & Cave hydrology & $\begin{array}{c}\text { Other solution- or } \\
\text { karst-related features }\end{array}$ & Comments ${ }^{1}$ \\
\hline Greene & $\begin{array}{l}\text { Helderberg and } \\
\text { Onondaga } \\
\text { Limestones, } \\
\text { a few fissure } \\
\text { caves in Catskill } \\
\text { region in con- } \\
\text { glomerates }\end{array}$ & $\begin{array}{c}\text { Few sinkholes and } \\
\text { solution chan- } \\
\text { nels, some caves }\end{array}$ & Small & Present & Unknown & - & $\begin{array}{l}\text { These limestones are all found in the } \\
\text { Hudson Valley fold-thrust belt. The } \\
\text { rocks are largely folded and faulted } \\
\text { and are compressed in an east-west } \\
\text { direction. As a result, many of the } \\
\text { limestone caves are generally oriented } \\
\text { along the strike of the major faults or } \\
\text { down locally, in steeply dipping rock. }\end{array}$ \\
\hline Hamilton & $\begin{array}{l}\text { Marble, talus, and } \\
\text { fracture caves. } \\
\text { Limestone? }\end{array}$ & $\begin{array}{l}\text { Caves, mostly } \\
\text { short, in talus, } \\
\text { although some } \\
\text { may be solu- } \\
\text { tional. }\end{array}$ & Small & Present & Unknown & - & \\
\hline Herkimer & $\begin{array}{l}\text { Trenton- } \\
\text { Black River } \\
\text { Limestone, } \\
\text { marble, talus, } \\
\text { fracture, and } \\
\text { two tufa caves. }\end{array}$ & $\begin{array}{l}\text { Caves, generally } \\
\text { small, sinkholes, } \\
\text { short solution } \\
\text { channels }\end{array}$ & Small & Present & Unknown & - & $\begin{array}{l}\text { Of interest is the chyle hole. This feature, } \\
\text { a large occluded sink that takes a } \\
\text { stream, has given its name to similar } \\
\text { features in parts of Herkimer, Oneida, } \\
\text { and Otsego Counties. Thus, locals } \\
\text { often refer to sinks as chyle holes. The } \\
\text { Van Hornesville Tufa Caves are one of } \\
\text { two known groups of caves formed in } \\
\text { calcareous tufa in the State. }\end{array}$ \\
\hline Jefferson & $\begin{array}{l}\text { Trenton-Black } \\
\text { River Group } \\
\text { Limestone, } \\
\text { marble, talus } \\
\text { fracture caves } \\
\text { and two tufa } \\
\text { caves. }\end{array}$ & $\begin{array}{l}\text { Caves, solu- } \\
\text { tion channels, } \\
\text { sinkholes, losing/ } \\
\text { gaining streams }\end{array}$ & $\begin{array}{l}\text { Mostly small, } \\
\text { a few larger } \\
\text { (long) cav- } \\
\text { erns present }\end{array}$ & Common & $\begin{array}{l}\text { Intermittently to } \\
\text { nearly always } \\
\text { wet }\end{array}$ & - & $\begin{array}{l}\text { All but a few of these caves are formed } \\
\text { in the Ordovician-aged Trenton-Black } \\
\text { River Group limestones. The excep- } \\
\text { tion is Natural Bridge Caverns formed } \\
\text { in pre-Cambrian marbles (often called } \\
\text { the Grenville Marble). At } 2,000 \mathrm{ft} \text {, this } \\
\text { is the longest known marble cave in } \\
\text { New York. }\end{array}$ \\
\hline Kings & No karst & - & - & - & - & - & \\
\hline Lewis & $\begin{array}{l}\text { Trenton-Black } \\
\text { River Group } \\
\text { limestone, } \\
\text { marble }\end{array}$ & $\begin{array}{l}\text { Solution channels, } \\
\text { some caves }\end{array}$ & $\begin{array}{l}\text { Small cases } \\
\text { mostly }\end{array}$ & Present & Unknown & - & $\begin{array}{l}\text { There is one known large cave-Drought } \\
\text { Cave }(2,000 \mathrm{ft}) \text { - close to the Oneida } \\
\text { County line just north of Boonville. } \\
\text { This low number may be because few } \\
\text { people are looking. The Sugar River } \\
\text { sinks into the its limestone channel. }\end{array}$ \\
\hline
\end{tabular}


Table 1.1. Characteristics of caves in New York, by county.-Continued

[USGS, U.S. Geological Survey; quad, topographic quadrangle; mi, mile; ft, foot; $\mathrm{ft} 3 / \mathrm{s}$, cubic foot per second; TCE, trichloroethene; <, less than]

\begin{tabular}{|c|c|c|c|c|c|c|c|}
\hline County & Geology & $\begin{array}{l}\text { Karst features } \\
\text { present }\end{array}$ & Cave size & $\begin{array}{l}\text { Cave fre- } \\
\text { quency }\end{array}$ & Cave hydrology & $\begin{array}{l}\text { Other solution- or } \\
\text { karst-related features }\end{array}$ & Comments ${ }^{1}$ \\
\hline Livingston & $\begin{array}{l}\text { Onondaga } \\
\text { Limestone }\end{array}$ & $\begin{array}{l}\text { Solution chan- } \\
\text { nels, sinkholes, } \\
\text { springs, losing/ } \\
\text { gaining streams }\end{array}$ & Unknown & Uncommon & Unknown & $\begin{array}{l}\text { A few phantom lakes } \\
\text { and ponds occur } \\
\text { in the Onondaga } \\
\text { Limestone where it } \\
\text { crops out near land } \\
\text { surface - variable } \\
\text { solution channel } \\
\text { capacities cause } \\
\text { these intermittent } \\
\text { water bodies to } \\
\text { quickly appear and } \\
\text { disappear. }\end{array}$ & $\begin{array}{l}\text { Karst is found near Caledonia where one } \\
\text { of the State's largest karst springs, Big } \\
\text { Spring, is located. It has a low flow of } \\
5 \mathrm{ft} 3 / \mathrm{s} \text {. [A railroad tank car derailment } \\
\text { in } 1970 \text { caused a large amount of TCE } \\
\text { to flow into the Onondaga Limestone } \\
\text { and flowed eastward, but it was never } \\
\text { detected (at any level of concern) in } \\
\text { Big Spring which feeds a fish hatchery } \\
\text { (U.S. Environmental Protection } \\
\text { Agency, 2017)..* }\end{array}$ \\
\hline Madison & $\begin{array}{l}\text { Helderberg and } \\
\text { Onondaga } \\
\text { Limestone }\end{array}$ & $\begin{array}{l}\text { Solution chan- } \\
\text { nels, springs, } \\
\text { cascading water } \\
\text { in wells, losing/ } \\
\text { gaining streams }\end{array}$ & None known & Uncommon & Unknown & - & $\begin{array}{l}\text { Some caves are reported near } \\
\text { Chittenango/Chittenango Falls State } \\
\text { Park. [Cascading water in drinking } \\
\text { water wells has caused groundwater/ } \\
\text { surface water interaction, causing } \\
\text { drinking-water well, water-quality } \\
\text { issues.] }\end{array}$ \\
\hline Monroe & $\begin{array}{l}\text { Onondaga } \\
\text { Limestone, } \\
\text { Camillus shale } \\
\text { (gypsum) }\end{array}$ & $\begin{array}{l}\text { Solution chan- } \\
\text { nels, sinkholes, } \\
\text { springs }\end{array}$ & None known & Uncommon & Unknown & $\begin{array}{l}\text { Gypsum mines north } \\
\text { of the Onondaga } \\
\text { Limestone escarp- } \\
\text { ment have caused } \\
\text { subsidence issues, } \\
\text { such as in Monroe } \\
\text { County's Oatka } \\
\text { Creek Park. }\end{array}$ & \\
\hline Montgomery & $\begin{array}{l}\text { Dolostone, lime- } \\
\text { stone }\end{array}$ & $\begin{array}{l}\text { Fractured (faulted) } \\
\text { rock }\end{array}$ & Small & Uncommon & Unknown & - & \\
\hline Nassau & No karst & - & - & - & - & - & \\
\hline $\begin{array}{l}\text { New York } \\
\text { (Manhattan) }\end{array}$ & Inwood marble & $\begin{array}{l}\text { Very small caves, } \\
\text { unknown karst } \\
\text { features }\end{array}$ & Small & Uncommon & Unknown & $\begin{array}{l}\text { The type locality of } \\
\text { the Inwood Marble } \\
\text { is Inwood Park at } \\
\text { the north end of } \\
\text { Manhattan Island. } \\
\text { There are three } \\
\text { small caves here } \\
\text { and two in Central } \\
\text { Park. }\end{array}$ & \\
\hline
\end{tabular}


Table 1.1. Characteristics of caves in New York, by county.-Continued

[USGS, U.S. Geological Survey; quad, topographic quadrangle; mi, mile; ft, foot; $\mathrm{ft} 3 / \mathrm{s}$, cubic foot per second; TCE, trichloroethene; <, less than]

\begin{tabular}{|c|c|c|c|c|c|c|c|}
\hline County & Geology & $\begin{array}{l}\text { Karst features } \\
\text { present }\end{array}$ & Cave size & $\begin{array}{l}\text { Cave fre- } \\
\text { quency }\end{array}$ & Cave hydrology & $\begin{array}{c}\text { Other solution- or } \\
\text { karst-related features }\end{array}$ & Comments ${ }^{1}$ \\
\hline Niagara & $\begin{array}{l}\text { Lockport } \\
\text { Dolostone }\end{array}$ & $\begin{array}{l}\text { Some sinkholes, } \\
\text { solution chan- } \\
\text { nels, and springs } \\
\text { known, a few } \\
\text { caves }\end{array}$ & Small & Uncommon & Dry? & $\begin{array}{l}\text { The few karst features } \\
\text { that are found in the } \\
\text { upper weathered } \\
\text { Lockport Dolostone } \\
\text { are usually associ- } \\
\text { ated with solution } \\
\text { channels: some } \\
\text { vertical, some flow- } \\
\text { ing along discrete } \\
\text { bedding planes } \\
\text { in the Lockport } \\
\text { Dolostone. The } \\
\text { large caves ap- } \\
\text { pear to be found } \\
\text { near the Lockport } \\
\text { Escarpment. }\end{array}$ & $\begin{array}{l}\text { Lockport Dolostone unit has some large } \\
\text { caves on either side of the Niagara } \\
\text { River gorge and along its escarpment. } \\
\text { Lockport Cave may have had as much } \\
\text { as } 2 \text { mi of passage, but the cave has } \\
\text { not been found in recent times. Of the } \\
\text { approximately } 40 \text { caves, } 7 \text { are histori- } \\
\text { cally well documented, but have since } \\
\text { been destroyed. Five other caves are } \\
\text { rumored or lost. }\end{array}$ \\
\hline Oneida & $\begin{array}{l}\text { Trenton Limestone } \\
\text { (north) } \\
\text { Helderberg- } \\
\text { Onondaga } \\
\text { Limestone } \\
\text { (south) and tufa }\end{array}$ & $\begin{array}{l}\text { Sinkholes, solution } \\
\text { channels and } \\
\text { springs, but few } \\
\text { caves }\end{array}$ & Small & Uncommon & Unknown & $\begin{array}{l}\text { There is a calcareous } \\
\text { tufa deposit north- } \\
\text { west of Waterville } \\
\text { at Forge Hollow } \\
\text { that contains one of } \\
\text { two known groups } \\
\text { of New York caves } \\
\text { formed in such ma- } \\
\text { terial. The Unadilla } \\
\text { River rises from a } \\
\text { limestone spring. } \\
\text { There are reports } \\
\text { of caves upstream } \\
\text { from Pixley Falls } \\
\text { State Park, where } \\
\text { the Lansing Kill ap- } \\
\text { parently sinks into } \\
\text { a fissure resurging } \\
\text { 0.5 mi downstream. }\end{array}$ & \\
\hline
\end{tabular}


Table 1.1. Characteristics of caves in New York, by county.-Continued

[USGS, U.S. Geological Survey; quad, topographic quadrangle; mi, mile; ft, foot; $\mathrm{ft} 3 / \mathrm{s}$, cubic foot per second; TCE, trichloroethene; <, less than]

\begin{tabular}{|c|c|c|c|c|c|c|c|}
\hline County & Geology & $\begin{array}{c}\text { Karst features } \\
\text { present }\end{array}$ & Cave size & $\begin{array}{l}\text { Cave fre- } \\
\text { quency }\end{array}$ & Cave hydrology & $\begin{array}{c}\text { Other solution- or } \\
\text { karst-related features }\end{array}$ & Comments ${ }^{1}$ \\
\hline Onondaga & $\begin{array}{l}\text { Onondaga and } \\
\text { Manlius } \\
\text { Limestone, } \\
\text { Camillus Shale } \\
\text { (gypsum) }\end{array}$ & $\begin{array}{l}\text { Few sinkholes, } \\
\text { minor caves, } \\
\text { fracture- } \\
\text { openings, evapo- } \\
\text { rite subsidence }\end{array}$ & Very small & Uncommon & Unknown & $\begin{array}{l}\text { One small cave } \\
\text { under I- } 81 \text { in } \\
\text { south Syracuse } \\
\text { documented by } \\
\text { New York State } \\
\text { Department of } \\
\text { Transportation, and } \\
\text { several fracture- } \\
\text { opening caves } \\
\text { adjacent to Rock } \\
\text { Cut Road quarry } \\
\text { escarpment. }\end{array}$ & $\begin{array}{l}\text { See Robertson (1970) for informa- } \\
\text { tion on caves in Onondaga County. } \\
\text { [Subsidence of about } 30 \mathrm{ft} \text { attributed } \\
\text { to gypsum dissolution (Phillips, 1955). } \\
\text { City infrastructure study also looked } \\
\text { at water main breaks in relation to } \\
\text { several anthropogenic factors and } \\
\text { gypsum. Engineering studies have } \\
\text { documented infrastructure subsidence } \\
\text { in the Camillus region of the City.]* } \\
\text { French (1860) suggests gypsum caves } \\
\text { near Jamesville. }\end{array}$ \\
\hline Ontario & $\begin{array}{l}\text { Onondaga } \\
\text { Limestone }\end{array}$ & $\begin{array}{l}\text { Few sinkholes, } \\
\text { solution channels } \\
\text { noted }\end{array}$ & None known & Uncommon & Unknown & & \\
\hline Orange & $\begin{array}{l}\text { Marble, } \\
\text { Helderberg } \\
\text { and Onondaga } \\
\text { Limestone }\end{array}$ & $\begin{array}{l}\text { Some solution } \\
\text { features may be } \\
\text { present }\end{array}$ & Small & Uncommon & Unknown & & $\begin{array}{l}\text { The best-known caves are probably } \\
\text { Dutchess Quarry Caves } 1 \text { through } 9 . \\
\text { These are actually only four small } \\
\text { caves, but all have great archeological } \\
\text { significance. }\end{array}$ \\
\hline Orleans & No karst & - & - & - & - & - & \\
\hline Oswego & No karst & - & - & - & - & - & \\
\hline Otsego & $\begin{array}{l}\text { Helderberg and } \\
\text { Onondaga } \\
\text { Limestone, and } \\
\text { facture openings } \\
\text { in shale }\end{array}$ & $\begin{array}{l}\text { Sinkholes, solu- } \\
\text { tion channels, } \\
\text { springs, possible } \\
\text { losing/gaining } \\
\text { streams }\end{array}$ & $\begin{array}{l}\text { Generally } \\
\text { small }\end{array}$ & Present & Mixed & - & $\begin{array}{l}\text { The Helderberg and Onondaga lime- } \\
\text { stones are exposed in irregular bands } \\
\text { along the northern edge of the county. } \\
\text { There is much karst to be explored } \\
\text { and one suspects that the lack of caves } \\
\text { is from a lack of looking and nothing } \\
\text { more. Summit Lake is fed by some } \\
\text { large karst springs to the east which } \\
\text { resurge at the base of the Onondaga } \\
\text { limestone. Two fracture caves formed } \\
\text { in shale near Cooperstown. }\end{array}$ \\
\hline Putnam & Marble & $\begin{array}{l}\text { Unknown solution } \\
\text { features }\end{array}$ & Very small & Uncommon & Unknown & - & $\begin{array}{l}\text { A scattering of marble slivers in the } \\
\text { Taconic mélange are found through- } \\
\text { out Putnam County though they are } \\
\text { more common in the eastern half of } \\
\text { the county. None of the } 10 \text { or so small } \\
\text { caves are notable. }\end{array}$ \\
\hline Queens & No karst & - & - & - & - & - & \\
\hline
\end{tabular}


Table 1.1. Characteristics of caves in New York, by county.-Continued

[USGS, U.S. Geological Survey; quad, topographic quadrangle; mi, mile; ft, foot; $\mathrm{ft} 3 / \mathrm{s}$, cubic foot per second; TCE, trichloroethene; <, less than]

\begin{tabular}{|c|c|c|c|c|c|c|c|}
\hline County & Geology & $\begin{array}{c}\text { Karst features } \\
\text { present }\end{array}$ & Cave size & $\begin{array}{l}\text { Cave fre- } \\
\text { quency }\end{array}$ & Cave hydrology & $\begin{array}{c}\text { Other solution- or } \\
\text { karst-related features }\end{array}$ & Comments ${ }^{1}$ \\
\hline Rensselaer & $\begin{array}{l}\text { Marble, tectonic } \\
\text { fracture }\end{array}$ & $\begin{array}{l}\text { Unknown solution } \\
\text { features }\end{array}$ & Very small & Uncommon & Unknown & - & $\begin{array}{l}\text { Snow Hole is a small tectonic cave } \\
\text { formed in slate and phyllite. It gener- } \\
\text { ally contains snow and ice well into } \\
\text { summer. Country Club Cave is a } \\
\text { gravity-slip block cave formed in } \\
\text { shale. }\end{array}$ \\
\hline Richmond & No karst & - & - & - & - & - & \\
\hline Rockland & $\begin{array}{l}\text { Marble, fracture } \\
\text { caves }\end{array}$ & $\begin{array}{l}\text { Unknown solution } \\
\text { features }\end{array}$ & Very small & Uncommon & Unknown & - & $\begin{array}{l}\text { Rockland includes some marble outcrops } \\
\text { and a few small caves. The best- } \\
\text { known caves in the county, however, } \\
\text { are small fissure caves formed in igne- } \\
\text { ous and other metamorphic rocks. }\end{array}$ \\
\hline Saint Lawrence & $\begin{array}{l}\text { Talus, marble, } \\
\text { Potsdam sand- } \\
\text { stone (fracture) } \\
\text { caves }\end{array}$ & $\begin{array}{l}\text { Sinkholes, some so- } \\
\text { lution channels, } \\
\text { springs }\end{array}$ & Small & Common & Unknown & - & $\begin{array}{l}\text { The predominant cave type in the } \\
\text { county is talus, with about } 70 \text { known } \\
\text { solutional caves, and there are fracture } \\
\text { caves in the Potsdam Sandstone in the } \\
\text { northern part of the county. }\end{array}$ \\
\hline Saratoga & $\begin{array}{l}\text { Beekmantown } \\
\text { Group } \\
\text { Limestone, } \\
\text { dolostone }\end{array}$ & $\begin{array}{l}\text { Few sinkholes, } \\
\text { some solution } \\
\text { features }\end{array}$ & Very small & Uncommon & Unknown & - & $\begin{array}{l}\text { All known karst lie in the Ordovician- } \\
\text { aged limestones that ring the } \\
\text { Adirondacks. There is karst in } \\
\text { Saratoga Springs and stories about } \\
\text { caves in Congress Park and under } \\
\text { the new Skidmore Campus. Two new } \\
\text { cave discoveries have come to light } \\
\text { between Saratoga and Glens Falls, and } \\
\text { others west of Saratoga. }\end{array}$ \\
\hline Schenectady & $\begin{array}{l}\text { Dolostone, lime- } \\
\text { stone }\end{array}$ & $\begin{array}{l}\text { Fractured (faulted) } \\
\quad \text { rock }\end{array}$ & Small & Uncommon & Unknown & - & \\
\hline
\end{tabular}


Table 1.1. Characteristics of caves in New York, by county.-Continued

[USGS, U.S. Geological Survey; quad, topographic quadrangle; mi, mile; ft, foot; $\mathrm{ft} 3 / \mathrm{s}$, cubic foot per second; TCE, trichloroethene; <, less than]

\begin{tabular}{|c|c|c|c|c|c|c|c|}
\hline County & Geology & $\begin{array}{c}\text { Karst features } \\
\text { present }\end{array}$ & Cave size & $\begin{array}{l}\text { Cave fre- } \\
\text { quency }\end{array}$ & Cave hydrology & $\begin{array}{c}\text { Other solution- or } \\
\text { karst-related features }\end{array}$ & Comments 1 \\
\hline Schoharie & $\begin{array}{c}\text { Helderberg and } \\
\text { Onondaga } \\
\text { Limestone }\end{array}$ & $\begin{array}{l}\text { Many sinkholes, so- } \\
\text { lution channels, } \\
\text { springs, caves } \\
\text { and caverns, } \\
\text { losing/gaining } \\
\text { streams }\end{array}$ & Many lengths & Extensive & Mixed & - & $\begin{array}{l}\text { There are three major cave areas in } \\
\text { the county: the Cobleskill Plateau, } \\
\text { Terrace Mountain, and Barton Hill. } \\
\text { The Cobleskill Plateau is bounded on } \\
\text { the south by the Cobleskill Creek, on } \\
\text { the east by the Schoharie Creek, on } \\
\text { the north by the Helderberg escarp- } \\
\text { ment, and on the west by the younger } \\
\text { Devonian formations, most notably } \\
\text { the Esopus Shale. There is a fourth } \\
\text { area that will likely yield large caves } \\
\text { in the future, but now has only a few } \\
\text { small caves. The area is bounded on } \\
\text { the north and west by Kings Creek, } \\
\text { on the south by the Fox Creek, and on } \\
\text { the east by the Albany County line. In } \\
\text { the northwest corner of the county are } \\
\text { sinkholes thousands of feet across that } \\
\text { have yet to be checked out. }\end{array}$ \\
\hline
\end{tabular}

$\begin{array}{ll}\text { Schuyler } & \text { No karst } \\ \text { Seneca } & \text { No karst } \\ \text { Steuben } & \text { No karst } \\ \text { Suffolk } & \text { No karst } \\ \text { Sullivan } & \text { Limestone }\end{array}$

Tioga

Tompkins
No karst

Tully Limestone/ Moscow shale
Solution channels
at base of Tully

Limestone
Small

$$
\text { - }
$$

Unknown solution features

One long cave

Uncommon

Unknown

Uncommon

Seasonally wet

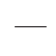

$-$

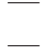

-

-

Limestone is found only along the southeast edge of Sullivan County. In that relatively small, steeply dipping exposure there is one large cave: Surprise or Mystery Cave with 9,975 $\mathrm{ft}$ of passage.

The Tully Limestone crops out north of Ithaca. The caves, which are generally joint-controlled, are formed at the contact between the Tully limestone and the underlying Moscow shale with the majority of the passage in the shale. [Likely other Tully/Moscow caves are present where this contact is exposed along the edges of the Finger Lakes.]* 
Table 1.1. Characteristics of caves in New York, by county.-Continued

[USGS, U.S. Geological Survey; quad, topographic quadrangle; mi, mile; ft, foot; $\mathrm{ft} 3 / \mathrm{s}$, cubic foot per second; TCE, trichloroethene; <, less than]

\begin{tabular}{|c|c|c|c|c|c|c|c|}
\hline County & Geology & $\begin{array}{l}\text { Karst features } \\
\text { present }\end{array}$ & Cave size & $\begin{array}{l}\text { Cave fre- } \\
\text { quency }\end{array}$ & Cave hydrology & $\begin{array}{c}\text { Other solution- or } \\
\text { karst-related features }\end{array}$ & Comments $^{1}$ \\
\hline Ulster & $\begin{array}{l}\text { Helderberg and } \\
\text { Onondaga } \\
\text { Limestone, } \\
\text { talus, fracture } \\
\text { caves }\end{array}$ & $\begin{array}{l}\text { Unknown solution } \\
\text { features }\end{array}$ & Mostly small & Present & Seasonally wet & - & $\begin{array}{l}\text { The Helderberg and Onondaga lime- } \\
\text { stones crop out as bands that run south } \\
\text { to Kingston and then southwest until } \\
\text { they leave the county near Ellenville. } \\
\text { In the area from Saugerties through } \\
\text { Kingston and down beyond Hurley, } \\
\text { the beds are highly folded and faulted. } \\
\text { To the southwest the severe defor- } \\
\text { mation ceases, but the beds are still } \\
\text { steeply dip to the northwest. The talus } \\
\text { and fissure caves are formed in the } \\
\text { Shawangunk Grit. }\end{array}$ \\
\hline Warren & Marble, talus & $\begin{array}{l}\text { Unknown solution } \\
\text { features }\end{array}$ & Small & Present & Unknown & - & $\begin{array}{l}\text { Warren County's caves are half solution- } \\
\text { al and half talus. As with the counties } \\
\text { east of the Hudson, Warren County } \\
\text { has isolated lenses of marble in which } \\
\text { caves have formed. In the southeast } \\
\text { corner of the county there is lime- } \\
\text { stone, but no caves are reported. }\end{array}$ \\
\hline Washington & $\begin{array}{l}\text { Marble, talus, } \\
\text { limestone(?) }\end{array}$ & $\begin{array}{l}\text { Unknown solution } \\
\text { features }\end{array}$ & Small & Uncommon & Unknown & - & \\
\hline Wayne & No karst & - & - & - & - & - & \\
\hline Westchester & Marble, talus & $\begin{array}{l}\text { Unknown solution } \\
\text { features }\end{array}$ & Small & Uncommon & Unknown & - & $\begin{array}{l}\text { A scattering of marble slivers in the } \\
\text { Taconic mélange are found throughout } \\
\text { Westchester County though they are } \\
\text { more common in the eastern half of } \\
\text { the county. }\end{array}$ \\
\hline Wyoming & No karst & - & - & - & - & - & \\
\hline Yates & No karst & - & - & - & - & - & \\
\hline
\end{tabular}

${ }^{1}$ Comments are from Thom Engle of the Northeastern Cave Conservancy and the National Speleological Society, except where indicated by an asterisk; comments with an asterisk are by William M. Kappel. 


\section{References Cited}

Eckhardt, D.A., Williams, J.H., and Anderson, J.A., 2011, Geophysical, stratigraphic, and flow-zone logs of selected wells in Cayuga County, New York, 2001-2011: U.S. Geological Survey Open-File Report 2011-1319, 13 p. [Also available at https://doi.org/10.3133/ofr20111319.]

French, J.H., 1860, Historical and statistical gazetteer of New York State-A comprehensive view of the geography, geology, and general history of the state: Syracuse, N.Y., R.P. Smith Publisher, 810 p.

Marshak, S., 1990, Structural geology of Silurian and Devonian strata in the mid-Hudson Valley, New YorkFold-thrust belt tectonics in miniature: New York State Museum Map and Chart Series 51, 66 p.

Phillips, J.S., 1955, Origin and significance of subsidence structures in carbonate rocks overlying Silurian evaporites in Onondaga County, central New York: Syracuse, Syracuse University, master's thesis, $142 \mathrm{p}$.

Reddy, J.E., and Kappel, W.M., 2010, Compilation of existing hydrogeologic and geospatial data for the assessment of focused recharge to the carbonate-rock aquifer in Genesee County, New York: U.S. Geological Survey Scientific Investigations Map 3132, 17 p., 20 sheets. [Also available at https://doi.org/10.3133/sim3132.]
Robertson, S., 1970, Caves in Onondaga County, New York: The Northeastern Caver, v. 2, no. 4, p. 31-33.

Staubitz, W.W., and Miller, T.S., 1987, Geology and hydrology of the Onondaga aquifer in eastern Erie County, New York; with emphasis on ground-water-level declines since 1982: U.S. Geological Survey Water-Resources Investigations Report 86-4317, 50 p., 4 pls. [Also available at https://doi.org/10.3133/wri864317.]

U.S. Environmental Protection Agency, 2017, Lehigh valley railroad, Le Roy, New York: U.S. Environmental Protection Agency Superfund website, accessed April 13, 2020, at https://cumulis.epa.gov/supercpad/cursites/csitinfo.cfm? $\mathrm{id}=0203481$.

U.S. Environmental Protection Agency, 2019, Cayuga groundwater contamination site, Union Springs, NY: U.S. Environmental Protection Agency Superfund website, accessed June 2019 at https://cumulis.epa.gov/supercpad/ cursites/csitinfo.cfm?id=0204289. 
For more information about this report, contact: Director, New York Water Science Center

U.S. Geological Survey

425 Jordan Road

Troy, NY 12180-8349

dc_ny@usgs.gov

(518) 285-5602

or visit our website at

https://www.usgs.gov/centers/ny-water

Publishing support provided by the Pembroke Publishing Service Center 


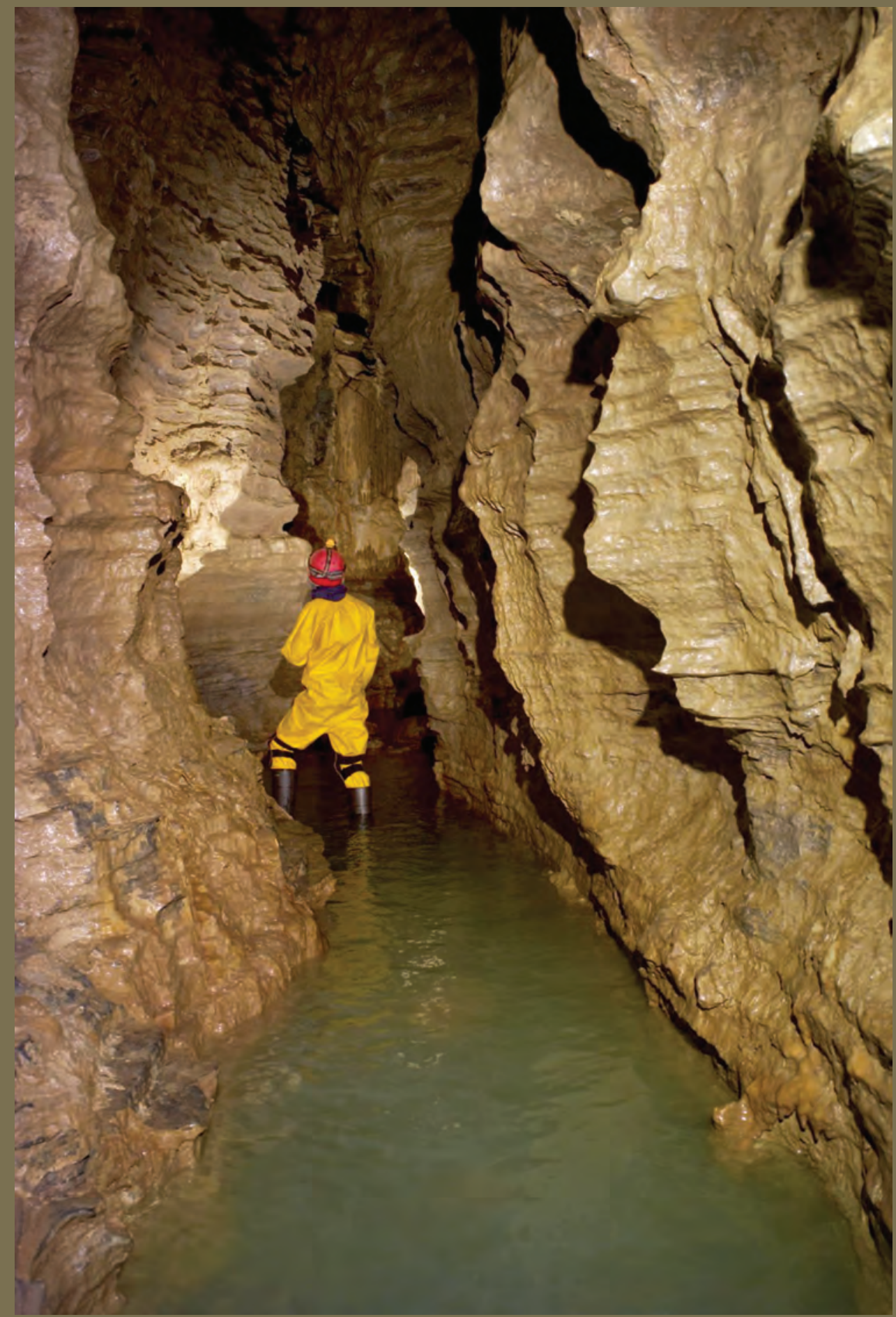

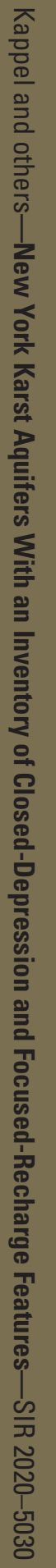

